University of Rhode Island

DigitalCommons@URI

Open Access Master's Theses

1991

\title{
An Inventory of Non-Point Pollution Sources on the Central South Branch of the Pawtuxet River
}

Latimer William Spinney IV

University of Rhode Island

Follow this and additional works at: https://digitalcommons.uri.edu/theses

\section{Recommended Citation}

Spinney, Latimer William IV, "An Inventory of Non-Point Pollution Sources on the Central South Branch of the Pawtuxet River" (1991). Open Access Master's Theses. Paper 726.

https://digitalcommons.uri.edu/theses/726

This Thesis is brought to you for free and open access by DigitalCommons@URI. It has been accepted for inclusion in Open Access Master's Theses by an authorized administrator of DigitalCommons@URI. For more information, please contact digitalcommons-group@uri.edu. 


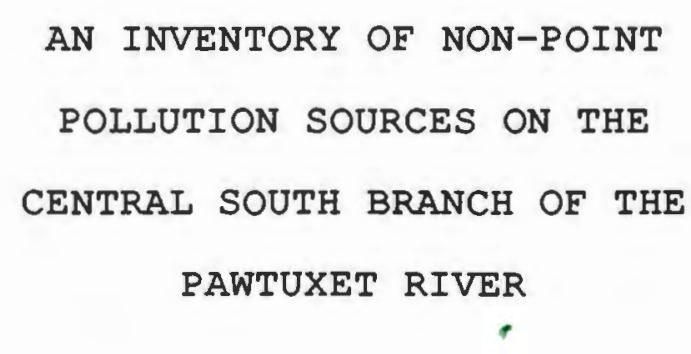

BY

LATIMER WILLIAM SPINNEY IV

A RESEARCH PROJECT SUBMITTED IN

PARTIAL FULFILLMENT OF THE REQUIREMENTS

FOR THE DEGREE AND MASTER OF

COMMUNITY PLANNING

THE UNIVERSITY OF RHODE ISLAND

1991 


\section{MASTER OF COMMUNITY PLANNING RESEARCH PROJECT \\ $O F$}

LATIMER WILIIAM SPINNEY IV

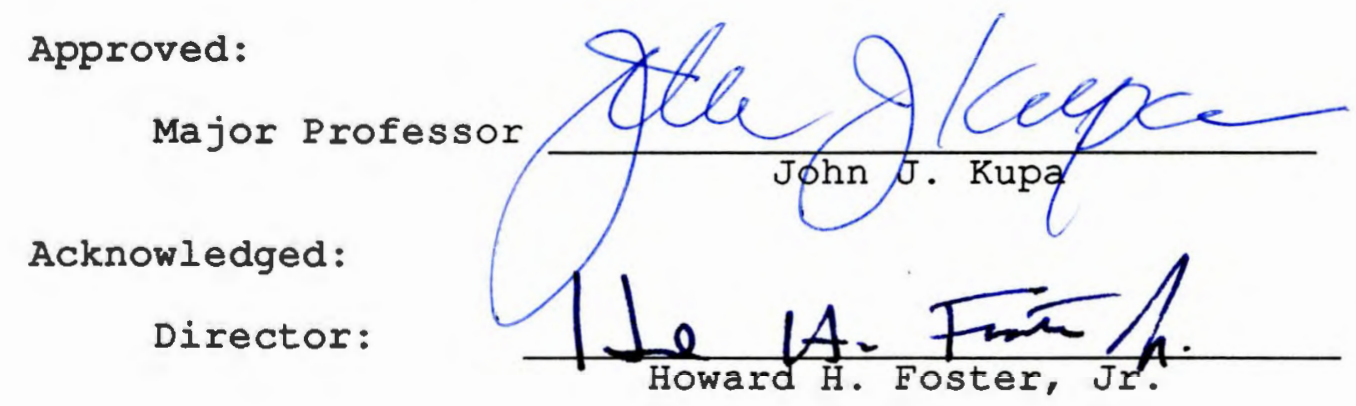




\section{ABSTRACT}

Water quality protection and preservation have, within the last decade, become imperative functions of local, state and federal governments. This focus has brought to light, newly revealed forms of water pollution. Nonpoint source pollution has become one of the major sources of pollutants. Nonpoint source pollution is a generic term for pollutants that come from individual sewage disposal systems, erosion and sediment, stormwater runoff, road deicing practices and fertilizer and pesticide use, to name a few.

The study area of this report consists of the portion of the south branch of the Pawtuxet River from South Main Street to Laurel Avenue and the surrounding sub-drainage basins. This is the section of the south branch if the River where the water quality classification changes from Class B to Class C.

A great number of reports have been written about water quality throughout the state, nonpoint source pollution and the Pawtuxet River, but none them focus on this section of the river.

This study focuses on a specific portion of the river where a worsening water quality problem exists. The report discusses facts and reasons for the water quality problem as it relates to the types nonpoint source pollution and offers solutions and recommendations for possibly alleviating the problem. The recommendations call for the development of best management practices or BMP's to alleviate the nonpoint source pollution problem. Some of these BMP's include: 
- Establishing wastewater management districts throughout the Town of Coventry.

- Establishing vegetative buffer strips along the banks of the River.

- Creating retention, detention or infiltration basins to filter pollutants from storm runoff.

- Establishing sewer lines throughout the eastern portion of the Town to alleviate the environmental strain caused by ISDS failure.

- Establishing programs that inform and educate the public about the River and its problems.

If implemented, these strategies would effectively reduce the amount of nonpoint source pollutants that enter the River, thereby improving its water quality. The process of achieving improved water quality on the Pawtuxet River involves not only the efforts of federal, state and local agencies but also the cooperation of private interest groups and the general public. 


\section{ACKNOWLEDGEMENTS}

I would like to first thank my parents for talking me into going to graduate school. Additionally, I would like to thank Jack McGillivray from the Pawtuxet River Authority for being extremely patient and for loaning me a number of documents that were very useful for the completion of this study. I would also like to thank John Kupa and Farhad Atash for assisting me along the way, without their help I wouldn't have finished the program sane. 


\section{TABLE OF CONTENTS}

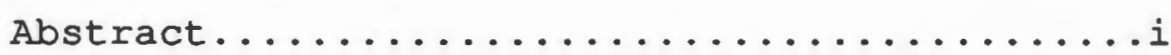

Acknowledgement..........................

List of Figures.....................

\section{Chapter}

Title

Page

1

Introduction ......................

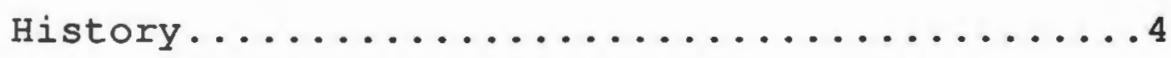

Topography.......................

Surface water Resources.................

Ground Water Resources....................... 10

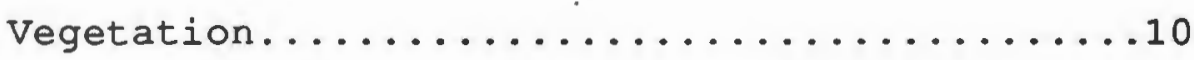

- Symbols For Vegetation..............10

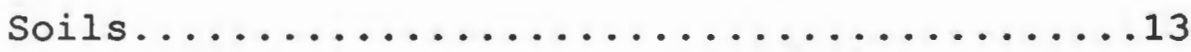

Individual Sewage Disposal systems (ISDS)....19

- Problem Areas.....................23

- Sewer Possibilities................24

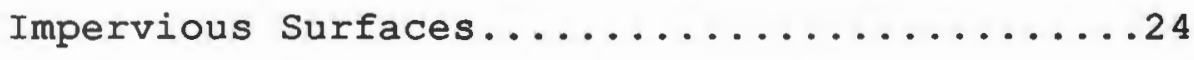

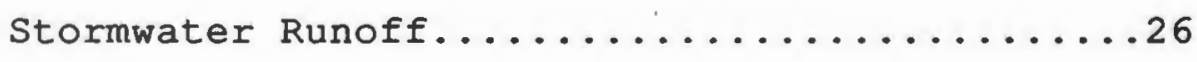

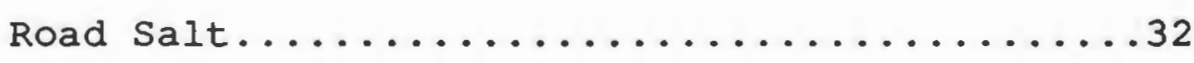

- Salt storage..........................

Debris Inventory........................

2 Current water Quality Review.................. 
3 Current Management Strategies

And Recommendations.....................43

- Stormwater Management..............45

- Individual Sewage Disposal System.....54

- Road Salt......................55

- Impervious Surfaces...............56

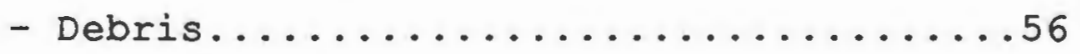

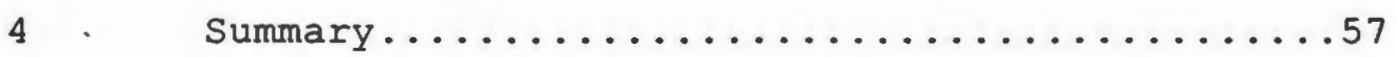

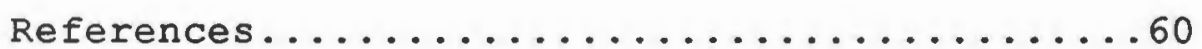

Appendix......................64

- Wastewater Management Districts......665

- Picture of Debris..................111

- Pollutant Load Maps................113

- Developing a Small Community Sewage Facility Through a Municipal

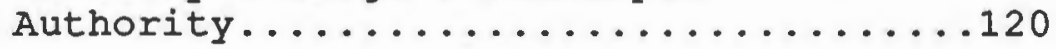




\section{IIST OF FIGURES}

Chapter Figure

1

1.1

1.2

1.3

1.4

1.5

1.6

1.7

1.8

1.9

1.10

1.11

1.12

1.13

1.14

1.15

3
Title

Page

State Watershed Map................

Study Area Map...............

Topography .................

Surface water Resources..........9

Groundwater Resources............11

Vegetation Types..................12

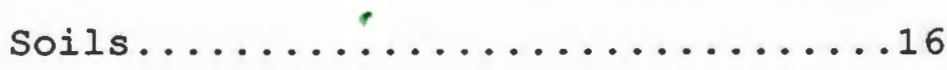

Soils with Severe ISDS Constraints

Limitations......................

Development Constraints Map........18

Diagram of A Typical Domestic

Septic Tank System.............22

Municipal Sewerage Needs.........25

Estimated Percent Impervious Land

In The Study Area..............27

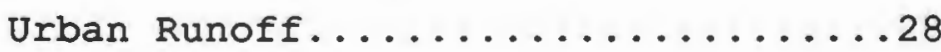

Storm Drain Systems In The Town of Coventry...........................

Debris Inventory Map.............35

3.1 Buffer Designation Model Overview...47

3.2 Special Conditions Evaluation.....48

3.3 Restrictions on BMP' $^{\prime} . \ldots \ldots . . \ldots 50$

3.4 BMP Benefits..................

3.5 BMP Pollutant Removal..........52

$3.6 \quad$ BMP Amenities............... 53 
CHA P T R ONE 


\section{INTRODUCTION}

"The Pawtuxet River is the second largest source of fresh water flowing into Narragansett Bay. It provides as much as 25\% of the Bay's fresh water. The Pawtuxet River Basin is the largest river basin located solely within the state of Rhode Island (Figure 1.1). The Pawtuxet River begins as two branches (north and south) which meet at Riverpoint in west Warwick. From Riverpoint, the main stem of the Pawtuxet flows 12 miles downstream to Pawtuxet Cove in upper Narragansett Bay. The Pawtuxet River basin is located entirely in Rhode Island." (Cromwell, 1990)

The north branch of the Pawtuxet River is a 6.2 mile segment that has its origin at the Scituate Reservoir and ends at the confluence. The south branch consists of an 8.2 mile segment that begins at Johnson's Pond or the Flat River Reservoir and winds through Coventry to the confluence in west Warwick.

The study area of this report consists of the portion of the south branch that extends from the South Main street bridge to the dam located at Laurel Avenue (Figure 1.2). The study area also includes two of the 56 sub-drainage basins or reaches of the Pawtuxet River Basin as determined by the Department of Environmental Management.

The study area is located in Reach 40 and a portion of 
Rhode Island

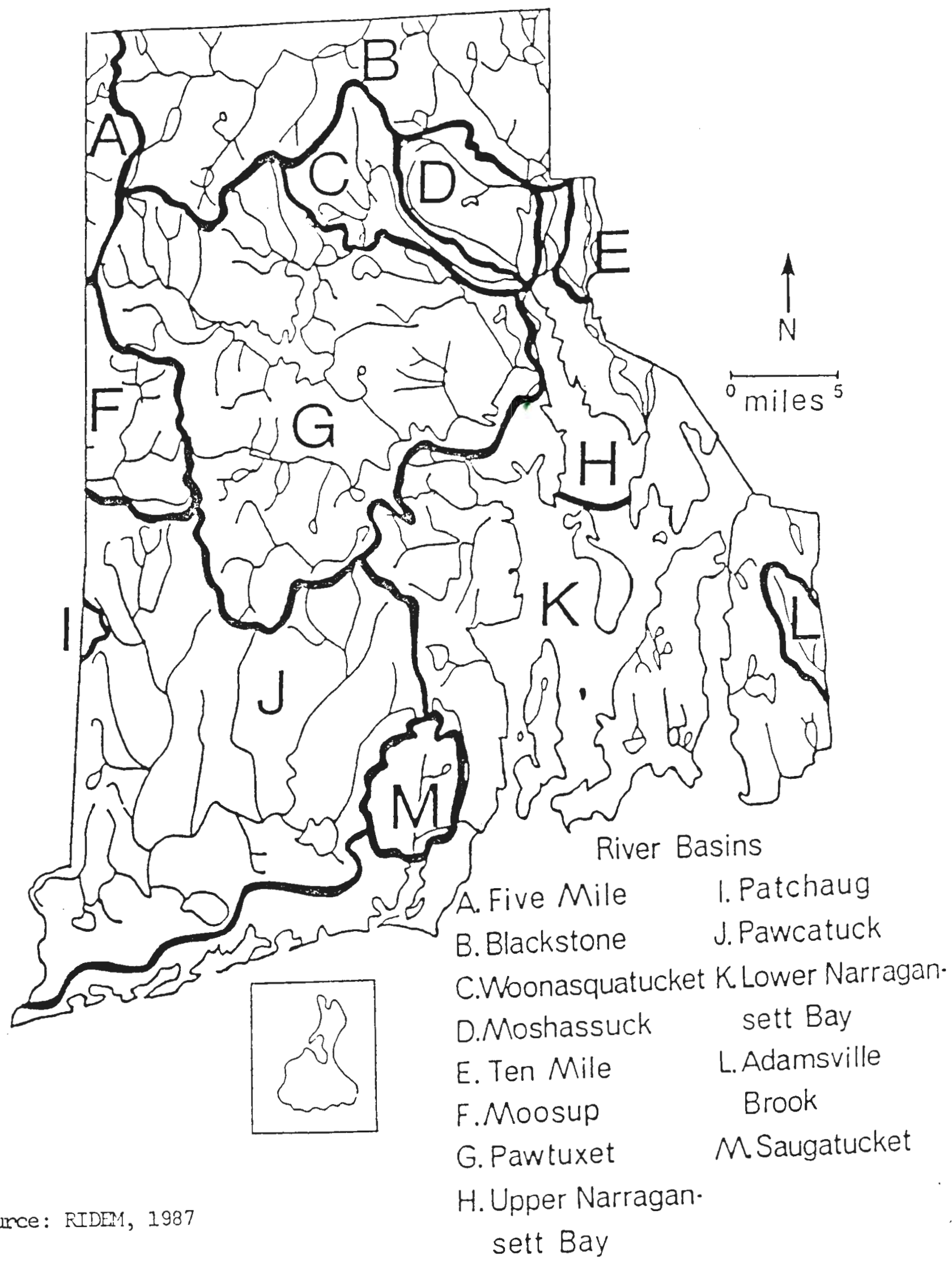


Reach 39. Reach 40 extends from South Main Street to Lake Tiogue. The portion of Reach 39 that the study area is in extends from Lake Tiogue to Laurel Avenue.(Refer to Figure 1.4)

\section{HISTORY}

"The Pawtuxet basin's (Figure 1.1) recorded history began in colonial America in 1642, when warwick was founded by Samuel Gorton. The town was named after Robert, Earl of Warwick in England. The Pawtuxet Indians who lived on the shore gave the river its name. In the Native American language, Pawtuxet means "place of little falls." During colonial times, many small communities dotted the river's edge near water-powered grist and sawmills. As demand increased for domestic goods, the basin's population grew.

The Pawtuxet River originally attracted industry because of its water power. Dams captured this energy and converted it to mechanical power for industry. In the combined length of the north and south branches (13.5 miles) 28 dams were built for industrial power. The first textile mill on the Pawtuxet was located in Centerville (West Warwick). Converted by resident Job Green from a gristmill, the textile mill produced cotton fiber. Between 1806 and 1809, 10 more textile 


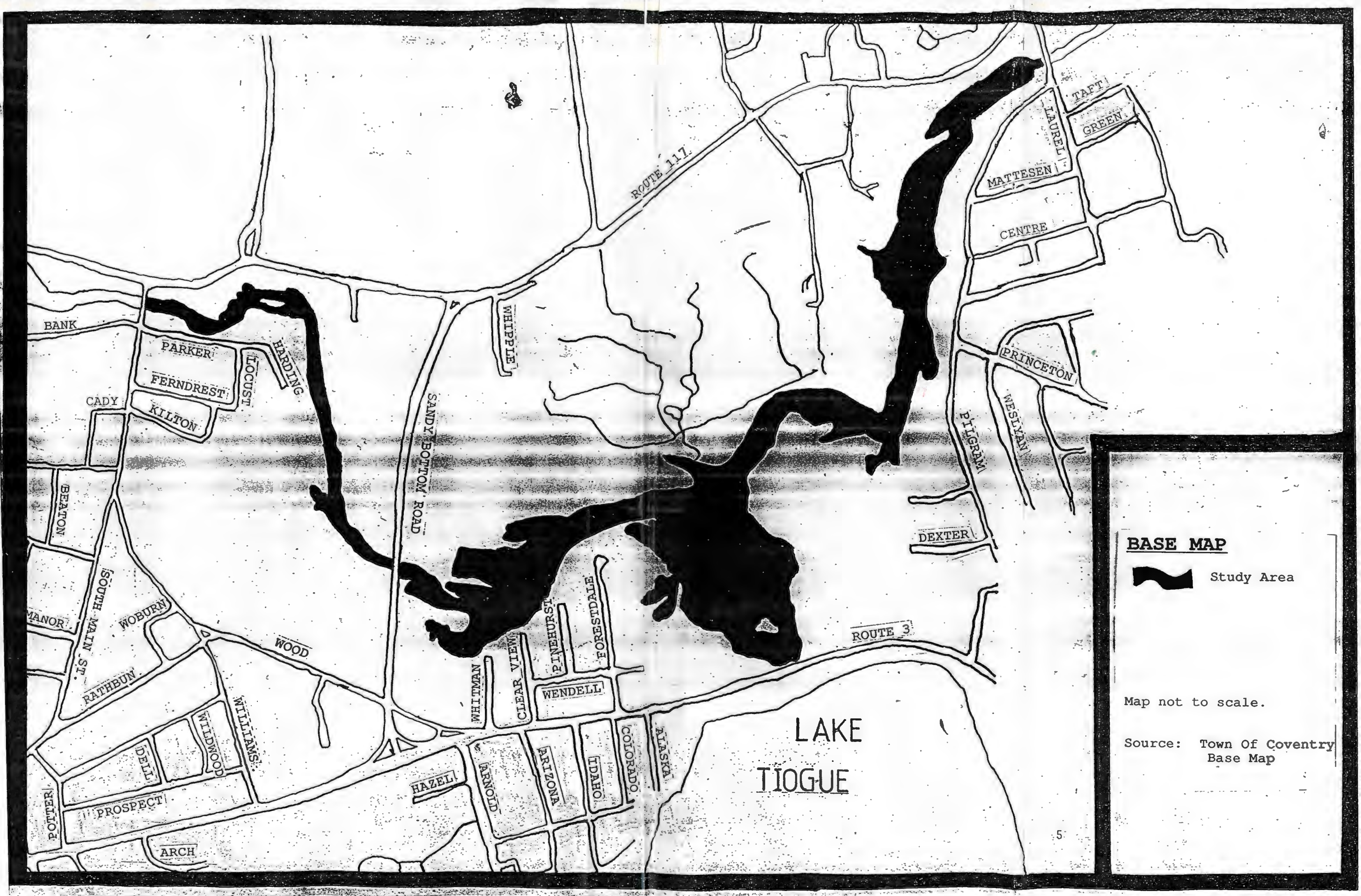


mills were built. The Lippit Mill, built between 1809 and 1810, still stands. Through 1920, the textile industry prospered. The popular "Fruit of the Loom" trademark was first coined by Pawtuxet River basin mill owners.

The Pawtuxet had another valuable function for industry: waste disposal. Dyes containing mercury, chromium and other toxic metals were rinsed out of cloth at the mills. The mill villages also used the river for household waste disposal. At the same time, Providence was using the Pawtuxet as its drinking water source. By fall 1891, the Pawtuxet was so polluted that Providence hired a special investigator to trace sources of pollution to the Pawtuxet. In May 1892, the General assembly appointed a special commission to study the Pawtuxet's pollution. Just 19 years later, unable to solve the Pawtuxet's problems, Providence decided to build the Scituate Reservoir by damming the upper portion of the Pawtuxet's north branch.

After the sharp decline in the textile industry in the 1920's, other industries came to fill the economic gap. Bradford Soap Works and other manufacturing firms helped revive the economy of the Pawtuxet River basin. As the population grew, human waste increasingly threatened the Pawtuxet's health. Finally, by the 1970's, the Pawtuxet became known as Rhode Island's dirtiest river."(Cromwell, 1990) 


\section{TOPOGRAPHY}

The topography of the study area generally is very characteristic of river basin topography. The river portion of the study area is extremely flat at about 180 feet above sea level. This portion measures approximately 9000 feet in length and drops from 190 to 170 feet above sea level. Thus the gradient for this portion of the river is $0.22 \%$. The gradient indicates that this portion of the river has a slow flow and a low flushing rate and allows pollutants that enter the river to be retained.

There are only two areas in the study area that have slopes greater than 15\%. These areas are located in the Saw Mill Hill area just to the south of the Village of Anthony, as shown in Figure 1.3.

\section{SURFACE WATER RESOURCES}

There are several surface water resources throughout the study area. Figure 1.4 depicts the study area, as well as the three reaches that are discussed in the study. Numerous wetlands, marshes, swamps and streams are located in each reach. Lake Tiogue is the largest body of water in the study area. it is connected to the pawtuxet through a culvert that passes under Tiogue Avenue (Route 3). Mishnock river and Mishnock Swamp are located to the south east of the study area. 




TOPOGRAPHY

-150 Topographic Iines At 50' Intervals

study Area

Fripli: Slopes Greater Than 158

Source: usGS Crompton, RI Quadrangle, 1975

Figure 1.3 


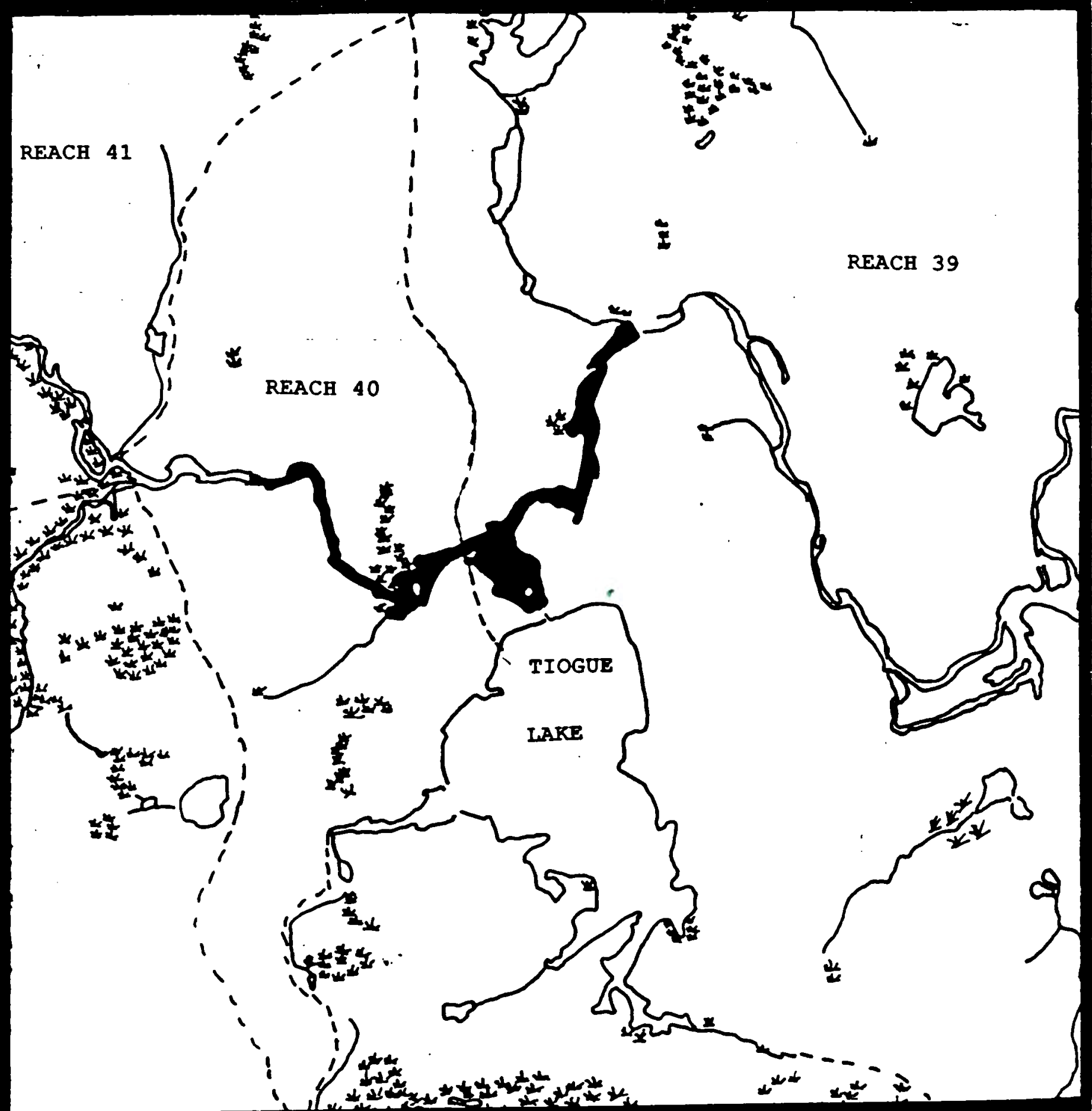

SURFACE WATER RESOURCES
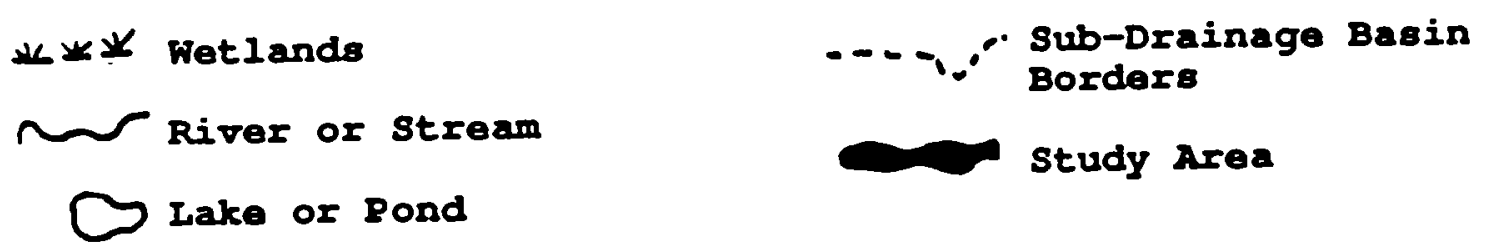

Source: USGS Crompton, RI Quadrangle, 1975

Figure 1.4 


\section{GROUNDWATER RESOURCES}

Groundwater deposits surround the study area as shown in Figure 1.5. The cross-hatched areas are those that are underlain by glaciofluvial deposits or glacial outwash. The outwash soils are porous and allow water to readily flow through them. While in the till soil, the water recovers at a slower rate.

\section{VEGETATION}

As can be seen on the following vegetation map (Figure 1.6), the greatest area of land surrounding the study area has been classified as Urban and contains little natural vegetation. However, there are also numerous small vegetated areas usually associated with river flood plain areas.

\section{SYMBOLS FOR VEGETATION TYPES}

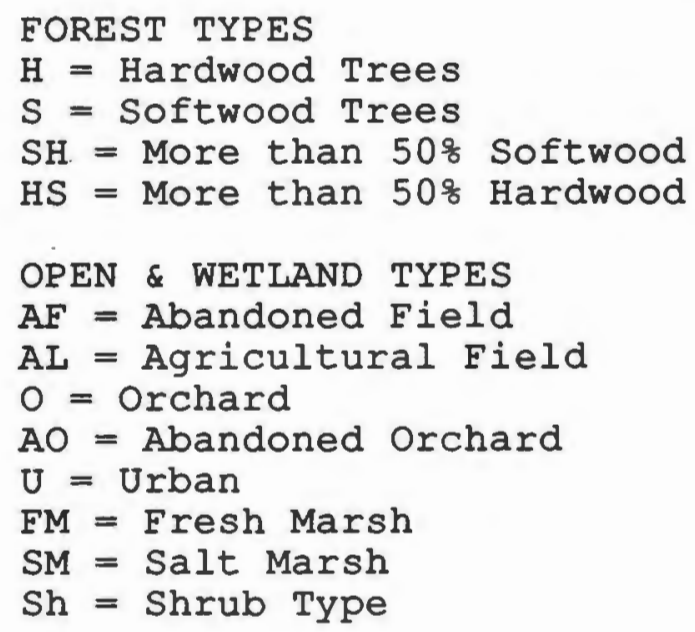





\section{HEIGHT AND DENSITY SYMBOLS}

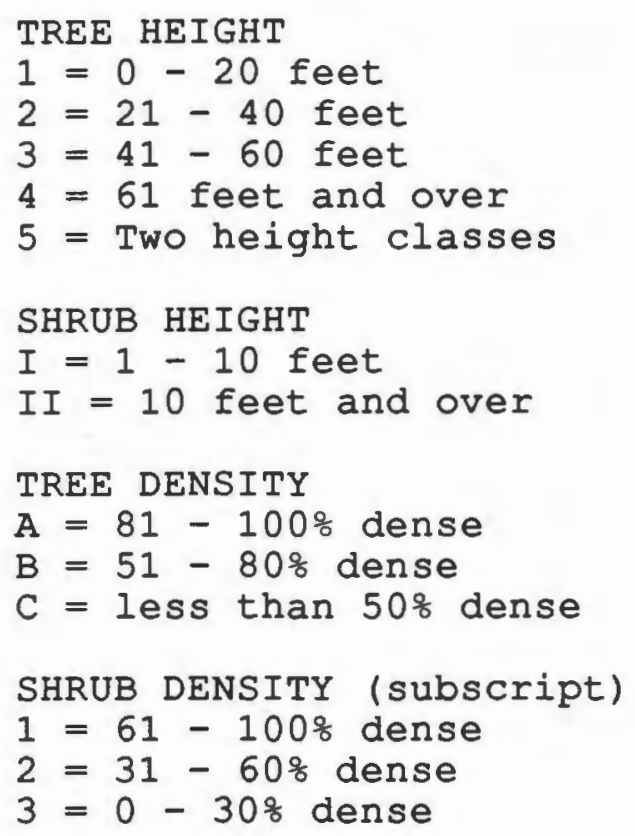

\section{SOIIS}

Soils play a key role in the pattern of urban development as it relates to nonpoint source pollution. The infiltration rate of soils determines the speed that water leaches and also the placement of individual sewage disposal systems (ISDS) .

\section{Soile}

$$
\begin{aligned}
& \text { Aa - Adrian } \\
& \text { CB - Canton-Urban } \\
& \text { ChC - Canton and Charlton } \\
& \text { Co - Charlisle } \\
& \text { HkC - Hinckley }
\end{aligned}
$$

Bydrologic Group

A/D

B

B

A/D

A
Septic Tank Absorption Fields

severe

slight

severe

severe

moderate 


$\begin{array}{lll}\text { MmA - Merrimac } & \text { A } & \text { slight } \\ \text { MmB - Merrimac } & \text { A } & \text { slight } \\ \text { MU - Merrimac-Urban } & \text { A } & \text { slight } \\ \text { NaB - Narragansett } & \text { B } & \text { slight } \\ \text { Nt - Ninigret } & \text { B } & \text { severe } \\ \text { Ru - Rumney } & \text { C } & \text { severe } \\ \text { Sb - Scarboro } & \text { D } & \text { severe } \\ \text { Ss - Sudbury } & \text { B } & \text { severe } \\ \text { UD - Udorthents-Urban } & \text { C } & \text { severe } \\ \text { Ur - Urban } & \text { C } & \text { severe } \\ \text { Wa - Walpole } & \text { C } & \text { severe } \\ \text { WgA - Windsor } & \text { A } & \text { A } \\ \text { WgB - Windsor } & \text { slight }\end{array}$

Source: Soil Survey of Rhode Island, USDA, 1977.

"Hydrologic Soil Group refers to soils grouped according to their runoff-producing characteristics. The chief consideration is the inherent capacity of soil bare of vegetation to permit infiltration. The slope and the kind of plant cover are not considered, but are separate factors in predicting runoff. Soils are assigned to four groups. In group $A$ are soils having a high infiltration rate when thoroughly wet and having a low runoff potential. They are mainly deep, well drained, and sandy or gravelly. In group D at the other extreme, are soils having a very slow infiltration rate and thus a high runoff potential. They have 
a claypan or clay layer at or near the surface, have a permanent high water table, or are shallow over nearly impervious bedrock or natural material. A soil is assigned to two hydrologic groups if part of the acreage is artificially drained and part is undrained." (USDA, 1977)

As can be seen on the following soils map (Figure 1.7) there are six types of soils that fall into the hydrologic soil type A. Five types of soil are classified as group B soils. Four as hydrologic group C. One as hydrologic group D. And two have been assigned to an, A/D mixture of hydrologic groups.

Of the 18 different types of soils located in the study area, 10 have severe constraints to ISDS. Figure 1.8 shows the soils with severe constraints for ISDS in the study area. The majority of these areas directly contact the river. These areas are shown in the Town of Coventry's Land Use Plan Development Constraints Map as being areas most suitable for development. The entire study area is considered to be in the most suitable category as shown in Figure 1.9 . It is apparent, that since no municipal sewer system exists in the town, that soils with severe constraint limitations were not considered to be a factor in determining the development constraints. 


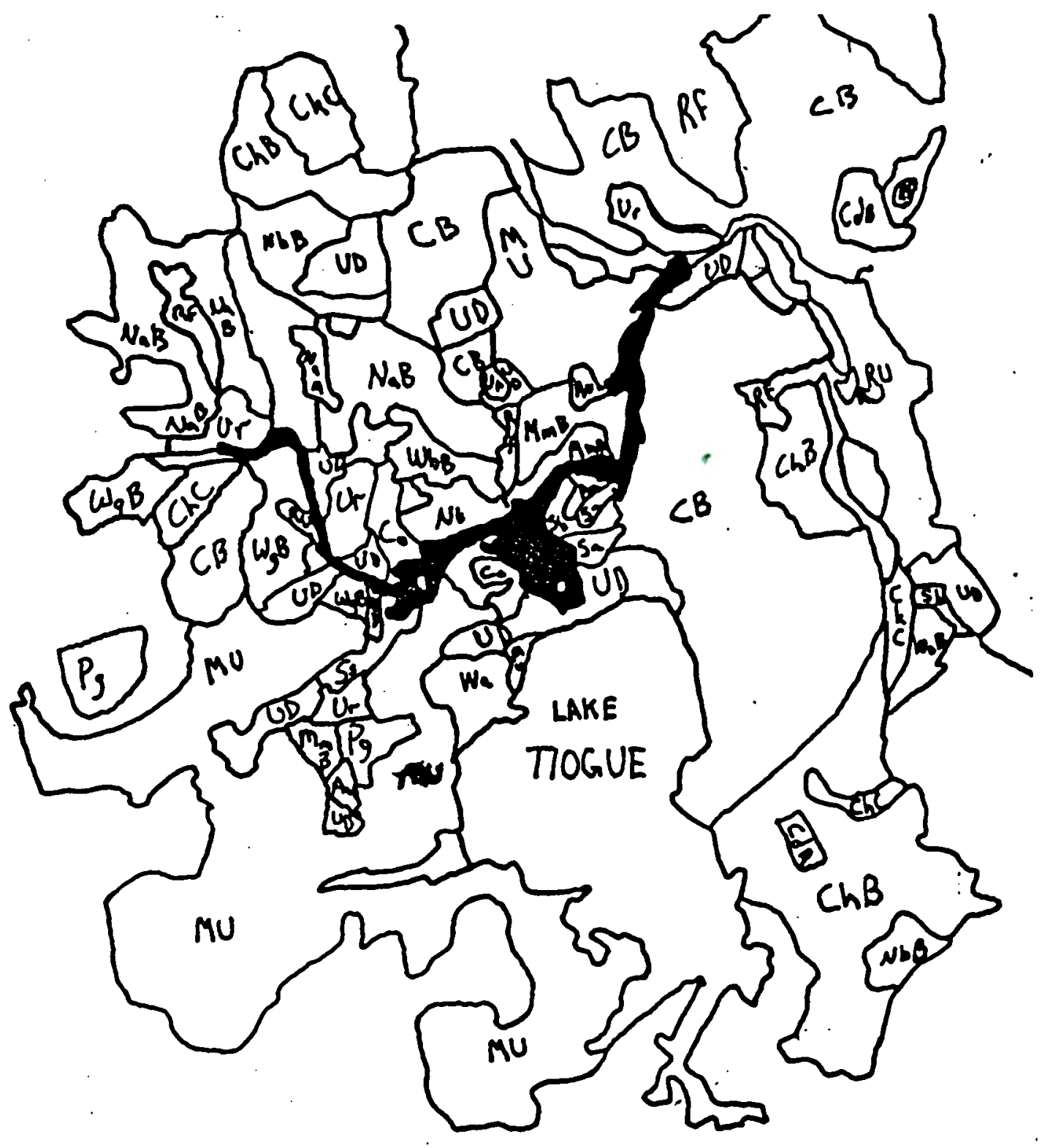

SOIIS

Corresponding list of Soil Types

is Included On Preceding Page.

study Area

Source: ISDA, Soil Survey of Rhode Island, 1977 


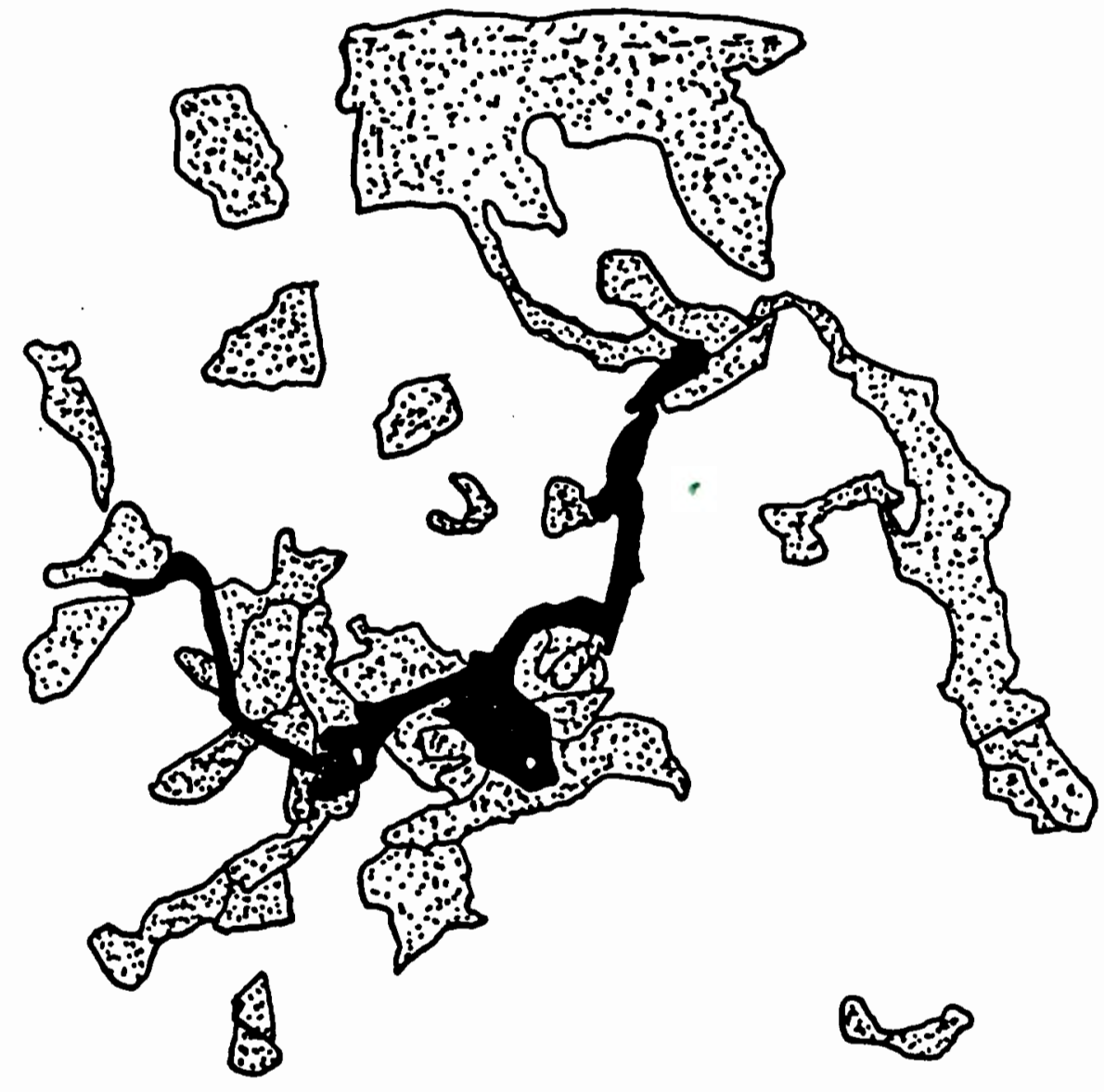

SOILS WITH SEVERE ISDS CONSTRAINTS IIMITATIONS

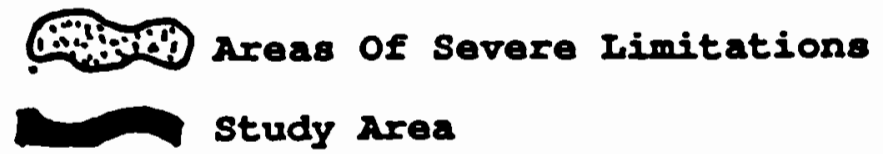

Source: USDA, Soil Survey Of Rhode Island, 1977

\author{
Figure 1.8
}




\section{INDIVIDUAL SEWAGE DISPOSAL SYSTEM (ISDS)}

"Septic Systems or individual sewage disposal systems (ISDS) are generally an inexpensive and acceptable means of sanitary and household waste water disposal. The biggest drawback to these systems is that they can fail to operate properly, creating a health concern and a possible water quality contamination source.

There are four factors that govern the proper operation and life expectancy of a septic system: 1) location; 2) design; 3)installation; and 4) maintenance. The first three are regulated by the Department of Environmental Management. Maintenance, since it is unregulated has been severely neglected by many homeowners."(Dept of Admin., Div. of Planning, 1987)

One problem that is plaguing cities and towns in the State of Rhode Island is that there is a lack of organization involving information and records pertaining to individual sewage disposal systems. The Town of Coventry is no exception. These records are gathered by the Department of Environmental Management and supplied to the local governments throughout the state. Town Building Inspectors are responsible for keeping the ISDS records for each town. The way that these records are kept makes using them extremely difficult and time consuming for the Building Inspector and any one else who may need to use them. The sparse septic system records do not include any records prior to 1968 . The 
reason for this, as reflected by one official from the Town of Coventry, is because ISDS was not an important issue before that time. But, in reality, this is because the Department of Environmental Management wasn't created until this time.

Out of the 89 lots in the study area that directly contact the river, there were only ISDS records for 15 of these lots. It is extremely important that the individual town governments have better access to these records.

Out of the 15 lots that there were records for, only 5 of the systems have been updated in the last decade. These lots are:

Plat 13 Lot 223 located between the river and Sandy Bottom Rd.

Plat 13 Lot 415 located between the river and Sandy Bottom Rd.

Plat 13 Lot 416 located between the river and Sandy Bottom Rd.

Plat 14 Lot 53

located between the river and Washington St.

Plat 23 Lot 166 located between the river and Rte. 117.

Plat 23 Lot 191 Located between the river and Rte. 117.

of these lots, Plat 13 Lots 415 and 416 share a common septic system, as well as, Plat 23 Lots 166 and 191 . The present land use for all four of these lots is commercial businesses.

From 1968 to 1976 , 304 maintenance, repairs and alterations to ISDS were approved. This, according to the 208 
Water Quality Plan for the State of Rhode Island, was the forth highest for a Rhode Island community during this period. "It has been well documented that ISDS requires maintenance to operate properly. Maintenance means the cleaning or pumping out of an ISDS on a regular basis, approximately every three years."(Dept. of Admin., Div of Planning, 1987)

For practical purposes, figure 1.10 has been included to show the diagram and layout of a typical domestic septic tank system. This diagram, taken from the Department of Administration Division of Planning's report entitled "Waste Water Management Districts... A Starting Point, Report \# 62" shows the path that domestic wastes travel through the process of the ISDS. "A septic system is comprised of the septic tank, distribution box, and leach field. Waste water enters the septic tank where solids settle to the bottom and excess liquid or effluent flows from the tank into a distribution box which evenly distributes the effluent into the leachfield. The waste water then percolates downward through the soil. Since most soil can be a good purifying medium, it can efficiently remove bacteria and viruses from household waste water if travel time through unsaturated soil is sufficient." (Dept. of Admin., Div. of Planning, 1987) The document in full is included in the Appendix A. 


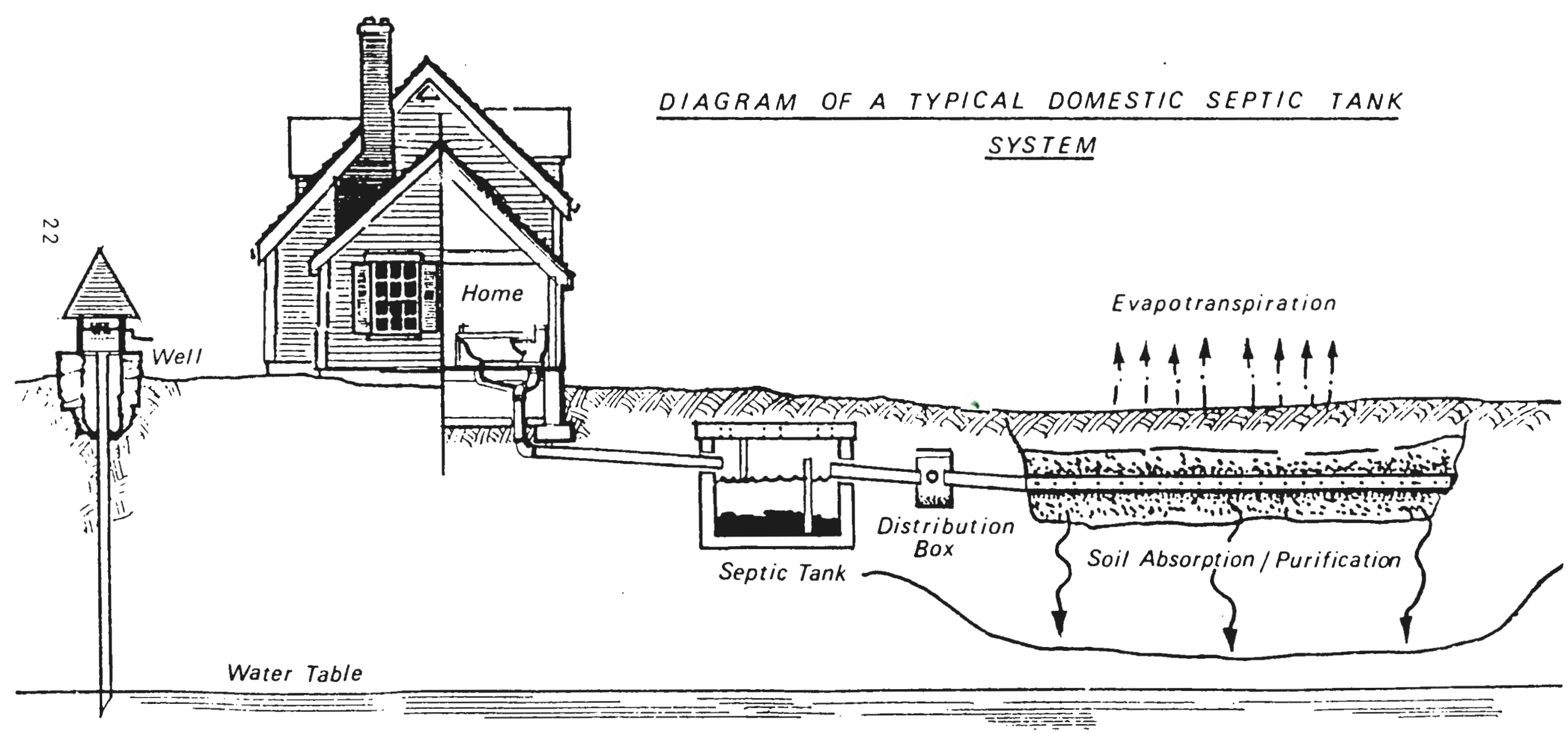

Source: The Rhole Island Lepartment of Atninistmetion, Mivision of Plannine, $1^{\text {nor }}$

Figure 1.10 


\section{PROBLEM AREAS}

The Facilities Plan Supplement compiled by the Coventry Water Quality Task Force in 1982 outlined 18 areas with septic system disposal problems. Of the 18 areas, 13 are in locations that have the potential possibility of affecting the portion of the river in the study area. "These areas have not been addressed in terms of correcting waste disposal since the preparation of The Facilities Plan Supplement in 1982."(BRW, 1990)

The 13 problem areas are listed below in no particular priority order:

-- Laurel Foster Nursing Home: Laurel Avenue and Center street.

-- Washington Street: Anthony South Side.

-- Village of Anthony: Edward, Knight, Hazard, Boston and Anthony Streets and surrounding areas.

-- Contentment street (elderly housing area).

-- Mister $V^{\prime} s$ on Tiogue Avenue.

-- The area located between Route 3, Arnold Road and Lake Tiogue, including Arizona street.

-- The area on the west side of Arnold Road north of little Tiogue.

-- The area near wood Street, South Main Street and Rathburn Street.

-- Garland Industries on South Main Street at Route 117.

-- Hopkins Hill Road near Little Huron.

-- East of Arnold Road south of causeway behind Tiogue Fire Station, adjacent to the Cardi property. 
-- Arnold Road and Holmes Road area.

-- Mohawk Street along east side of Tiogue Lake.

Source: Facilities Plan Supplement, August 1982.

All of these problem areas are located in one of the two sub-drainage basins that make up the up the study area. Any pollutants that escape the ISDS in these areas have the potential to reach the Pawtuxet River.

\section{SEWER POSSIBILITIES}

The Town of Coventry, at present, does not have a public sewer system. As can be seen by figure 1.11 from the 208 water Quality Plan for the State of Rhode Island, there is a tremendous need for a public sewer system. The major reason that sewers have not been added to the Town's infrastructure is due to the great cost of the project.

\section{IMPERVIOUS SURFACES}

There is a great deal of impervious surface area in the study area. In Reach $40,236.25$ of the 525 acres are estimated to be impervious surfaces. That is $45 \%$ of the total area of the reach. For the purpose of this study, it has been determined that a portion of the study area that is in Reach 39 occupies approximately $22.5 \%$ of the 3,914 total acres. The estimated size of the study area portion is 880.7 acres. Of 


\title{
MUNICIPAL SEWERAGE NEEDS
}

\author{
1 Existing Sewer Service \\ Industrial Zoned Sites
}

PROBABILITY OF NEED FOR SEWERS
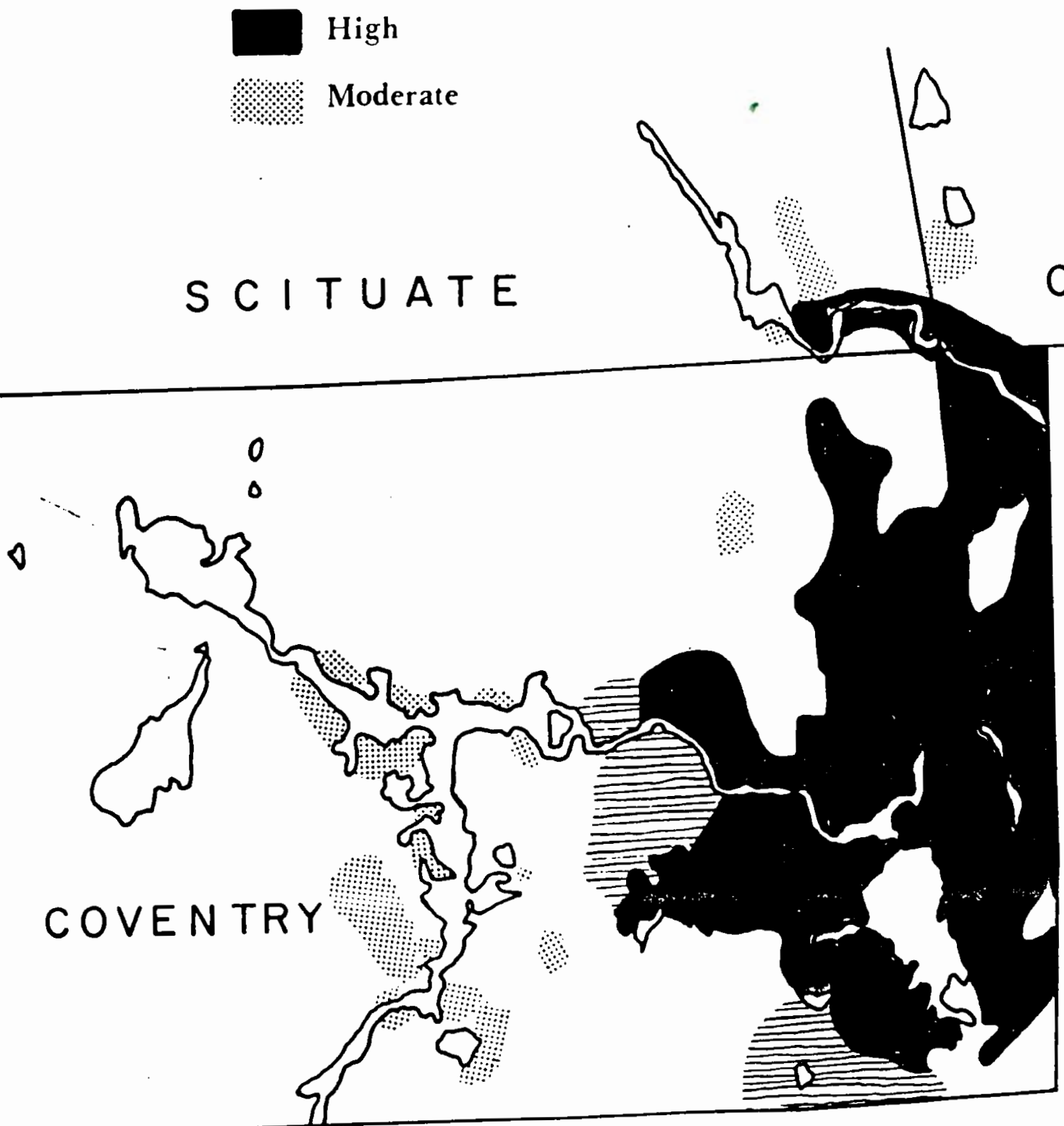

CRANSTON

Source: Fhode Island Department of Staterride Planning, 1979 
this 880.7 acres, 317 acres or $36 \%$ are estimated to be impervious surfaces. This can be seen in Figure 1.12.

Total

Area

Reach 39

Reach 40
880.7 acres

525 acres
Impervious

Surface Area

317 acres

236.25 acres
Percent Impervious $36 \%$ $45 \%$

These impervious surface estimates are based on 1985 zoned land use for the Town of Coventry. All of the land use classifications were taken into account in the impervious surface estimations. These estimations represent almost 50\% of the area surrounding the study area is impervious. This amount of impervious surface is capable of generating a large amount of stormwater runoff.

\section{STORMWATER RUNOFE}

Another major problem that has become an issue of concern in the study area is stormwater runoff. Figure 1.13 has been included to diagram the stormwater runoff cycle. Within the last couple of decades, there has been information that links stormwater runoff as a source of pollution that is depleting waterways of the essential oxygen demand as well as adding bacteria and other substances, some of which may be toxic. "Detectable levels of lead, zinc, iron, copper, chromium, cadmium, phosphorus, nitrates, coliform bacteria, sodium, 


\section{ESTIMATED PERCENT IMPERVIOUS LAND IN THE STUDY AREA}

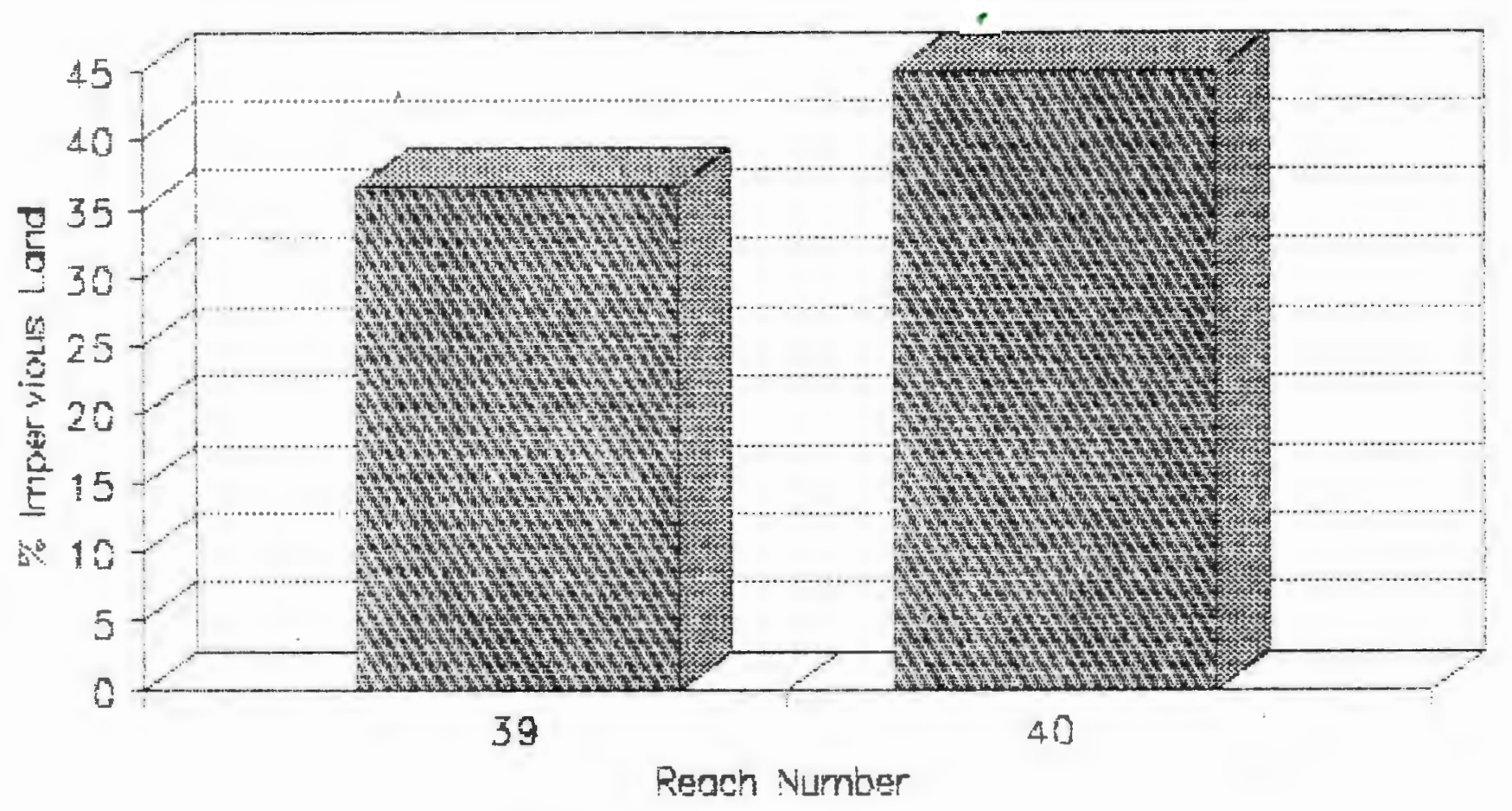

\% impervious Land

Soumce: 1985 land Use, Coventry,R.I.

Figure 1.12 


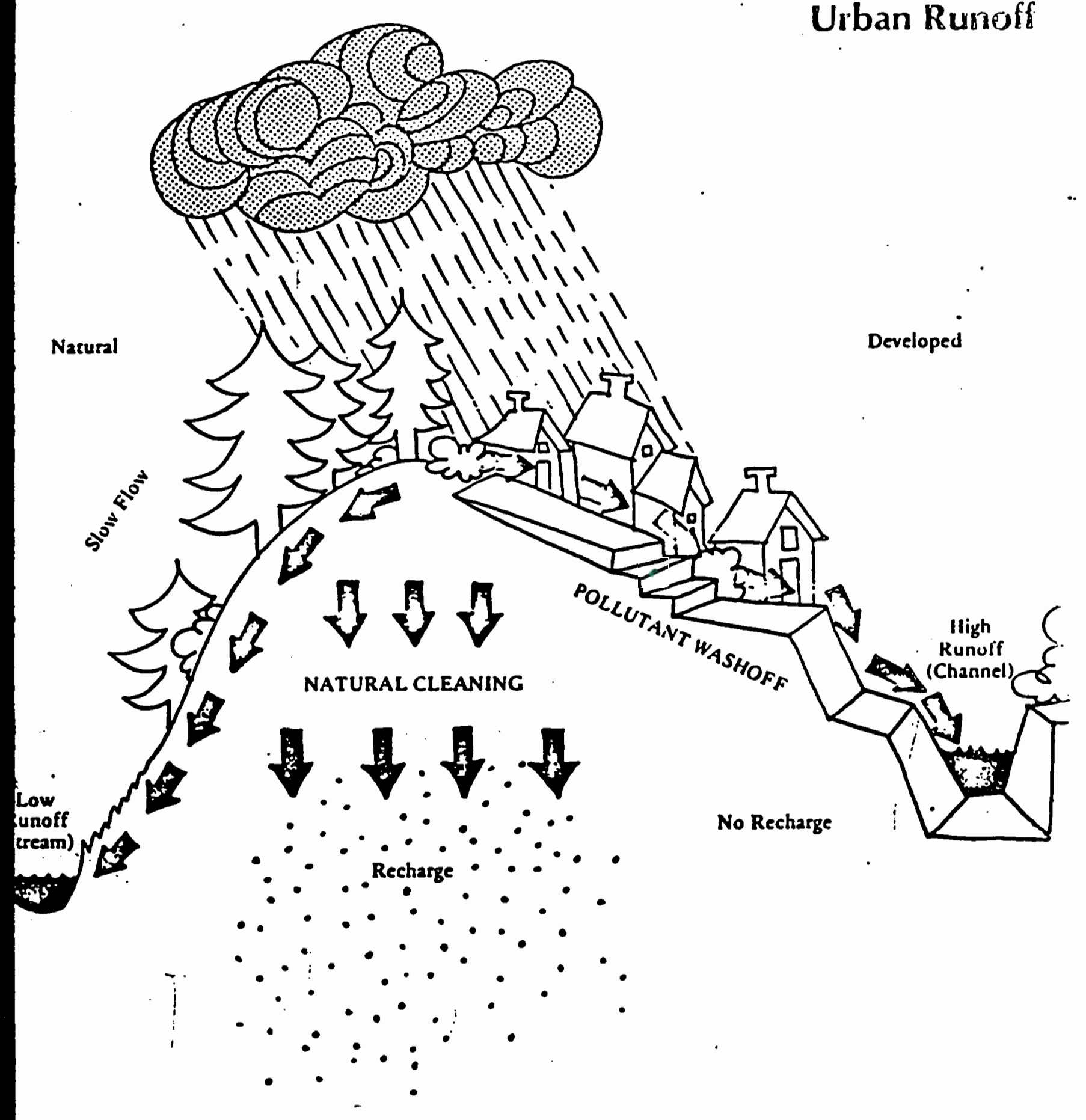

Source: Urban Land Institute, 1978

Figure 1.13 
chloride, and hydrocarbons have been found in stormwater runoff from urban areas." (RIDEM, 1988) Stormwater runoff is produced from rainfall, that by itself is an important and integral component of the natural hydrologic cycle. It becomes a source of pollution in urban areas, where it picks up many of the liquids and solids present on impervious surfaces and transports them to rivers and streams. The overall outcome of this is the degradation in the quality of the water.

"The immensity and complexity of urban runoff as a source of water pollution is understandable considering everything we see lying on the streets, curbs, gutters, sidewalks, or parking lots. Candy wrappers, empty cigarette packs, and other non-biodegradable litter; grass leaves, and other vegetative debris, pools of oil, iridescent slicks of gasoline, and other fluids from automobiles; wastes from pets; and salt and sand used to de-ice a winter road. All of these are carried by forces of travelling rain.

Things not quite as visible also go into urban runoff. Gaseous automobile emissions, the byproduct of the internal combustion engine, are cleansed from the air by falling rain. What polluted the air -- sulphur, nitrogen, and lead -- now also pollute the water. Lawn fertilizers, herbicides, and pesticides -- often ill-timed and excessively applied -- are washed away and can end up in a body of water that eventually may serve as a community's source of drinking water. Areas 
under construction, where the soil has been exposed, can be eroded by the force of rain, carrying valuable topsoil and nutrients to riverbeds. Over time these rivers will fill, causing downstream flooding and shoreline erosion." (O'Mara, 1978)

There are storm sewers located along Tiogue Avenue (Rte. 3), Sandy Bottom Road (Rte. 33), South Main Street and Route 117 that transport stormwater runoff to its disposal in the Pawtuxet River. This, combined with the surface flow of runoff from the streets without, storm sewers creates a significant waste load being brought to the river each time it rains. Figure 1.14 shows the approximate areas of the stormwater drainage systems. It also shows the direction of flow and the approximate points at which these systems drain into the river. There is neither a retention nor a detention system in place at the present time. There is nothing to filter the pollutants from the runoff before it enters the river.

Streets that affect the river through stormwater runoff:

- South Main St.

- Parker St.

- Harding St.

- Sandy Bottom Rd. (Rte. 33)

- Whitman St.

- Cedarview St.

- Pinehurst St. 


$$
n
$$


- Forestdale Ave.

- Tiogue Ave. (Rte. 3)

- Pilgrim Ave.

- Albro Ln.

- Donovan St.

- Dexter St.

- Mapledale St.

- Reddington St.

- Centre St.

- Laurel Ave.

- Princeton St.

- Wendll Ave.

- Clear View Dr.

- Whipple Ct.

\section{ROAD SALT}

Road salt or sodium chloride is applied to road surfaces, parking lots, driveways and sidewalks as a deicing agent during the winter months. The salt is combined with sand to provide added traction on the slippery surface. The residue from the salt or combination of salt and sand stays on the paved surface and in turn gets picked up in the stormwater runoff process.

"Salt as a deicing agent, would pose less of an 
environmental threat if it were applied properly. The excessive application of salt may cause environmental degradation. This can be due to a number of reasons: insufficient maintenance of equipment, antiquated equipment, insufficient operator training, inadequate supervision, poor record keeping or misinformation."(Dept of Admin., Div of Planning, 1990)

"The improper application and storage of road salt has been proven to contaminate surface and groundwater drinking supplies, damage roadside vegetation, impair fish and wildlife habitat, deteriorate highway structures, and corrode automobiles." (Dept. of Admin., Div. of Planning, 1990)

The policy of the Rhode Island Department of Transportation (RIDOT) is to apply 300 pounds per lane mile of roadway. RIDOT uses an approximate 3:1 ratio of sand:salt in their applications.

Although the Town of Coventry Public Works Department uses the same road salting standard mix ratio set by RIDOT, they don't apply the same amounts. They apply the salt/sand mixture as needed and where needed.

\section{SALT STORAGE}

The Town of Coventry stores their road salt behind the Town Hall in central Coventry. This storage location is not in the study area. It is however located in reach 41 near the 
beginning of the south branch of the Pawtuxet River and has the potential of leaching through the groundwater or over the surface to the river.

\section{DEBRIS INVENTORY}

The portion of the river that makes up the study area has been littered with debris throughout its length. Debris such as tires, car parts, rusty metal pieces, boards, metal cabinets, shopping carts, doors, mufflers, and vending machines. These are just a small númber of the articles that have been dumped into the river at various points. These articles dumped in and on the banks are continually adding toxins and other pollutants to the river. This debris also reduces the aesthetic character of the river and its surrounding area. Figure 1.15 shows the location of a majority of the visible debris, but there is also alot of nonvisible debris found in the river. Not long ago, a number of stolen vending machines were discovered in a deep portion of the river. (see Appendix B) 
C H A P T E R T W 


\section{CURRENT WATER QUALITY REVIEW}

The water quality of the portion of the south branch of the Pawtuxet River between the South Main St. bridge and the Laurel Ave. bridge is class $C$ due to the large number of industrial point sources combined with the increasing number of non-point sources in the area. Portions of this area are heavily developed and others are growing rapidly.

Section 6.2 of the Rhode Island Water Quality Standards classifies freshwater into 5 distinct classes.

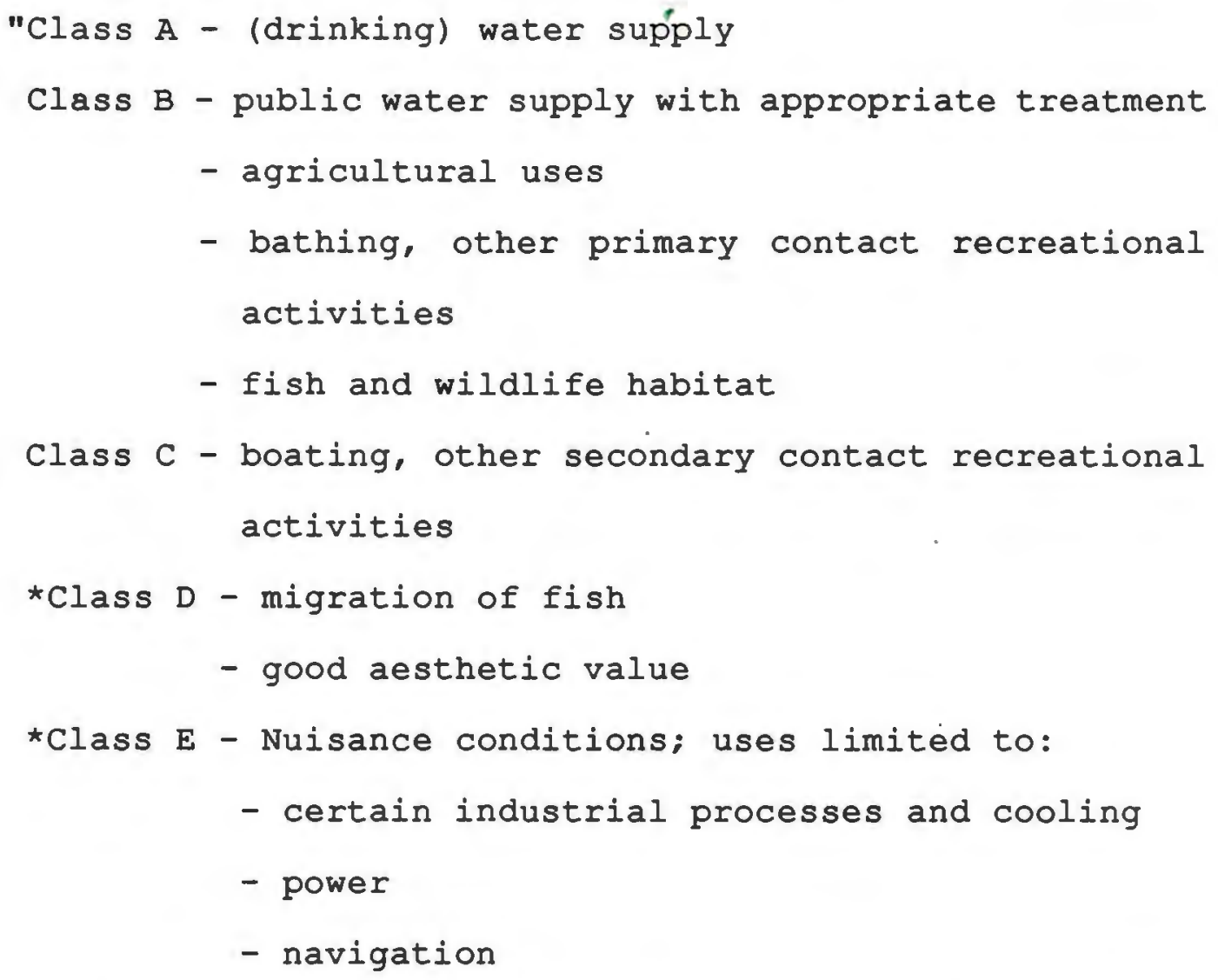

* Classes D and E shall be used to describe an existing condition only, and shall not be considered an acceptable goal for classification of any water." (RIDEM, 1988) 
"The groundwater aquifer associated with portions of the Big River and Flat River Reservoir also underlies most of this watershed. Kent County water Authority maintains four public wells near Mishnock Swamp and Tiogue Lake. This ground water source is high in manganese and the Authority is considering abandoning these wells when the Big River Reservoir is built.

In addition, one of the Tiogue wells has been contaminated with tetrachloroethylene and is not in use. Industrial wastes or individual sewage disposal systems (solvents are sometimes used to clean septic systems) are suspected sources."(Pawtuxet River Basin Non-Point Quality Standards Review and Management Plan, 1987)

Department of Environmental Management water quality sampling on Tiogue Pond has determined that the pond is maintaining Class B status as far as bacteria is concerned. There is a problem with eutrophication that is decreasing the appeal for swimming in the area. The pond is "shallow and nutrient rich, heavy residential development contributes runoff" (Ibid.) and the pond receives a very low level of clean inflow. "Full use of the pond is also limited by commercial development bordering the pond on Route 3. (Ibid.)

The 1986 RIDEM Stormwater Runoff Loadings And Impervious Area Calculations In The Pawtuxet River Basin Technical Report \#1 divides the study area into reaches or sub-drainage areas as determined by RIDEM's Division of Water Resources. Two reaches cover the study area. Reach 40 extends from the 
confluence of the Mishnock River and the south branch of the Pawtuxet to the junction between the south branch of the Pawtuxet and Tiogue Lake. Reach 39 extends from the Tiogue Lake junction to the confluence with the north branch. In order to determine the reach where the most non-point intrusion is estimated to occur, reach 41 was also added. Reach 41 extends from the Flat River Reservoir Dam to the confluence of the Mishnock River.

The pollutants that RIDEM included in their study are total suspended solids (TSS), biological oxygen demand (BOD), copper $(\mathrm{Cu})$, lead $(\mathrm{Pb})$, zinc $(\mathrm{Zn})$, and total phosphorus (TP). The amounts that this report comes up with are runoff estimates that are calculated by "identifying the different land uses, selecting a runoff coefficient and pollutant loading factor for each and determining the annual amount of rainfall."(RIDEM, 1986)

These runoff estimates are useful in determining any variations in the amount and types of runoff from one subdrainage area to another. They are also useful for making comparisons between sub-drainage basins and identifying potential problem areas throughout the sub-drainage basins.

These estimates "do not account for inputs from septic system failures, land fill leachate, or other concentrated non-point sources." (RIDEM, 1986) 
TSS

$\mathrm{mg} / \mathrm{I}$

97.32

$1 \mathrm{~b} /$ year

916,398

100.21

142,546

241.98

280.63

110.61

lb/acre/year

BOD

$\mathrm{mg} / \mathrm{l}$

6.45

$1 \mathrm{~b} /$ year

74,880

1b/acre/year

19.77

7.2

12,227

24.07

3.53

14,992

9.79

TP

$\mathrm{mg} / \mathrm{l}$

$1 \mathrm{~b} /$ year

$1 b / a c r e / y e a r$

.2

2,422

.64

.24

373

.73

.11

409

.27

$\mathrm{Cu}$

$\mathrm{mg} / \mathrm{I}$

.02

325

$1 \mathrm{~b} /$ acre/year $\quad .08$

.02

44

.02

.08

85

.05

$\mathrm{Pb}$

$\mathrm{mg} / \mathrm{l}$

.11

$1 \mathrm{~b} /$ year $\quad 1,596$

.1

185

.06

$1 b / a c r e / y e a r$

.42

.36

396

.24

$\mathrm{Zn}$

$\mathrm{mg} / 1 \quad .2$

$1 \mathrm{~b} /$ year $\quad 3,417$

$1 b / a c r e / y e a r \quad .90$

.16

304

.60

.2

1,259

.82

Source:"Stormwater Runoff Loadings and Impervious Area Calculations In The Pawtuxet River Basin", Technical Report \#1 RIDEM, 1986.

Maps depicting these runoff loading rates have been included in Appendix C.

From these estimates, it can be seen that the majority of these pollutants enter the river in sub-drainage basin 39 . Basin 39, as mentioned previously, extends from the river's juncture with Tiogue Lake to the confluence with the north 
branch. The boundary of this study includes only the small portion of this sub-drainage basin from the juncture with Tiogue lake to the Laurel Avenue dam.

There are also large amounts of these pollutants entering the river in sub-drainage basin 40 , which encompasses the majority of the study area. This basin has the lowest total suspended solids, biological oxygen demand, copper, lead and zinc estimates of the three sub-drainage basins. But all of these estimates are in excess of the acceptable amount.

The pollutant loading data shows that basin 40 has the highest annual load per acre when compared to the other two sub-drainage basins.

Sub-drainage basin 40 has the highest estimates of total suspended solids, biological oxygen demand, copper and total phosphorus. The estimates are also very high for lead and zinc. This sub-drainage basin is the smallest of the three basins discussed. The reason that these figures are so high is because there is a small amount of land area depositing such a large amount of pollutants through stormwater runoff into a short segment of the river. Therefore, the concentration of the pollutants is increased. This explains why the State of Rhode Island has classified the portion of the south branch beginning at the South Main St. bridge Class C waters. The section just prior, from the Flat River Reservoir to South Main St. (basin 41), has a water quality classification of Class $B$. 
For comparison purposes, the following figures are the Water Supply Source and Drinking water Standards for both the State of Rhode Island and the U.S. Environmental Protection Agency .

Rhode Island Standards

0.05
EPA

Regulations
Lead $(\mathrm{Pb})$

Zinc (Zn)

Copper (Cu)
5.0

1.0

From this, it can be seen that all three of the subdrainage basins are exceeding the Rhode Island standard for lead. Basin 39 is estimated to have more than two times the accepted amount of lead. Basin 40 is estimated to contain twice the accepted amount of lead. While basin 41 is estimated to exceed the standard by just $0.01 \mathrm{mg} / 1$.

All three of the sub-drainage basins are well below the Environmental Protection Agency's regulations for copper and zinc. 
$\begin{array}{llllllllllll}C & H & A & P & T & E & R & T & H & R & E\end{array}$ 


\section{MANAGEMENT STRATEGIES AND RECOMMENDATIONS}

The Rhode Island Department of Environmental Management's "Nonpoint Source Management Plan of 1988" uses Best Management Practices (BMP's) for nonpoint source pollution control. In this document, RIDEM developed a framework for nonpoint source pollution control. This framework breaks down their BMP's into ten different categories. These are:

1. Construction/Land Development

2. Urban Runoff

3. Highway Maintenance and Ruńoff

4. Individual Sewage Disposal systems (ISDS)

5. Agricultural Activities

6. Resource Extraction - Sand and Gravel

7. Recreational Activities - Marinas

8. Materials Handling and Storage

9. Underground Storage Tanks

10. Automobile Junk and Salvage Yards

It is extremely important that all of these factors and best management practices are reviewed and taken into account in present and future decisions made by the planning department in the town. The recommendations in this study will address only the topics brought up earlier: stormwater runoff, individual sewage disposal systems, road salt, impervious surfaces and debris. 


\section{STORMWATER MANAGEMENT}

At present, the Town of coventry is attempting to implement Wastewater Management Districts in the town. These districts will follow RIDEM's recommendations and guidelines in the Scituate Reservoir Watershed Management Plan. With the use of these management districts, the town will be able to "develop means to mitigate existing water quality contamination sources, and devise a management/regulatory structure necessary to oversee" (Div. of Planning, 1987) the flow of pollutants into the Pawtuxét River.

Best management practices or BMP's were developed in the late 1970's "for urbanizing areas that could remove urban pollutants and, in some cases protect downstream aquatic life. Most of these practices involve extra detention, retention or infiltration of urban stormwater to enhance pollutant removal and provide additional stormwater management. "(Schueler, 1987)

The "Vegetated Buffer Strip Designated Guidance Manual" recently developed for RIDEM and the Narragansett Bay Project by IEP, Inc. has set out "to provide guidelines for the determination of vegetative buffer strip widths for pollutant attenuation on a case-by-case (site-specific) basis. The purposed buffer designation (or sizing) method is aimed at mitigating stormwater quality impacts from urban and suburban developments." (Palstrom, 1991)

other vegetative best management practices include: 
grass swales, urban forestry, basin landscaping and shallow marsh creation. All of these methods are effective, simple ways to reduce particulate pollutant runoff in urban and suburban environments.

Figure 3.1 diagrams the process of the buffer designation model. This flow chart shows the steps that the reviewing person or committee would follow.

The special conditions evaluation (Figure 3.2) allows the reviewer to determine the suitable buffer strip width. The buffer designations range in sizes according to the surrounding land uses and physical features.

This plan to create buffer strips along rivers and wetlands to remove total suspended solids from stormwater runoff could be one effective method in the study area.

Another BMP would be to create extended detention ponds for the stormwater runoff. "Extending the detention time of dry or wet ponds is an effective, low cost means of removing particulate pollutants and controlling increases in downstream bank erosion." (Schueler, 1987)

Retention ponds or basins are another extremely effective BMP at a moderate cost to the developer. "If properly sized and maintained, wet ponds can achieve a high removal rate of sediment, BOD, organic nutrients and trace metals. Biological processes within the pond also remove soluble nutrients (nitrate and ortho-phosphorus) that contribute to nutrient enrichment (eutrophication). (Schueler, 1987) 
FIGURE 1

\section{BUFFER DESIGNATION MODEL OVERVIEW}

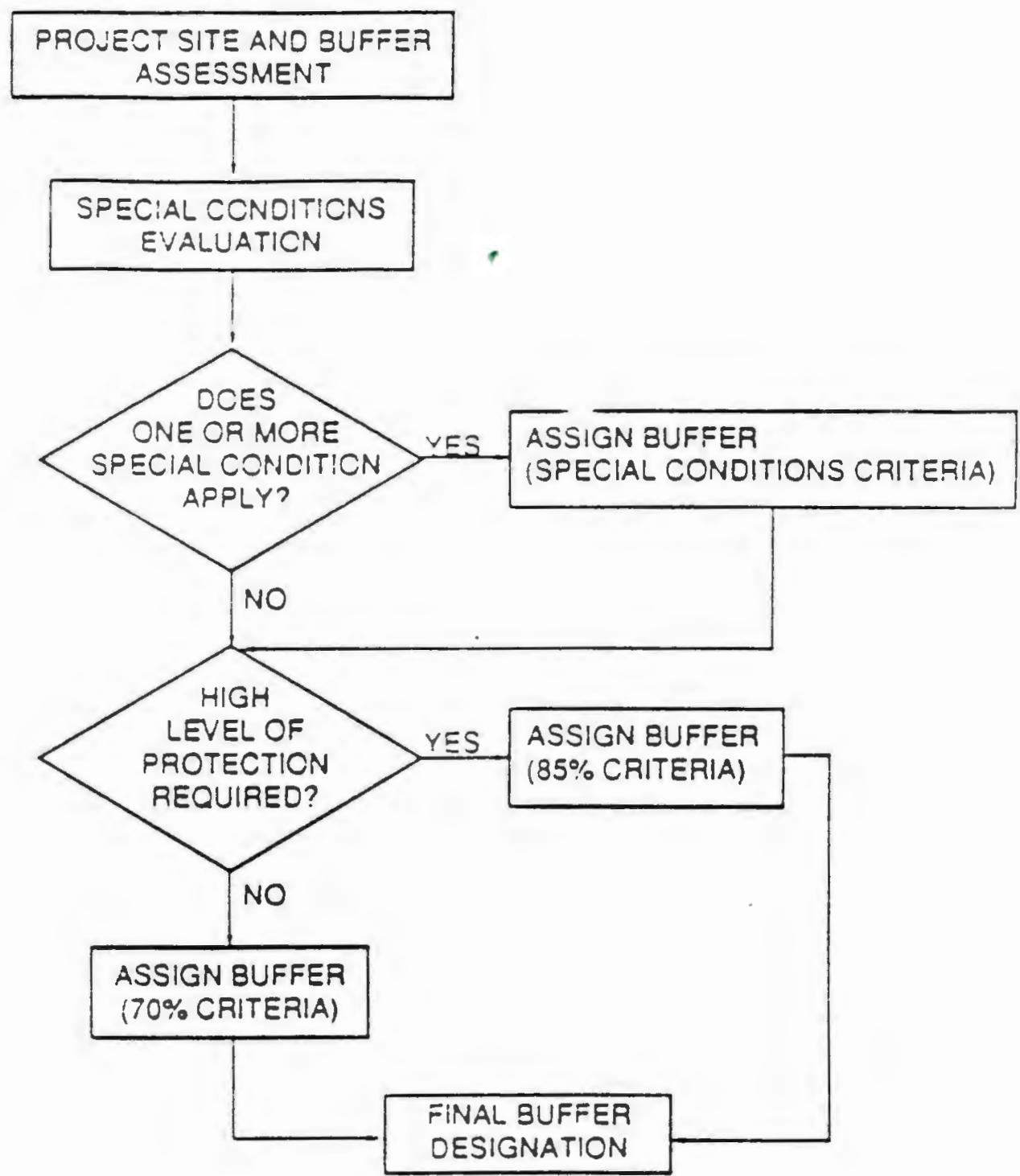


FIGURE 2

\begin{tabular}{l}
\hline SPECIAL \\
CONDITIONS \\
EVALUATION \\
\hline
\end{tabular}

IS OEVELOFMENT A COMMERCIAL

A OR INOUSTRIAL FACILITY THAT WILL HAVE HAZARDOUS MATERIALS ON SITE?

VES

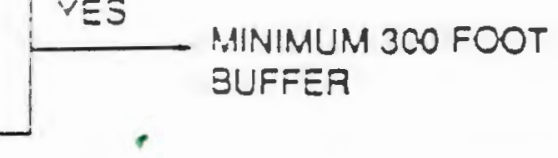

B IS DEVELCPMAENT INA

RESIDENTIAL INJFILL AREA?

i

IS THE POTENTIAL SUFFER

C AREA $>15 \%$ IN SLOPE OR WITH $<80 \%$ VEGETATICN COVER?

\section{1}

DOES THE WETLAND PROVIDE

D PRESENT OR DOCUMENTED

HABITAT FOR THREATENED OR ENOANGERED SPECIES
BUFFER CONSISTENT WITH EXISTING BUFFERS: BUT NOT LESS THAN 25 FOOT MINIMUM

BUFFER NOT SUITABLE FCR WATEA OUALITY PROTECTION IES IOTHER MITIGATIVE MEASURES REQUIRED): ASSIGN BUFFER IN ACCORDANCE WITH NOISE ATTENUATION ONLY.

YES SEE RHODE ISLAND NATURAL HERITAGE PROGRAM

IF NO SPECIAL CONOITIONS APPLY .

PROCEED TO BUFFER DESIGNATICN

PROCEDURE. 
Infiltration trenches are another BMP that removes both soluble and particulate pollutants from stormwater. Trenches are best suited for on-site control. They may only be ideal for selected areas because they "are only feasible when soils are permeable and the water table and bedrock are situated well below the bottom of the trench.

Infiltration basins are also an effective method of removing soluble and particulate matter from stormwater runoff. This type of basin is easily adaptive to different sites and different storm conditions.

"Porous pavement has a high capability to remove both soluble and fine particulate pollutants in urban runoff, and also provides groundwater recharge, low flow augmentation and streambank erosion control."(Schueler, 1987) This might be an effective way for the town and state to control the level of pollutants entering the study area. There are a number of roads in the surrounding area that are slated for repairs and resurfacing. The town along with RIDEM could possibly set up porous pavement districts along the river.

Figures 3.3 through 3.6 have been included to show the restrictions, benefits, pollutant removal and community amenities of each of the previously mentioned best management practices. 


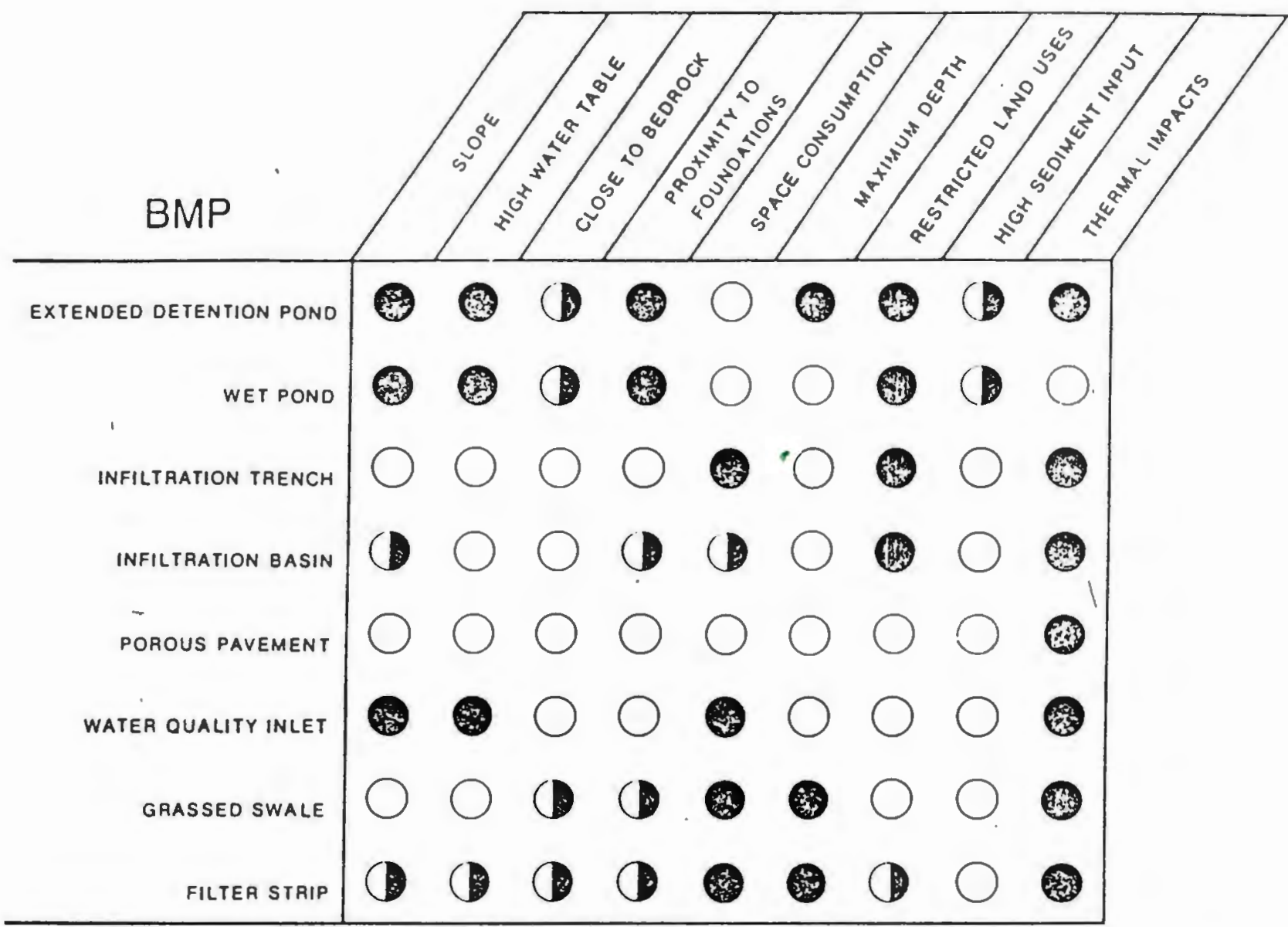

O may paeclude the use of a bmp

(1) can be ovefcome wi careful site design

Figure 3.3

(9) genefally not a aestaiction

Source: Schueler, Thomas; Controlling Urban Runoff: A Practical Manual For Planning And Designing Urban BMP's, 1987 


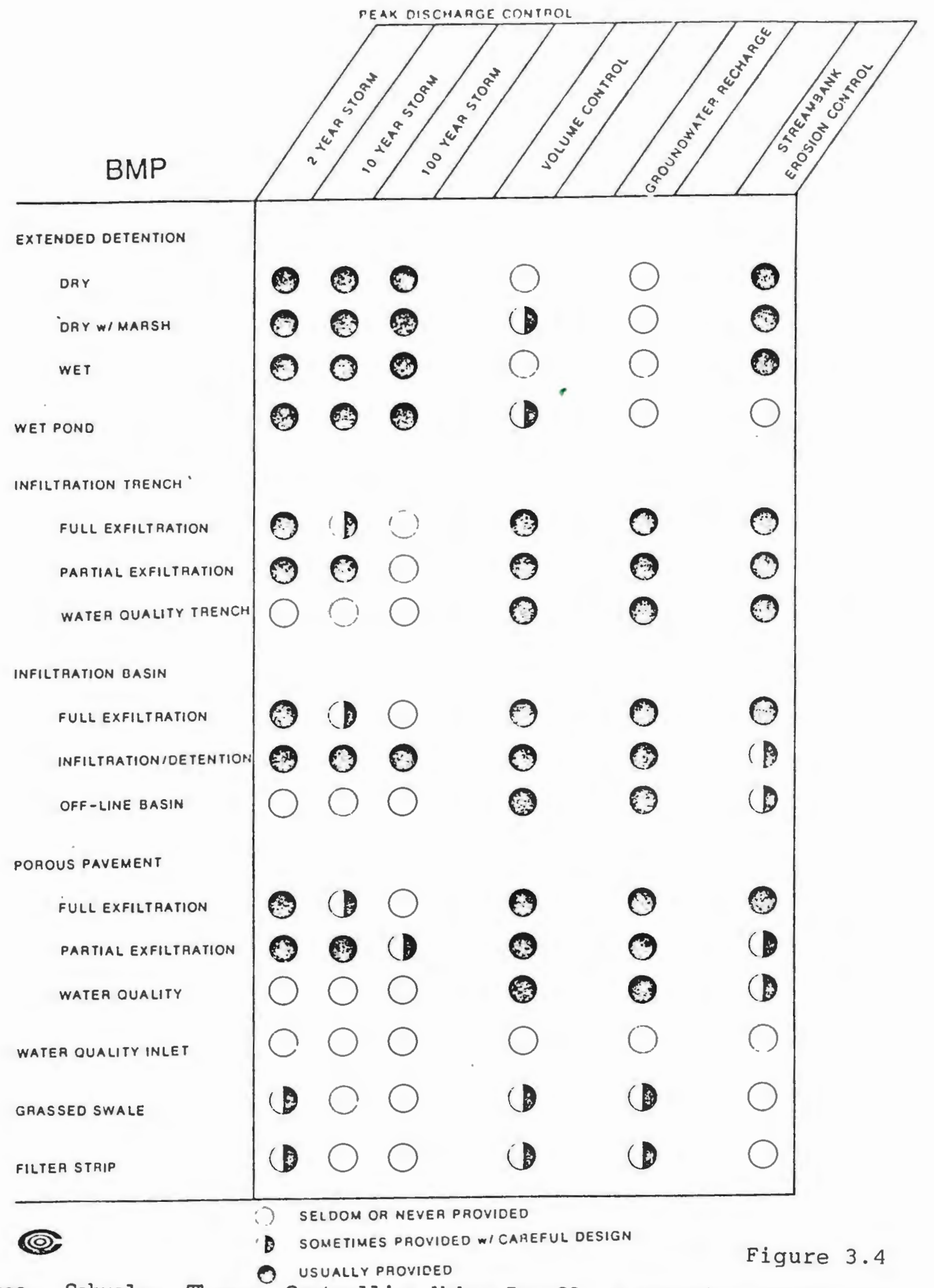

Source: Schueler, Thomas; Controlling Urban Runoff: A Practical Manual For 


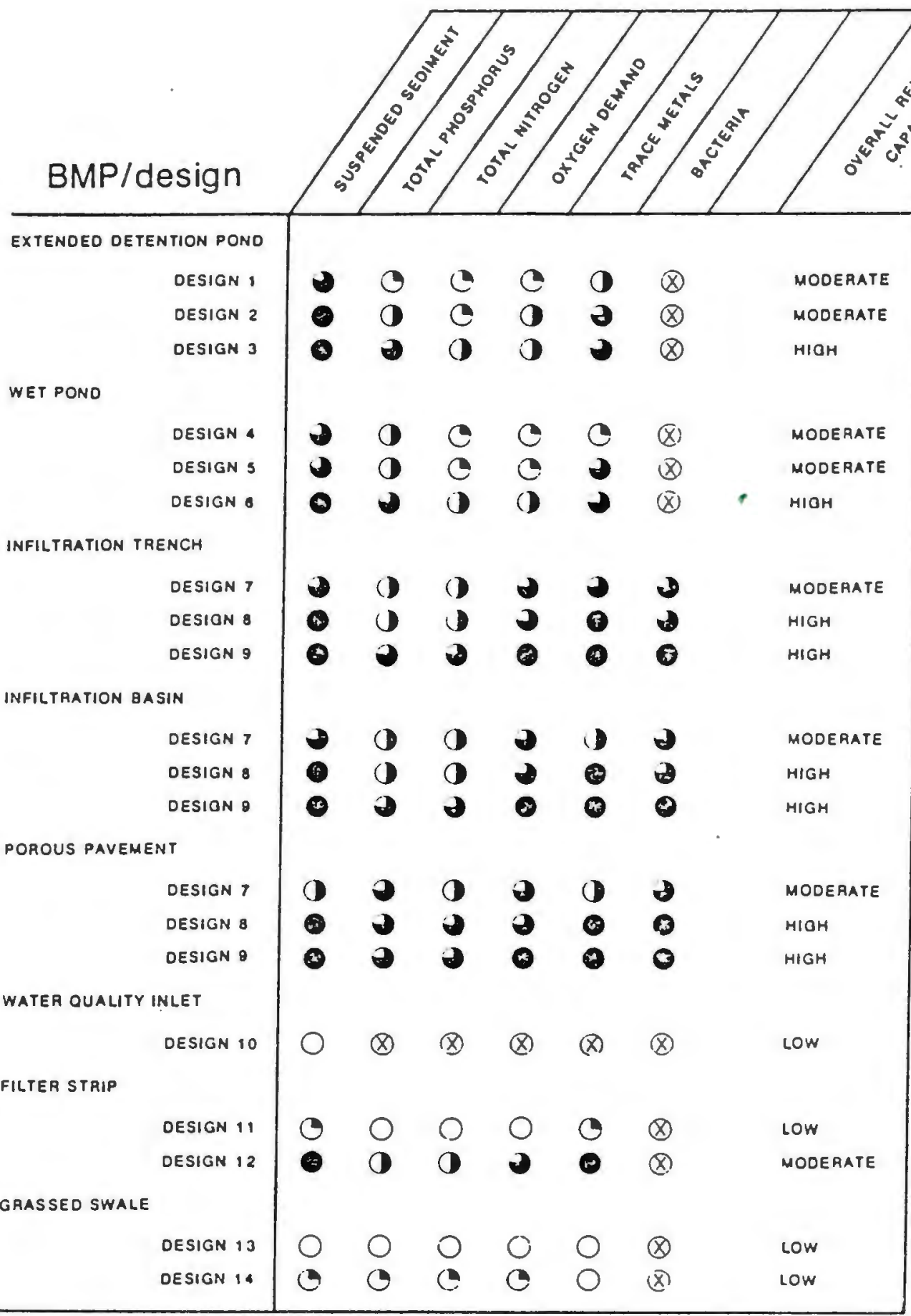

O TO 20 $\times$ AEMOVAL

(3) TO $20 \times$ REMOVAL

(1) 40 To $60 \%$ Removal

(-) 60 to go* removal

(80 to $100 \%$ Removal

(X) INSUFFICIENT KNOWLEDOE

Figure 53.5

Design 1: First-flush zunoff volume detaned for $0-12$ hours.

Design 2: Runoff volume produced by 1.0 inch, decained 24 hours.

Design 3: As in Design 2, but bith shallow marsh in bottom stage.

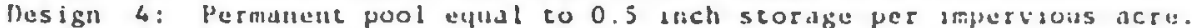

Design 5: Permanent pool equal to 2.5 (Yr); where lir=mean stcrm runoff.

Lasign 6: Permanent pool equal to $\dot{0} 0$ ( $(\mathrm{H})$; approx. Z weuks retention.

Design 7: Facilicy exflerates firse-flush; 0.5 inch cunof t, imper. acre.

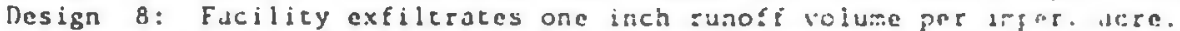

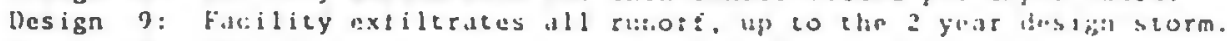

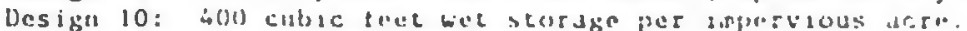

Design 11: 20 toot bide curf strip.

Design 12: 100 foot bide forested strip, with level spreader.

Design 13: High slope sidulus, with no cliecit ails.

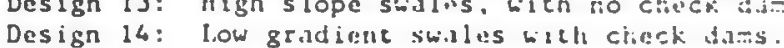

Source: Schueler, Thomas;

Controlling Urban Runoff:

A Practical Manual For

Planning And Designing 


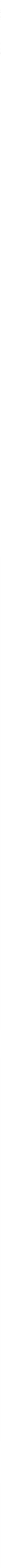

Soumce: Schueler, Thomas; Controlling Urban Runoff: A Prattical Manual For Planning And Designing Urban BAP's, 1987 


\section{INDIVIDUAL SEWAGE DISPOSAL SYSTEMS (ISDS)}

First and foremost, it is extremely important that the Department of Environmental Management create ISDS data bases that can be easily accessible to the towns. These data bases would also have to be updated regularly in order for town officials as well as RIDEM officials to make accurate and consistent decisions pertaining to ISDS problems and concerns. This data could also possibly be included in the Rhode Island Geographical Information system (RIGIS). Maps could be created depicting the locations of I'SDS. From these it could be easier for agencies, whether it be town planners or RIDEM officials to deal with ISDS applications. This ISDS information can also be overlayed with constraints maps to determine current and potential problem areas.

The Town should also review its new development constraints map taking into account poor soils for ISDS placement. At present, the map depicts a community that is partially or even fully sewered.

Another recommendation is that the Town of Coventry adopt and enforce Waste Water Management Districts as proposed by the Department of Administration's Division of Planning. "This plan recommended that municipalities assume an active role in preventing septic system failures by establishing maintenance programs."(Dept. of Admin., Div. of Planning, 1987)

Developing the sewer system infrastructure for the 
eastern portion of the town is imperative.

The Town of Coventry's Planning Department, headed by Charles Gricus, is working on utilizing RIDEM's Wastewater Management District Guidelines. They are also in the process of researching federal grants and that would allow the town to put sewers in place. Section 101 of the Federal Water Pollution Control Act states that "it is the national policy that Federal financial assistance be provided to construct publicly owned waste treatment works."(33 U.S.C. 1151)

If successful, the town might be able to hook up a portion of the system to West Warwick's system. If the majority of the town is to be sewered, the town may have to build its own sewer treatment plant. This would bring about a tremendous financial burden as well as extreme negative affects to the Pawtuxet River if not planned and designed properly. One excellent document to refer to is "Developing $A$ Small Community Sewage Facility Through A Municipal Authority", by The Pennsylvania State University, College of Agriculture. This document outlines strategic planning, design and cost estimates for the development of a facility. This document is included in Appendix D.

\section{ROAD SALT}

In order to assist in the reduction of sodium chloride that enters the river, the Town could attempt to adopt the road salt policy that is in effect in the scituate Reservoir 
watershed. It would only be necessary to implement this strategy along roads in which the runoff directly enters the river.

\section{IMPERVIOUS SURFACES}

In order to cut down on impervious surfaces the town can, in the zoning regulations, request that new developments in a determined area around the river use either porous pavement or gravel in their parking areas and driveways.

\section{DEBRIS}

The elimination of debris in and along the river can only be achieved if the general public is informed about the river. Education is the strongest advocate working for this cause. This step can begin in the school system for the children. Agencies such as the Pawtuxet River Authority and River Watchers can educate the adults in the community as to the impacts of debris within and surrounding the river. 
$\begin{array}{lllllllllll}C & H & A & P & T & E & R & F & O & U & R\end{array}$ 


\section{SUMMARY}

It is imperative that a combination of local, state and federal agencies as well as concerned public interest groups become involved to reclaim the water quality of the south branch of the Pawtuxet River.

This study attempts to bring together a set of water quality degrading nonpoint sources of pollution for an area of the river that has not yet been specifically studied. The majority of the previous studies concentrated on either the river as a whole or the area around the scituate Reservoir Watershed. The studies that looked at the south branch were predominantly concerned with the areas to the east that deal with the sewage treatment plants and the confluence with the main stem of the river.

All of the nonpoint pollution sources mentioned in this study are present in some capacity in the areas surrounding the river. Individual sewage disposal systems "can fail to operate properly, creating a health concern and a possible water quality contamination source." (Dept. of Admin., Div. of Planning, 1987) Stormwater runoff, road salt and debris are also known nonpoint contaminants. If all of these agencies work together to initiate some of the recommendations listed in the previous chapter, there will be a noticeable improvement in water quality over time in the upper southern branch. All facets of nonpoint pollution must be addressed in 
order for this to take place.

The recommendations that address these problems are common solutions that are readily used in other communities throughout the country. There are many examples available to determine the solution that fits the specific situation.

All of the previoulsy mentioned nonpoint source pollution problems that exist in the study area are important and need to be addressed, but there are two key areas that require more immediate attention. These are the areas of stormwater runoff and ISDS. The Town must work with the appropriate state and federal agencies to remedy these problems. If an adequate storm drainage system and a sewer system is installed throughout the study area, the untreated pollutant load into the river will be greatly reduced. It is up to the present generation to save the Pawtuxet for the future. 
$\begin{array}{llllllllll}R & E & E & E & E & N & E & S\end{array}$ 


\section{REFERENCES}

-- BRW Engineering, Comprehensive Community Plan of the Town of Coventry, Rhode Island. 1990.

-- Coventry, Town of, Zoning ordinance for the Town of Coventry. 1988.

-- Department of Environmental Management, Rhode Island, An Assessment of Nonpoint Sources of Pollution to Rhode Island's Waters, Final Report. August 1988.

-- $\frac{}{\text { Oct., 1988. }}$ Rhode Island Water Quality Standards,

-- Stormwater Runoff Loadings and Impervious Area Calculations In The Pawtuxet River Basin. Sept., 1986.

-- The State of the State's Waters - Rhode Island - A Report to Congress. April, 1990.

-- $\frac{}{\text { Plan. 1988. }}$. Rhode Island's Nonpoint Source Management

-- Pawtuxet River Basin: Nonpoint Water Quality Standards Review And Management Plan. 5-1-87.

-- Division of Planing, Rhode Island Department of Administration, Waste Water Management Districts... A starting Point, Report \#62. 1987.

- Scituate Reservoir Watershed Management Plan, Report \# 70, State Guide Plan Element 125. December 1990. -- Rhode Island State Enabling Acts

-- The Rhode Island Land Use Plan - A Summary.

-- Harmic, Jay L., Minimizing Urban Runoff During Development. Environmental Comment Dec., 1978.

-- Kupa, John and Whitman, William, Crompton, R.I. Quadrangle - Forest and Wetland Vegetation Types. 1972.

- McCarthy, Brian, Fate and Transportation of Heavy Metals in the Pawtuxet River. 1986. 
-- Metcalf and Eddy, Inc., Pawtuxet River, Rhode Island: Use Attainability Study. 1983.

- Michigan Department of Natural Resources, Michigan Guidebook For Surface Water Discharges, 1987.

- Natural Resources Defense Council, Poison Runoff: a guide to State And Local Control of Nonpoint Source Water Pollution. 1989.

-- Northeast Michigan Council of Governments \& Tip of The Mitt Watershed Council, Burt Lake Watershed Non-Point Source Management Plan. Sept. 30, 1987.

-- Novotny, Vladimir and Chesters, Gordon, Handbook of Nonpoint Pollution: Sources and Management, 1981.

-- O'Mara, Connie Weis, Environmental Comment, Urban Land Institute, December 1988.

-- Palmstrom, Nancy, IEP, Inc., Vegetative Buffer Strip Designation Method Guidence Manual, 1991.

-- Pawtuxet River District Commission, Pawtuxet River District Commission Final Report. Dec. 7, 1990.

-- Pennsylvania State University, College of Agriculture, Developing a Small Community Sewage Facility through a Municipal Authority. Date N/A.

-- Quinn, James, Hoffman, Eva, Latimer, James \& Carey, Constance, A Study of the Water Qaulity of the Pawtuxet River: Chemical Monitoring and Computer Modeling of Pollutants. June, 1985.

-- Rhode Island Sea Grant, Pollution Impacts From Recreational Boating: A Bibliography and Summary Review. 1990.

-- Rhode Island Statewide Planning Program, 208 Water Quality Management Plan For Rhode Island. March, 1979.

-- Schueler, Thomas, Controlling Urban Runff: A Practical Manual For Planning And Designing Urban BMP's, 1987.

-- United States Geological Survey, Crompton, R.I. Quadrangle. 1975.

-- Ground water Map for the South Branch of the Pawtuxet River Basin. 1955. 
-- Warren, Richard E., Drainage As A Municipal Utility, Environmental Comment, Dec., 1978.

- Water Pollution Control Federation, Clean water For Today: What is Wastewater Treatment, Date N/A.

-- Yousef, Yousef A., Hvitved-Jacobsen, Thorkild, Wanielista, Martin P. \& Tolbert, Robert D., Nutrient Transformation in Retention/Detentión Ponds Receiving Highway Runoff, August, 1986.

- 33 U.S.C. 1151 The Federal water Pollution Control Act, 1972. 
A P E N D I X 
$\begin{array}{llllllllll}A & P & P & E & N & D & I & X & A\end{array}$ 
WASTE WATER MANAGEMENT DISTRICTS...

A Starting Point

December, 1987

THE STATE OF RHODE ISLAND AND PROVIDENCE PLANTATIONS DEPARTMENT OF ADMINISTRATION DIVISION OP PLANNING

265 Melrose Street

Providence, Rhode Island 02907 


\section{CONTENTS}

Part

Page

1. Introduction

1.1

2. Septic System Maintenance

2.1

Septic Systems

2.1

Maintenance

2.1

Water Quality Problems

2.3

Solutions

2.3

3. Waste Water Management Districts

3.1

Administration

3.3

Staff

3.4

Septic System Inspection

3.4

Education

3.8

Financing

Financial Assistance

Enforcement

3.10

Septage Disposal

3.10 


\section{Appendicies}

Appendix A - An Act Relating To Septic System Maintenance

Appendix B - Model Ordinance - Waste Water Management District

Appendix C - Municipal Authority To Exceed DEM's ISDS Regulations

Appendix D - Sources Of Additional Information 


\section{PREFACE}

This report was prepared as one of a series of documents to support the Scituate Reservoir Watershed Management Plan. The impetus for this effort is a task force appointed by Governor Edward DiPrete to determine what measures should be taken within the watershed to protect the water quality of the Scituate Reservoir from the degradational effects of escalating development.

The primary goals of the task force are threefold:

1. Determine appropriate land uses, densities, and development controls necessary to protect drinking water quality from the effects of new growth.

2. Develop means to mitigate existing water quality contamination sources, and

3. Devise a management/regulatory structure necessary to oversee the implementation of the watershed protection plan.

Additional reports will be published that will address key issues as determined by the Task Force. The findings of these documents will be used to formulate the final recommendations for a comprehensive Scituate Reservoir Watershed Management Plan. 


\section{ACKNOWLEDGEMENTS}

This report was prepared by Scott Millar, Principal Environmental Planner with assistance from David Lavalle, a student intern under the general supervision of Victor J. Parmentier, Supervising Planner. Additional Division of Planning staff involved with the preparation of this report include:

Daniel W. Varin, Associate Director

Mark J. Vincent, Environmental Planner; and

Linda S. Conti, Word Processing Typist - who patiently typed and retyped numerous drafts.

The draft report was also reviewed by the following town planners whose comments have been incorporated into the final report:

Marilyn Cohen, North Kingstown

Clark Collins, Narragansett

Jim Kanes, Charlestown

Jennifer Parker, Jamestown

Anna Prager, South Kingstown

In addition Lorraine Joubert, from the DEM, reviewed the draft for its consistency with the DEM's ISDS regulations. 


\section{PART 1: INTRODUCTION}

In April 1986, a Task Force was organized by the Rhode Island Department of Environmental Management (DEM) to review and recommend revisions to the DEM's Individual Sewage Disposal System (ISDS) or Septic System Regulations. The Task Force, which was comprised of soil scientists, geologists, public health officials, builders, planners, environmental groups, and DEM staff, evaluated ISDS Regulations for the following:
1. location, design and construction of new systems,
2. maintenance and repair of existing systems,
3. application of innovative technology, and
4. public education.

The Task Porce completed its work in Decemer 1986, and issued a report which contained its findings and recommendations. A key Task Force finding was the inadequacy of the existing ISDS Regulations with respect to addressing the regular maintenance of septic systems. It was determined that the State did not have the resources to implement and enforce an ISDS maintenance program. Therefore, it was recommended that municipalities assume an active role in preventing septic system failures by establishing maintenance programs. The specific recommendations for maintenance were as follows:

1. Develop and seek passage of legislation authorizing municipalities to establish ISDS maintenance districts on a voluntary basis,

2. Prepare a model ISDS maintenance ordinance outlining specific standards and procedures for mandatory ISDS maintenance for adoption by communities establishing maintenance districts, and 
3. Expand public information and education efforts to encourage proper homeowner care of ISDS.

To address the Task Force's ISDS maintenance recommendations, the Division of Planning, with assistance from the DEM, developed enabling legislation which allows municipal governments to establish maintenance programs. This legislation, which is contained in Appendix A, was approved in the 1987 General Assembly Session and signed into law by Governor DiPrete in June.

The purpose of this report is to explain how a community can initiate a municipal septic system maintenance program including options for its administration, staff support, financing and enforcement. A model ordinance to assist with the implementation of a maintenance program has also been developed and is included in Appendix B. The intent is to provide a starting point, options for consideration, and a recommended program that a community can modify to suit their own needs. 


\section{PART 2: SEPTIC SYSTEM MAINTENANCE}

\section{Septic Systems}

Septic Systems or individual sewage disposal systems (ISDS) are generally an inexpensive and acceptable means of household waste water disposal. The biggest drawback to these systems is that they can fail to operate properly, creating a health concern and a possible water quality contamination source.

There are four factors that govern the proper operation and life expectancy of a septic system: 1) location; 2) design; 3) installation; ańd 4) maintenance. The first three are regulated by the Department of Environmental Management.

(1) Maintenance, since it is unregulated, has been severely neglected by many homeowners.

\section{Maintenence}

It has been well documented that an ISDS requires maintenance to operate properly. Maintenance means the cleaning or pumping out of an ISDS on a regular basis, approximately every three years. As can be seen in Figure 1, a septic system is comprised of the septic tank, distribution box, and leach field. Waste water enters the septic tank where solids settle to the bottom and excess liquid or effluent flows from the tank into a distribution box which evenly distributes the effluent into the leachfield. The waste water then percolates downward through the soil. Since most soil can be a good purifying medium, it can efficiently remove bacteria and viruses from household waste water if travel time through unsaturated soil is sufficient.

(1) It should be noted that the DEM ISDS regulations are minimum standards. Municipalities can establish more stringent criteria, if deemed necessary. Refer to Appendix $\mathrm{C}$ for further details. 
FIGURE I

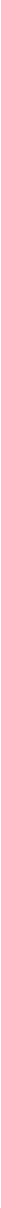


An ISDS fails when the solids from the septic tank accumulate to a level where they spill out into the leaching field and reduce the percolation capacity. This condition clogs the leachfield and causes untreated waste water to break out onto the ground surface or back up into the plumbing. To prevent this type of failure the solids in the septic tank must be pumped out regularly. When a leachfield becomes clogged expensive repairs are necessary to repair or replace the system.

\section{Water Quality Problems}

Waste water that breaks out onto the surface not only poses a severe localized health threat but can run off to contaminate adjacent surface waters. A less obvious but equally as serious form of failure occurs where there is an insufficient separation between the groundwater and the bottom of the leachfield. In this case, effluent may not rise to the surface but seep through the soil with little or no treatment, resulting in the discharge of bacteria, viruses, and high levels of nutrients in the form of nitrates to the groundwater. Homeowners who are served by private wells and septic systems may face the danger of having their drinking water contaminated without their knowledge.

\section{Solutions}

In the past, the standard solution to failing septic systems was to install public sewers. In large, densely populated communities, a municipal sewerage system may still be the most appropriate means for treating sewage. However, public sewers are extremely costly to install and are often beyond the means of most small or rural communities. In addition, the introduction of sewers to an area can stimulate unwanted development. For those communities that are unable to afford sewers and unwilling to ignore the problems associated with failed septic systems, the establishment of Waste Water Management Districts are a realistic alternative. 


\section{PART 3: WASTE WATER MANAGEMENT DISTRICTS}

Enabling legislation that was passed in the 1987 General Assembly Session allows Rhode Island municipalities to establish Waste Water Management Districts (WWMD). The purpose of these districts is to eliminate and prevent the contamination of state waters caused by malfunctioning ISDS through the implementation of inspection and maintenance programs. The adoption of an appropriate ordinance allows municipalities to:

1) Provide for the passage of district officials and septage haulers onto private property when necessary for the periodic inspection, maintenance, and correction of ISDS systems.

2) Raise funds for the administration, operation, contractual obligations and services of the Waste Water Management District by:

a) Assessing property owners for taxes or annual fees;

b) Borrowing, and for that purpose, by issuing bonds or notes of the city or town;

c) Setting rates for pumping.

3) Establish the necessary administrative, financial, technical, enforcement, maintenance, and legal structures to effectively implement and conduct Waste Water Management District programs, as well as hire the personnel necessary to support these structures.

4) Establish a public education program, which would precede the implementation of a WWMD, to make property owners aware of the proper maintenance and care of ISDS systems and the need for periodic pumping. After a WWMD has 
been created, an education program could remain in place to educate new residents and update members of the district on new information or procedures.

5) Receive grants and establish a revolving fund to make grants and low interest loans available to individual property owners for the improvement, correction, or replacement of failed septic systems.

6) Authorize and contract with independent septage haulers.

7) Contract with other cities or towns for septage disposal through sewage treatment plants.

8) Designate proper collection and disposal sites for septage collected by authorized pumping and hauling agents.

9) Levy fines for noncompliance. Such fines shall be no greater than $\$ 500$ per violation. Each day of a continuing violation shall constitute a separate and distinct violation.

A WWMD can be established for all or portions of a community. In addition, two or more municipalities may wish to jointly adopt a regional WWMD. Any area that is not served by public sewers should be considered for a WWMD. However, some areas that should be given a high priority for a WWMD include:

1) Homes served by on-site wells and septic systems;

2) Watersheds or aquifers that provide or have the potential to provide public drinking water; 
3) Areas with a history or strong potential for failed septic systems, such as areas with poorly drained soils; and

4) Sites adjacent to high quality surface waters.

A WWMD can be adopted in the same manner as other municipal ordinances. The town solicitor should be consulted to determine the proper procedures.

\section{Administration}

There are a number of options for the administration of a WWMD. The following are some alternatives for designating the responsibility for implementation.

1) Existing Sewer Authorities - Since sewer authorities already govern public sewers within the town it might make sense to give them the power to oversee ISDS maintenance.

2) Public Works Department '- An existing public works agency or town engineer could have the necessary technical expertise and administrative framework already in place.

3) New WWMD Commission - The town council could appoint a bi-partisan 5-7 member commission to implement the program. It would be helpful for commission members to have some knowledge in one or more of the following disciplines: engineering, soils, chemistry, biology, planning or education.

Since commissions are public bodies they are subject to the provisions of the R.I. open meetings law. Accordingly, meetings must be run with a few simple procedures: 
Votes must be by quorum, accurate records should be kept, and the meetings must be open to the public.

\section{Staff}

For a WWMD to be successful, full or part time staff are necessary to carry out the program. A district's operation has three components:
1) Septic System Inspection
2) Public Education
3) Office administration

There are several options on how to accomplish these three tasks. First, the district can hire either full or part-time staff to run the entire program. Second, the district can contract with a private contractor to assume all tasks. Finally, a combination of options one and two can be used. For example, the administrative and educational components could be performed by the town, with a private contractor hired to perform the inspections. Prior to making these decisions, the size of the WWMD should be considered, the frequency of inspections, the availability/experience of existing town personnel, and the availability and cost of private contractors. Caution should be exercised in assigning new duties to existing town staff that may already be overburdened.

\section{Septic System Inspection}

The inspection of an ISDS is the key component of a WWMD program. Whoever conducts the inspections must be adequately trained. The inspector must be able to recognize subtle, as well as flagrant signs of system failure. At a minimum, septic system inspections should include: 
1) Septic Tank Sludge Levels - the septic tank inspection port must be opened to examine the depth of sludge in the tank. When the sludge level accumulates to a depth of one third the distance to the leach field outlet or 16 inches in depth the tank should be pumped.

2) Surface Break Out - wastewater that "breaks out" onto the ground surface is an indication of failure.

3) Lush Plant Growth - Systems that have lush green grass growing over the tank or leachfield location are unlikely to be operating properly.

4) Odor - Strong sewage odors are an obvious indication oî a septic system malfunction.

5) Trees or Shrubs - There should be no trees or shrubs growing over or within 10 feet of the leachfield.

6) Impervious Area - There should not be any patios, driveways, swimming pools or other impervious surfaces over the leachfield without the approval of the DEM.

If the inspection reveals a malfunctioning system, the owner should be given a written notice indicating the probable cause and recommended corrective actions. The owner should be given a reasonable time frame (30 days) to contact the DEM and apply for the necessary permit to repair the system, if necessary. An additional time limit should be established, on a case by case basis, to complete all necessary repairs. 
If a system has not failed, but requires pumping, the owner should be required to show proof that the ISDS has been pumped within thirty days of the inspection. A receipt from the pumper can be used as adequate proof.

ISDS owners should be cautioned about having their systems pumped during the wet season, (December-March) particularly in areas with seasonally high water tables. A concrete septic tank is water tight and can become buoyant after the solids are pumped out. A high water table could either push an empty tank out of the ground or tilt it in the ground so that the waste water will not effectively flow into the leaching field.

Instead of an inspector measuring septic tank sludge levels, a district can automatically require that all tanks be pumped on a regular basis such as every three years. This requirement should be staggered through the district so that everyone does not need to have their system pumped in the same year. To encourage compliance, the district may wish to of fer a rebate to subsidize some or all of the homeowner's pumping costs. An annual ISDS owner maintenance fee could be a source of funds for the rebate program.

Another option would be for the District to enter into a contractual agreement with a private firm to have all systems automatically pumped every three years, or as needed. For example if an ISDS costs $\$ 75$ to be pumped once every three years, a WWMD could assess an ISDS owner $\$ 25$ per year plus an administrative charge to fund District operations. This option may prove to be the most desirable for the following reasons:

1. Complete compliance with District pumping requirements would be assured.

2. An efficient and orderly pumping schedule can be established to avoid over loading septage receiving facilities. 
3. It will be easier to keep maintenance records.

4. Septage can be more readily traced to insure proper disposal.

5. ISDS owners could be eligible for a reduced group rate from private pumpers.

6. The District can be sure that ISDS pumpers are properly trained and licensed.

(NOTE: All septage haulers are required to maintain records indicating the source and estimated volume of septage picked up, the date of shipment, and the name of the facility where the septage was discharged.)

The frequency of inspections should be determined by the nature of the WWMD. As a rule of thumb, an ISDS should be inspected on an annual basis. Inspections conducted at a rate less than this may not identify problems in a timely manner. Some systems, such as those located in areas prone to failures or vacation rental units will need more frequent inspections than once a year. This frequency can be established by the WWMD as needed.

Property owners should be notified of inspection schedules. This can be done by direct mailings, an advertisement in the local newspaper or a notice posted in the town hall and other municipal buildings. The mail is the best way to insure that homeowners have been notified but it is also the most costly. The newspaper could be a less expensive alternative, and a posted notice should only be used to supplement the first two options.

Regardless, of the maintenance requirements selected by a WWMD, it is imperative that accurate and up-to-date records be kept. A record card system could be established that would indicate the following:
1) Owner's name;
2) Street address or utility pole number; 
3) Telephone number;

4) ISDS location, and age, if known; (The ISDS location should be mapped once it has been located.)

5) Date of last maintenance; and

6) Notes on the condition of the ISDS.

\section{Education}

Public education is a critical part of any waste water management program. The first thing that any potential district is going to confront is the "what-I-do-on-myproperty-is-my-business" attitude. People have to be convinced that the pollution caused by malfunctioning septic systems is not a problem that can be confined to a single property but, rather, is one that affects the entire community. It is much cheaper for a municipality to rely on septic systems than to install public sewers and assess homeowners for the expense. In addition, homeowners who are served by on-site wells and ISDS need to practice proper maintenance to safeguard their drinking water supplies.

Pamphlets, such as the one produced by Save the Bay, public information meetings, and newspaper articles are some of the means of reaching the community and explaining what a waste water management program is all about.

The district also needs to have an ongoing program to educate residents on the operation and maintenance of septic systems. For example, a simple fact about septic systems is that the less water going through a system the better it will operate. Devices that reduce water flow can be installed on faucets, showers, and toilets. The district should make residents aware of how these water restriction devices can improve the operation of their system. With an effective education program, the district can reduce the number of problems that residents encounter. 


\section{Financing}

As previously mentioned, the enabling legislation empowers municipalities to raise funds for the administration and operation of the district. There are a number of options that municipalities can consider to establish an operating budget. However, one simple and equitable means would be to assess each homeowner within the district an annual flat fee based on the number of dwelling units owned. Since commercial and industrial septic systems may need more time-consuming and frequent inspections, a higher fee could be assessed. In addition, any residential site requiring more than two inspections per year could also be assessed an extra fee for each subsequent visit.

There are several options for establishing the rate for the annual flat fee. It could either be based on what is neccessary to support the district yearly operating costs or, to develop a reserve fund which could be used to assist needy homeowners with repairs or pumping fees.

\section{$\underline{\text { Financial Assistance }}$}

Some septic systems will be beyond the scope of maintenance and will need to be replaced. A situation that a WWMD is likely to encounter is when a homeowner with a failed ISDS cannot afford to repair it. In these situations, the district has the authority to issue bonds to obtain funds that can be allocated as either grants or low interest loans to assist qualified individuals.

It may be the case that an entire neighborhood needs ISDS repairs and the site is not suitable for conventional septic systems. In this case, it may be necessary to design an expensive community system to solve the problem. The WWMD may wish to offer financial aid to such a neighborhood to effectively mitigate the problem. 


\section{Enforcement}

The effectiveness of any ordinance is only as good as its enforcement. A WWMD has the authority to take some strong enforcement measures if necessary. The district may levy fines for noncompliance, which can go as high as $\$ 500$ per day.

\section{Septage Disposal}

A key factor to consider prior to implementing a septic system maintenance program is the proper disposal of septage, or the solid/riquid contents that are pumped out of the septic tank. Septage is required to be taken to a waste water treatment facility for treatment. However, municipal treatment facilities are limited in the amount of septage that they can adequately accomodate. In addition a community with a treatment facility is only obligated to accept septage from within its own service area. For example the city of Cranston may but is not required to accept septage from the town of Scituate, which is not served by municipal sewers.

It is extremely important for a municipality, that does not have public sewers to establish an agreement with a municipal waste water treatment facility for septage disposal. Communities that have sewage treatment must exercise caution to prevent overloading the capacity of their treatment facilities. The failure to plan for septage disposal could encourage illegal septage dumping which could pose an even greater environmental threat than the problem of inadequate septic system maintenance.

Clearly the septage disposal problem is one that must be resolved before the adoption of large scale community maintenance programs. The Department of Environmental, with assistance from the Division of Planning, is currently working to assist municipalities with this issue. 


\section{Conclusion}

Waste Water Management Districts are a realistic and affordable solution to the problems of failing septic systems. Proper maintenance benefits homeowners and the community both environmentally and economically. Although a WWMD may require some hard work to establish, the payoff benefits everyone. 


\section{APPENDIX A}

\section{ST A T E OF RHODE ISLA N D}

IN GENERAL ASSEMBLY

JANUARY SESSION, A.D. 1987

\section{A N A C T \\ RELATING TO THE SEPTIC SYSTEM MAINTENANCE}

It is enacted by the General Assembly as follows:

SECTION 1. TITLE 45 OF THE GENERAL LAWS ENTITLED "TOWNS AND CITIES" IS HEREBY AMENDED BY ADDING THERETO THE FOLLOWING CHAPTER:

CHAPTER 24.5

WASTE WATER MANAGEMENT DISTRICTS

45-24.5-1. Short Title. - This chapter shall be known and may be cited as the "Rhode Island Septic System Maintenance Act of 1987."

45-24.5-2. Legislative findings. - The general assembly hereby recognizes and declares that:

Septic systems or individual subsurface disposal systems (ISDS) are prone to failure without proper maintenance. ISDS failure poses a risk to public health through the contamination of the state's surface and underground waters. Improperly treated waste water from malfunctioning ISDS can impair or prevent the use of the state's waters for drinking and domestic purposes, as well as swimming, wildlife habitat, boating, fishing and other water-based recreation. In many suburban and rural areas of the state, the use of ISDS is the only practical or available means to treat waste water. Most community and individual water supplies and some of the state's prime recreational waters are located in areas that rely on ISDS. Recreational and drinking supply waters are the least tolerant of 
vaste water contamination and, therefore, require rigorous protection. ISDS will :ontinue, for the near term, to be the primary means of waste water treatment in many areas of the state where public and private water supplies and recreational waters exist. Therefore, to help avoid both contamination of state waters and the associated risks to the public health and help preserve the natural ecosystems, waste water disposal systems must be properly maintained to prevent their malfunction and/or failure.

45-24.5-3. Declaration of purpose. - The purpose of this chapter is to authorize the cities and towns of the state to adopt ordinances creating Waste Water Management Districts (WWMD), the boundaries of which may include all or part of a city or town, as specified by such ordinance. Such ordinances shall be designáted to eliminate and prevent the contamination of state waters, caused by malfunctioning individual subsurface disposal systems (ISDS), through the implementation of ISDS inspection and maintanence programs. The waste water management district ordinance programs shall be designed to operate as both an alternative to municipal sewer systems and as a method to protect surface and ground waters from contamination.

45-24.5-4. Powers of councils. - The city or town council of any city or town in the state, by itself or pursuant to chapter $45-43$, and in accordance with the purposes of this chapter, are hereby authorized to adopt ordinances creating Waste Water Management Districts (WWMD), which may be empowered, pursuant to such ordinance, to:

(a) Provide for the passage of District officials onto private property when necessary for the periodic inspection of septic systems.

(b) Order the maintenance and/or pumping of ISDS systems in accordance with an appropriate schedule.

(c) Raise funds for the administration, operations, contractual obligations and services of the Waste Water Management District by:

1. Assessing property owners for taxes or annual fees;

2. Borrowing, and for that purpose, by issuing bonds or notes of the city or town; 
3. Setting rates for pumping.

(d) Hire the personnel necessary to carry out the functions of the district.

(e) Establish a public education program, which would precede the implementation of a WWMD, to make property owners aware of the proper maintenance and care of ISDS systems and the need for periodic pumping. After a WWMD has been created, an education program could remain in place to educate new residents and update members of the district on new information or procedures.

(f) Receive grants and establish a revolving fund to make available grants and low interest loans to individual property owners for the improvement, correction or replacement of failed septic systems.

(g) Authorize and contract with independent septage haulers.

(h) Contract with other cities and towns for septage disposal through sewage treatment plants.

(i) Levy fines for non compliance. Such fines shall be no greater than $\$ 500$ per violation. Such fines shall go into a dedicated fund for the purpose of operating the Waste Water Management District. Each day of a continuing violation shall constitute a separate and distinct violation.

(j) Provide for an appeal process from the decision of the WWMD under the provisions of the Rhode Island Administrative Procedure Act. An aggrieved party shall have the right to appeal to the District Court.

45.24.5-5. Powers of the State agencies retained. - The Departments of Environmental Management and Health shall retain all of their existing authority regarding individual sewage disposal systems.

SECTION 2. This act shall take effect upon passage. 


\section{EXPLANATION}

OF

AN ACT

\section{RELATING TO SEPTIC MAINTENANCE}

cts to oversee the maintenance of existing septic systems.

This act shall take effect upon passage. 


\section{APPENDIX B \\ MODEL ORDINANCE \\ Waste Water Management District}

\section{Section 1.0 Purpose}

The city or town council hereby finds that, without proper operation and maintenance, Individual Sewage Disposal Systems (ISDS) or septic systems are prone to failure. ISDS failure poses a risk to public health and a potential contamination source to the surface and ground waters of the State. The purpose of this ordinance is to establish a Waste Water Management District (WWMD), in accordance with the provisions of Chapter 45-24.5 of the Rhode Island General Laws, to ensure that ISDS are properly operated, regularly inspected, and routinely maintained to prevent malfunctioning systems and to operate as an alternative to municipal sewer systems.

\section{Section 2.0 Definitions}

\subsection{Alteration}

An alteration is any change in size or type of system, or installation of a replacement system.

\section{$2.2 \quad$ Failed System}

Any sewage disposal system that does not adequately treat and dispose of sewage so as to create a nuisance or threat to public health and/or environmental quality, as evidenced by, but not limited to, the following conditions: 
a. Failure of a system to accept waste water discharge or backup of waste water in to the building sewer.

b. Discharge of waste water directly or indirectly to a subsurface drain, surface drain, or surface water.

c. Effluent rising to the surface of the ground over or near any part of the septic system or downgrade from the absorption area at any change in grade, bank, or road cut.

d. Discharge of improperly treated effluent to groundwater including but not limited to inadequate separation from the bottom of the leaching system to groundwater or impervious layer and resulting in contamination of ground or surface water.

e. Condition of deterioration, damage, or improper design, to any ISDS that would preclude adequate treatment and disposal of waste water.

f. Pumping records that indicate very frequent maintenance. A system shall be considered in need of repair or alteration if the system has been pumped, or in need of pumping, four or more times in a period of one year.

\subsection{Individual Sewage Disposal System (ISDS)}

An individual sewage disposal system shall be a system installed to provide sanitary sewage disposal by means other than discharge into a public sewer system.

\subsection{Leachfield}

A subsurface area from which septic tank effluent or waste containing little or no solids is leached into the soil. 


\subsection{Maintenance}

The inspection on a regular basis of the ISDS and as necessary the cleaning out or pumping of accumulated scum and sludge from any septic tank, building sewer, or any other component of an ISDS that can be cleaned or pumped.

\subsection{Owner}

Owner is any person who alone, or jointly, or severally with others (a) has a legal title to any premises, or (b) has control of any premises, such as agreement of purchase, agent, executor, executrix, administrator, administratrix, trustee, lessee or guardian of the estate of a holder of a legal title. Each such person is bound to comply with the provision of this ordinance.

\subsection{Person}

The term person shall include any individual, group of individuals, firm, corporation, association, partnership or private entity, including a district, city, town or other government unit or agent thereof, and in the case of a corporation, any individual having active and general supervision of the properties of such corporation.

\subsection{Repair}

To mend, remedy, renovate, or restore to a sound state after injury, deterioration, partial destruction or, to replace a septic tank, distribution box, leachfields or pipes connecting any of these, with no change in type of material, location, or area of an ISDS. 


\subsection{Sanitary Sewage}

Any human or animal excremental liquid or substance, any putrescible animal or vegetable matter, garbage and filth, including the discharge of water closets, laundry tubs, washing machines, sinks, dishwashers and the contents of septic tanks, cesspools or privies.

\subsection{Septage}

Septage is the solid or liquid materials which are pumped from an ISDS.

\subsection{Septic System}

For the purpose of this ordinance a septic system is analogous to an individual sewage disposal system. Refer to section 2.3

\subsection{Septic Tank}

A septic tank is a water tight receptacle which receives the discharge of sanitary sewage and is designed and constructed to permit the deposition of settled solids, the digestion of the matter deposited, and the discharge of the liquid portion into a leaching system.

\subsection{Waste Water}

Waste water is analogous to sanitary sewage. Refer to section 2.9 . 


\subsection{Waste Water Management District}

A Waste Water Management District (WWMD) is all or a portion of one or more cities or towns where the proper operation and maintenance of an ISDS will be required in accordance with the provisions of an adopted ordinance, which defines the district.

\section{Section 3.0 Applicability}

This ordinance shall be applicable to every owner of premises that has an Individual Sewage Disposal System located within the designated boundaries of the Waste Water Management District.

\section{Section 4.0 Waste Water Management District Boundaries}

The Waste Water Management District will regulate the operation and maintenance of all ISDS within - (specify the entire municipality, portion thereof, or a regional district including all or portions of two or more municipalities.)

\section{Section 5.0 Regulations for ISDS Operation and Maintenance}

\subsection{Pumping of Individual Sewage Disposal Systems}

The contents of all ISDS within the WWMD shall be inspected and as necessary pumped out (within 2 years of the effective date of these regulations and every three years thereafter or as required.) Such pumping shall be performed by municipal employees or private operators duly authorized by the WWMD. 
Additional pumpings may be required as deemed necessary by the WWMD for the proper operation of an ISDS.

\subsection{Septage Disposal}

Septage or contents pumped from an ISDS shall be discharged at a waste water treatment facility approved by the Department of Environmental Maragement for this purpose. (NOTE: A WWMD shall make arrangements for the proper disposal of septage at an approved waste water treatment facility.)

\subsection{Improper Discharges to ISDS}

The discharge of rain spouts, basement sumps, or any other drains to an ISDS, with the exception of washing machines, is prohibited.

\subsection{Acid and Organic Chemical Septic Tank Additives}

The use or disposal of acids or any organic chemical solvents in an ISDS is prohibited, unless these can be sufficiently demonstrated to have a beneficial effect on ISDS operation and no adverse impacts to the environment.

\subsection{Impervious Surfaces}

The location of swimming pools, patios, driveways or other impervious surfaces over leaching areas is prohibited without the approval of the Department of Environmental Management. (NOTE: The WWMD may wish to consider variances for unusual circumstances.) 


\subsection{Garbage Disposals}

Garbage disposal discharges to an ISDS shall be discouraged, since they add unecessary solids to an ISDS, and installed in accordance with DEM ISDS regulations.

\subsection{Trees and Shrubs}

The owner shall keep trees and shrubs at a minimum of 10 feet from the leaching area to keep roots from clogging or disrupting the ISDS.

\subsection{Acessibility}

The owner shall maintain ISDS so that it is accessible for inspection and maintenance.

\section{Section 6.0 EDS Inspections}

This ordinance authorizes the passage of City, Town or WWMD officials or their designees and septage haulers onto private property when necessary for the periodic inspection, maintenance and repair of ISDS.

\subsection{Inspection Frequency}

All ISDS shall be subject to an on-site inspection by the WWMD or its designee on an annual basis. More frequent inspections may be conducted if deemed necessary by the WWMD. All ISDS owners shall be sent a written notice of inspection schedules.

B.7 


\subsection{Inspection Records}

The WWMD shall maintain a record of each ISDS inspected including:

- Owner's name

- $\quad$ Street address or utility pole number

- Telephone number

- ISDS location (NOTE: A rough sketch map will assist in locating the system in subsequent years)

- Date(s) of previous maintenance

- Notes on ISDS condition

\subsection{Inspection Reports}

A written report detailing the results of the inspection shall be kept on file with the WWMD. If the inspection reveals a malfunctioning ISDS, the owner shall be given a written notice indicating the probable cause and recommended corrective actions. A copy of said report shall also be sent to the DEM Division of Land Resources. The owner shall be given (30 days) to contact the DEM and apply for a permit to repair or replace the system, if necessary. A time limit to complete any needed repairs shall be established on a case by case basis.

If a system has not failed but requires pumping, the owner shall be required to show proof that the ISDS has been pumped within (30) days of the inspection. A receipt from the pumper shall constitute adequate proof. 


\section{Section 7.0 Administration}

Upon the adoption of this ordinance the (city/town council) shall establish an adininistrative framework necessary to implement the provisions of Chapter 45-24.5 and this ordinance. Refer to Waste Water Management Districts... A Starting Point for administrative options.

\section{Section 8.0 Education}

It shall be the responsibility of the WWMD to establish a public education program to make ISDS owners aware of the proper operation and maintenance of these syster.s.

\section{Section 9.0 Financing}

\subsection{Fee Structure}

The WWMD shall have the authority to raise funds for the administration, operation, contractual obligations and services of the WWMD. (An annual service fee of dollars will be assessed to each owner of an ISDS based on the number of these systems owned in the WWMD.)

\subsection{Grant or Loan Program}

The WWMD shall have the authority to issue bonds or notes of the (city or town) and receive grants for the purpose of establishing a revolving fund to make low interest loans or grants available to qualified property owners for the improvement, correction, or replacement of failed ISDS. The WW MD shall establish 
specific criteria that shall be subject to comments from a public hearing prior to implementing a loan or grant program. (NOTE: The criteria for the DEM sewer and water failure fund program could serve as a guide.)

\section{Section 10.0 Enforcement}

\subsection{Enforcement Responsibility}

The WWMD shall be responsible for enforcing the provisions of this ordinance.

\subsection{Notice of Violations}

Any owner of an ISDS determined to be in violation of these regulations will be issued a written notice explaining the nature of the violation, required actions, a reasonable time frame for compliance, and the possible consequences for noncompliance.

\subsection{Hearing}

Any owner receiving a written notice of violation shall be given an opportunity, within a reasonable time frame, for a hearing before the WWMD to state their case. If the evidence indicates that a violation has not occurred, the WW MD shall revoke the notice of violation. 


\subsection{Penalties}

Any person neglecting or refusing to comply with a written notice of violation issued under the provisions of this ordinance shall be fined not more than $\$ 500$ per violation. Each day of a continuing violation shall constitute a separate and distinct violation.

(NOTE: A WWMD could correct a serious violation of this ordinance and place a lien on the violators property to recover the costs for any necessary pumping, repairs, and/or the replacement of an ISDS determined to be in violation following the procedures of Section 10.2 and 10.3.)

\section{Section 11.0 Severability}

If any provision of this ordinance or any rule or determination made hereunder, or application hereof to any person, agency, or circumstances is held invalid by a court of competent jurisdiction, the remainder of this ordinance and its application to any person, agency, or circumstance shall not be affected thereby. The invalidity of any section or sections of this ordinance shall not affect the validity of the remainder of the ordinance. 


\section{APPENDIX C \\ MUNICIPAL AUTHORITY TO EXCEED DEM'S ISDS REGOLATIONS}

The Department of Environmental Management's Individual Subsurface Disposal System (ISDS) regulations have been established as minimum criteria for the location, design, and construction, of ISDS. The Rhode Island Supreme Court ruled that "clearly the intent of chapter 131 was to grant municipalities the option of providing additional restrictions concerning the construction of individual waste-water facilities." This decision was rendered in the case of Gara Realty, Inc. versus the Town of South Kingstown's Zoning Board of Review in April, 1987.

The complete text of this Supreme Court decision follows:

GARA REALTY, INC.

v.

THE ZONING BOARD OF REVIEW OF THE TOWN OF SOUTH KINGSTOWN ET AL.

\section{O P I N ION}

MURRAY, J. This case is before the court on a writ of certiorari issued to review a Superior Court judgement affirming a decision of the Zoning Board of Review of the Town of South Kingstown. The review board denied the petitioner's application for a variance

1. Chapter 131 Section 6 of the Rhode Island Public Laws gives the DEM the authority to promulgate ISDS regulations. 
to install a sewage-disposal system closer to an intertidal waterway than is allowed under article 3, section 308 of the Zoning Ordinances of the Town of South Kingstown.

The property involved is located at Peninsula Road, Matunuck, Rhode Island, and recorded as lot No. 124 , map No. 68 , block 121. It is zoned R-20 under South Kingstown's zoning ordinances which permits, among other uses, construction of single-family dwellings.

The petitioner, Gara Realty, Inc., purchased the lot in 1980. Thereafter, petitioner applied to the building inspector for a building permit to construct a single-family dwelling on the lot. Because the lot size precluded the possibility of constructing a sewage-disposal system 150 feet from Potter Pond as required by article 3, section 308, of the Zoning Ordinances of the Town of South Kingstown, the building inspector denied petitioner's application.

In a letter dated Februrary 17, 1982, the building inspector advised petitioner to obtain a variance from the zoning board of review. The review board denied petitioner's request for a variance, and petitioner appealed to the Superior Court. In a bench decision rendered on November 28, 1984, the Superior Court judge affirmed the review board's decision. This petition for certiorari followed.

The petitioner presents several issues for review by this court: first, whether G.L. 1956 (1977 Reenactment) section 42-17.1-2, as amended by P.L. 1978, ch. 131, section 6, supersedes article 3, 308, of the South Kingstown zoning ordinances; second, whether the review board applied an erroneous standard for review of petitioner's request for a variance; third, whether the decision of the review board is substantially out weighed by the evidence presented; and fourth, whether the review board violated petitioner's rights under the United States and Rhode Island Constitutions. 
In reviewing an action of a zoning review board, the Superior Court "must examine the entire record to determine whether 'substantial' evidence exists to support the board's findings." DeStefano v. Zoning Board of Review of Warwick, 122 R.I. 241, 245, 405 A.2d 1167, 1170 (1979). On certiorari, we determine whether competent legal evidence supports the decision of the Superior Court. Id.

The petitioner argues that section 42-17.1-2, as amended by P.L. 1978, ch. 131, section 6 , supersedes article 3 , section 308 , of the South Kingstown zoning ordinances as a matter of law. Section $308(B)$ of the zoning ordinances provides that:

"No disposal trench, disposal bed, cesspool, seepage pit or other
facility designed to leach liquid wastes into the soil shall be
located within 150 feet of an intertidal salt marsh or within 150
feet of the line of mean high water of any tidal water body as
defined in regulations adopted by the Coastal Resources
Management Council of the State of Rhode Island and subsequent
amendments thereto."

Public Laws 1978, ch. 131, section 6 provides in part that it is the perogative of the director of environmental management, "to establish minimum standards, subject to the approval of the environmental standards board, relating to the location, design, construction and maintenance of all sewage disposal systems." The Department of Environmental Management Rules and Regulations Establishing Minimum Standards Relating to Location, Design, Construction, and Maintenance of Individual Sewage Disposal Systems, SD 2.16 (1980), provides for separate approval of "individual sewage disposal systems that are located within fifty $(50)$ feet of a marsh, swamp, bog or pond."

The petitioner contends that the state provisions conflict with section 308 , rendering it inoperative. The petitioner relies on Wood v. Peckham, 80 R.I. 479, 98 A.2d 669 (1953), for the proposition that where the State Legislature has sought to regulate a particular area, a municipality cannot regulate the same conduct. 
The petitioner's reliance on Wood is misplaced. Regulation SD 2.16 merely sets forth "minimum" requirements for the construction of septic systems which are to be located on property adjacent to an intertidal waterway. Clearly the intent of chapter 131 was to grant municipalities the option of providing additional restrictions concerning the construction of individual waste-water facilities. It was, therefore, the perogative of the town of South Kingstown to create more restrictive requirements, such as the 150 -foot setback regulation set forth in section 308. Consequently, we affirm the decision of the trial court upholding the validity of section 308 .

The petitioner next argues that the trial court "erred in holding that it had the burden of proving "unnecessary hardship" in order to obtain the variance. We agree.

In order to determine whether petitioner sustained its burden of proof before the zoning review board, it is necessary to determine what is the appropriate standard of proof. The burden is dependent upon the nature of the relief sought. We have previously distinguished between three types of relief which are commonly available in certain circumstances. They are a variance, a deviation, and an exception.

When a landowner seeks to use the land for a purpose not ordinarily permitted, a variance must first be obtained. To obtain a variance, one must satisfy the "unnecessary hardship" standard of G.L. 1956 (1980 Reenactment) 45-24-19(c), which requires "a showing of deprivation of all beneficial use of property **" Rozes v. Smith, 120 R.I. $515,519,388 \mathrm{~A} .2 \mathrm{~d} 816,819$ (1978). "(T)his standard is to be applied only to 'true variances' or those situations in which the proposed use of the property varies from any of the uses permitted under the ordinance." Id. 
A deviation defines the type of relief available from restrictions governing a permitted use, such as area or setback restrictions. DeStefano, 122 R.I. at 246, 405 A.2d at 1170. To obtain relief, one "need only demonstrate an adverse impact amounting to more than a mere inconvenience." Id. This standard was first enunciated in Viti v. Zoning Board of Review of Providence, 92 R.I. 59, 166 A.2d 211 (1960), and is known as the Viti doctrine.

An exception is similar to a deviation in that it pertains to requested relaxation of area and setback requirements for a permitted use. In order to obtain an exception, one "need show only that 'neither the proposed use nor its location on the site would have a detrimental effect upon public health, safety, welfare and morals."' Toohey v. Kelday, 415 A.2d 732, 736 (R.I. 1980) (quoting Hester v, Timothy, 108 R.I. 376, 385-86, 275 A.2d $637,641-42(1971)$.

The type of relief sought in the case at bar is more akin to a deviation than to a true variance. This is because petitioner seeks relief from a setback requirement of a permitted use. The property is zoned for single-family dwellings. The petitioner seeks to build a single-family dwelling on the lot. Certainly the zoning board envisioned wastewater facilities as an accompanying permitted use on property zoned residential. Therefore, petitioner was not required to demonstrate total deprivation of all beneficial use of the land in order to obtain relief. Reynolds v. Zoning Board of Review of Lincoln, 96 R.I. 340, 191 A.2d 350 (1963). Rather, petitioner needed only to demonstrate "that the effect of such enforcement (would) amount to something more than a mere inconvenience." Rozes v. Smith, 120 R.I. at 519, 388 A.2d at 819.

Clearly petitioner has met its burden of proof. The construction of any singlefamily dwelling requires an accompanying means of sewage disposal. Because section 308 
totally bars placement of such facilities on the premises at issue, enforcement of the ordinance effectively operates to preclude petitioner from building a house. We believe that this deprivation amounts to more than a mere inconvenience as a matter of law. We therefore believe that the trial court erred in denying petitioner relief. ${ }^{1}$

For these reasons we need not address the other issues raised in the petitioner's brief.

The petition for certiorari is granted, the decision of the Superior Court is quashed, and the case is remanded with instructions to grant the petitioner's request for a variance. Supreme Court No. 85-45-M.P. April 3, 1987.

1 Nothing herein should be construed to preclude the necessity on the part of the applicant to meet state sanitary standards.

\section{EXPLANATION}

Although the Town of South Kingstown was determined to have the authority to exceed the DEM's minimum ISDS standards, in this case the court ruled that Gara Realty Inc. must be granted an exemption from the 150 -foot setback since they were eligible for a "deviation" of the zoning setback requirement. As stated in the Supreme Court decision, a deviation can be granted to a property owner who is seeking "relief from zoning restrictions governing a permitted use, such as setback requirements." Since the town established the construction of a home and an ISDS as a permitted use, the plaintiff was eligible for a deviation when a "mere inconvience" (the preclusion of building a home) was demonstrated. 
The key words in this decision are "permitted use." If, for example, the town had established the construction of an ISDS within a 150 foot setback from a waterbody as a prohibited use that would only be allowed as a special exception, the court more than likely would have reached a different opinion.

A special exception is similar to a deviation in that it pertains to the relaxation of area and setback requirements. The major difference being that the granting of an exception requires one to prove that neither the proposed use nor its location on the site would have a detrimental effect upon public health, safety, welfare, and morals. If Gara Realty Inc. were required to seek relief from the 150 foot setback requirement by means of an exception rather than a deviation, substantial documentention would have had to be provided to prove that the proposed ISDS would not be a public health or safety problem. The burden of providing such evidence is clearly more difficult than demonstrating a "mere inconvience" as is the only requirement to obtain a deviation.

The Town of Narragansett, recently adopted a new zoning ordinance which establishes more stringent criteria for the location and construction of an ISDS. This was accomplished by establishing different overlay districts that prohibit the use of an ISDS within 200 feet of certain coastal waters and in areas with a high watertable. An ISDS would only be permitted in these areas through a special exception.

A "High Watertable Limitations Overlay District" composed of areas in which the watertable is within three feet below the surface ${ }^{1}$ of the ground for significant periods of the year was established and identified by soil types that were mapped as part of a town

1 The DEM has this same requirement but will grant approval, via an applicant appeals procedure, if the watertable is within two feet below the ground surface. 
environmental inventory. Within this overlay district ISDS are listed as prohibited uses that would be allowed only as a special exception pending a site plan review, an approved DEM ISDS permit and the conformance with designated town development standards.

A "Coastal Resources Overlay District" which encompasses an area within 200 feet of a coastal feature prohibits all uses and only allows certain uses as special exceptions providing compliance with town development standards. An ISDS is not permitted even as a special exception, within 200 feet of certain coastal waters. For more specific information regarding these overlay districts refer to the Town of Narragansett's Zoning Ordinance.

In conclusion, it is apparent that municipalities can require more stringent requirements than the DEM ISDS Regulations. However, specific procedures must be closely followed in doing so. 


\section{APPENDIX D}

\section{Additional Information Sources}

1) Septic System Regulations - contact the Department of Environmental Management, 75 Davis Street, Providence, RI 02908, 277-2306

2) Septic System Brochures - contact Save The Bay, 434 Smith Street, Providence, RI, 272-3540

3) Questions Regarding WWMD - contact Scott Millar, Division of Planning, 265 Melrose Street, Providence, RI 02907, 277-2656 
$\begin{array}{lllllllll}A & P & P & E & N & D & I & X & B\end{array}$ 
$\begin{array}{lllllllll}A & P & P & E & N & D & I & X & C\end{array}$ 
FIGURE 2: PAWTUXET RIVER DRAINAGE BASIN WITH

SUBDRAINAGE AREAS SHADED ACCORDING TO THE

AVERAGE CALCULATED RUNOFF-BORNE LOADING RATE OF

BIOLOGICAL OXYGEN DEMAND (LB/ACRE/YR)

\section{GLOCESTER}

FIGURE 3: PAWTUXET RIVER DRAINAGE BASIN WITH SUBDRAINAGE AREAS SHADED ACCORDING TO THE AVERAGE CALCULATED RUNOFF-BORNE LOADING RATE JF TOTAL PHOSPHATE (LB/ACRE/YR)

\section{GLOCESTER}
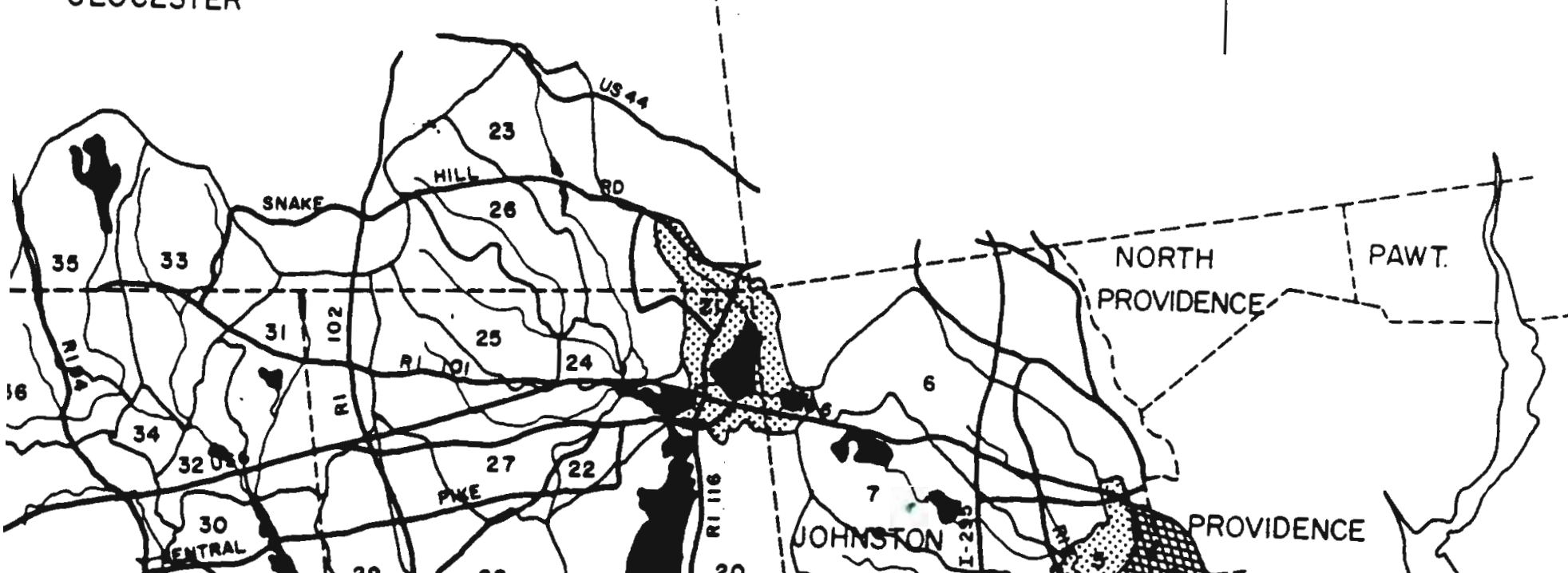
EIGURE 4: PAWTUXET RIVER DRAINAGE BASIN WITH SUBDRAINAGE BASINS SHADED ACCORDING TO THE AVERAGE CALCULATED RUNOFF-BORNE LOADING RATE T COPPER (LB/ACRE/YR)

\section{GLOCESTER}

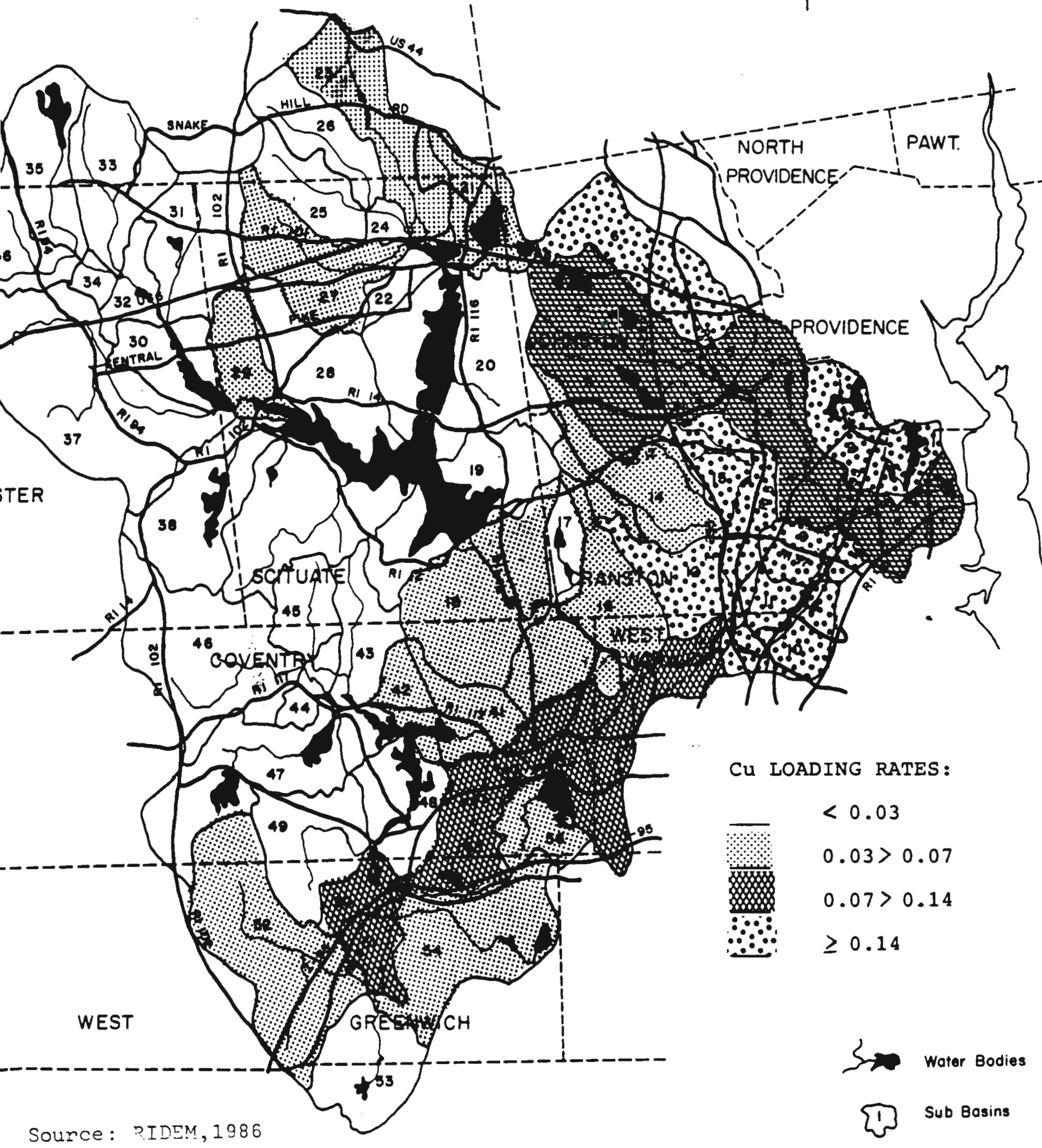


FIGURE 5* PAWTUXET RIVER DRAINAGE BASIN WITH SUBDRAINAGE AREAS SHADED ACCORDING TO-THE AVERAGE CALCULATED RUNOFF-BORNE IOADING RATE OF LEAD (LB/ACRE/YR)

\section{GLOCESTER}
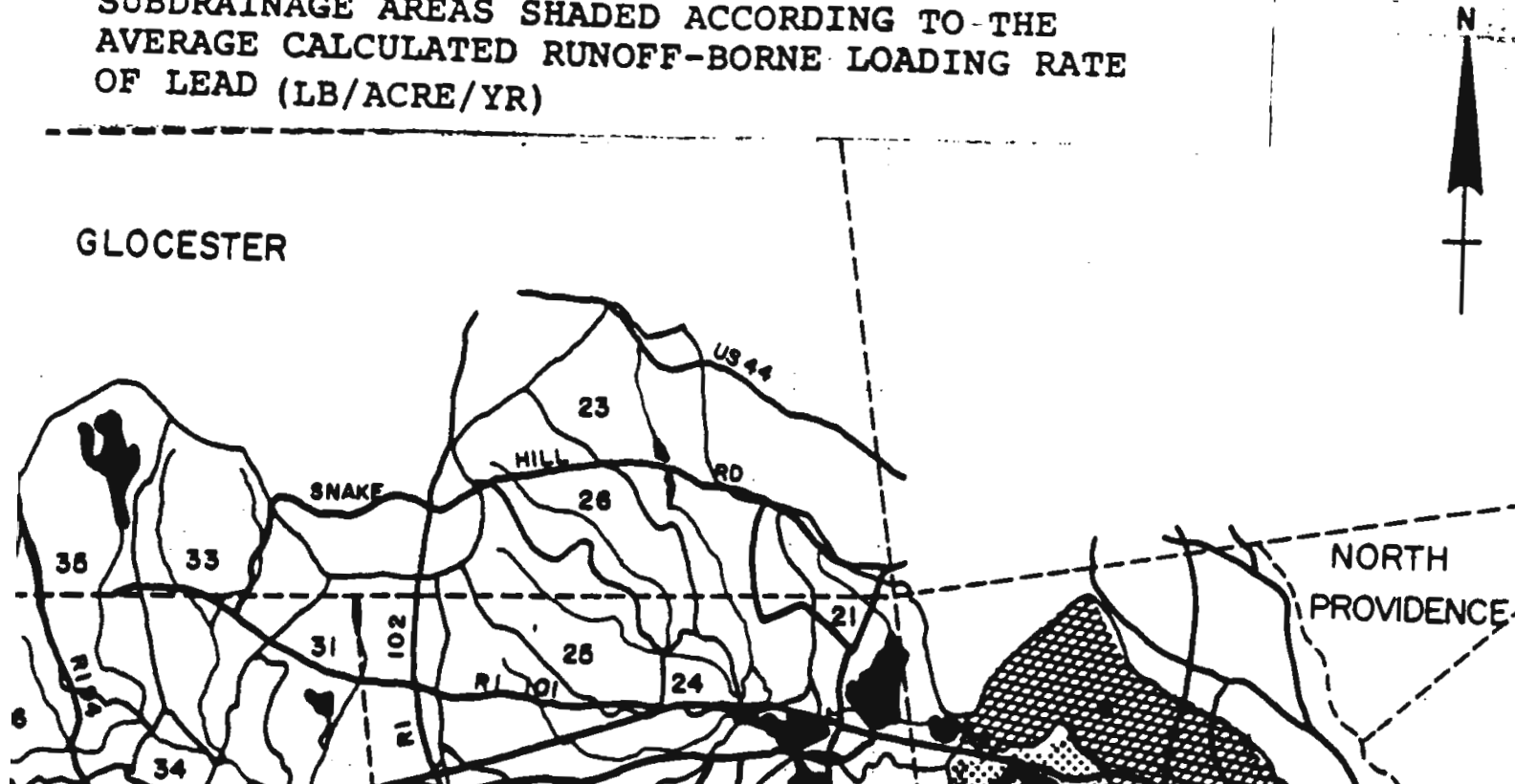

TEF
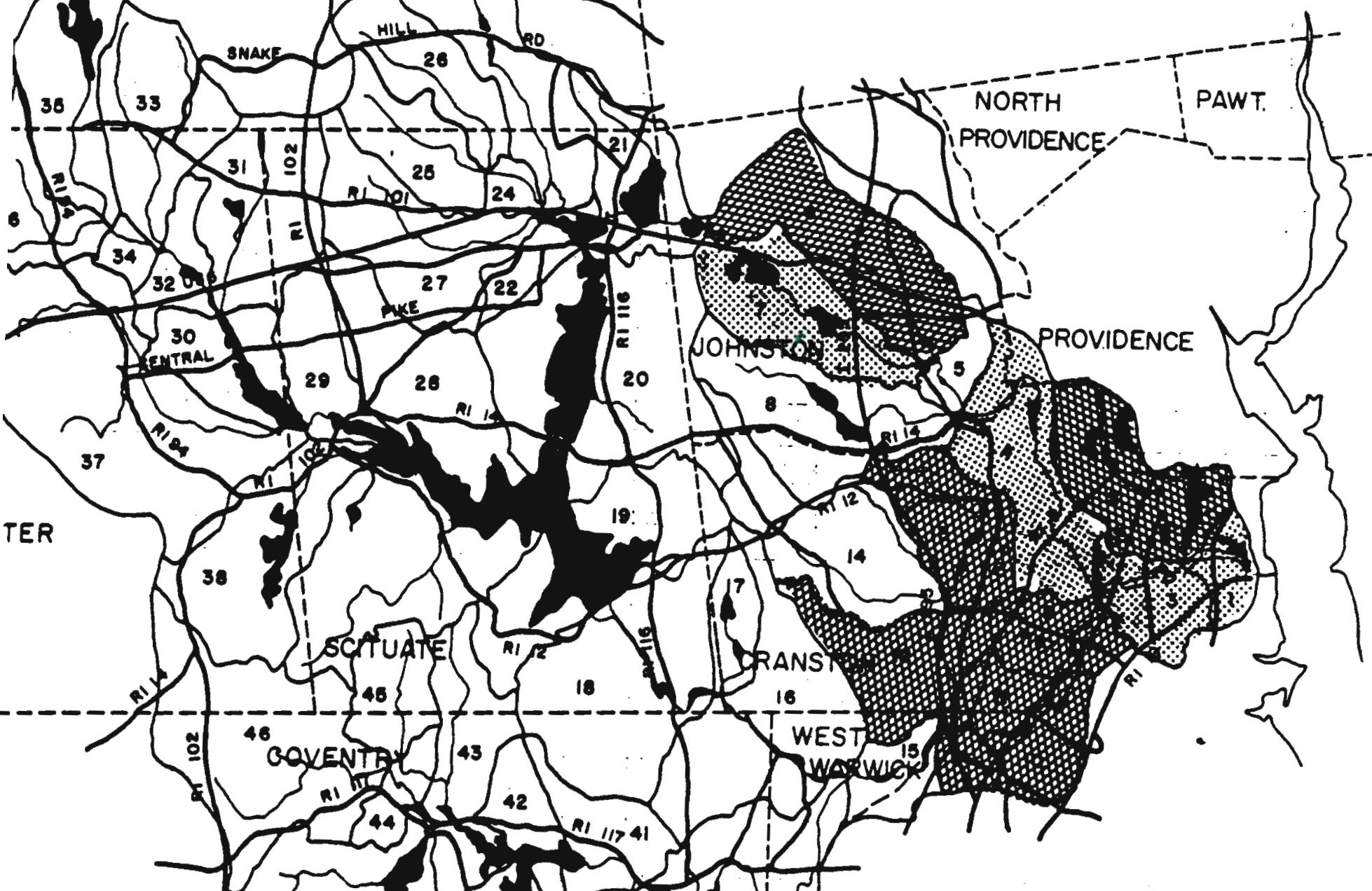
FIGURE 6: PAWTUXET RIVER DRAINAGE BASIN WITH SUBDRAINAGE BASINS SHADED ACCORDING TO THE AVERAGE CALCULATED RUNOFF-BORNE LOADING RATE OF ZINC (LB/ACRE/YR)

\section{GLOCESTER}

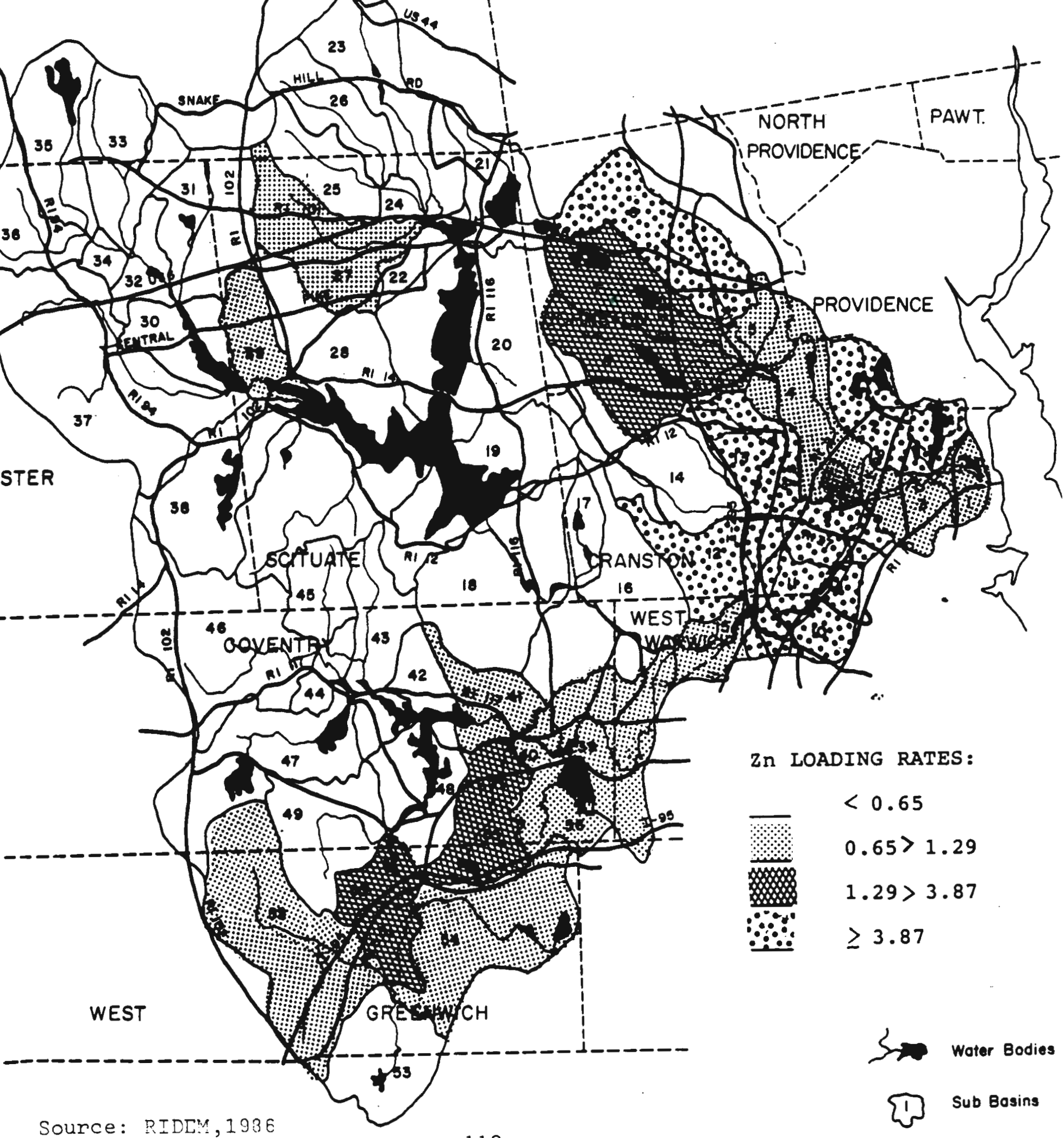


$\begin{array}{llllllllll}A & P & P & E & N & D & I & X & D\end{array}$ 


\section{Developing a small community sewage facility through a municipal authority}

The Pennsylvahia State University College of Agriculture, Extension Service University Park, Pehilisylvanila 


\section{AUTHORS}

Ru Mllhal Subre. Ph.D. Research/Extension Specialist. Cooperative Extension Service

Pefer H. B. Vormon Resource Development Specialist. (inoperative Extension Service

\section{PUBLICATION CONSULTANTS}

Faner D. Dioduo, Chief. Sewage Planning and Traning Services Section. Division of Sewage Falcilities Act Administration. Bureau of Water Quality Mantagement. The Pennsylvania Department of Envirommental Resources

Jas Himes. Assistant Executive Director. Penmyluania Municipal Authoritien Anociaiiiun

itilliom Markus, Counsel, Pennsylsania Mu nicipal Authorities Anociation

Masime Herelling. Asidant Altorney Cent cral. Burcau of Regulatory Counel, The Ponm? Ramia Department of Environmental Reverutes

Willium / Holl. Fesculive Director. PennYhatnia Municipal Authorities Association

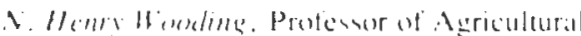
Engencering Extemsion. The Pentrylamat

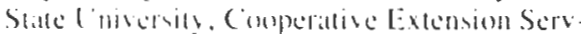
icio

\section{CONTENTS}

\section{TABLES;}

PREFACE I

\author{
(iLOSSARY I
}

\section{INTROI)LCOION}

THE PH.NAST VANA RLRII, SH ACII ICIIIISSIRAIECiY

(ime Factors and Ranges for the On-lon Management Sisem (OLNS Technology $+$

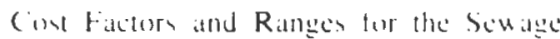
Eltuent Collectum and Treatment Siscem tSE("IS Techmology) \&

Cos factors and Ranges for Combined Technology (CT) 4

COST ESTIMATES FOR A MUNICIPAL. ALTHORITY USING AN OLMS TECH. NOLOCIY. A SECT TECHNOLOGY. OR COMBINED TECHNOLOC'Y' 11

The Municipal Authority II)

Some Impontant Fuctors and costs in Founding a Municipal Authorits II

\section{SLMMARYY ANU RECOMMILNDAIIONS} 14

\section{REFERE:VCES IY}

APPENDIX A 21

Table 1.3 . Simple hudect of luthorits he' fore "standird" tacility is hult 21

Table 14-Sample hudgel of Authority a/e'r

"standard" collection and treatment bacility

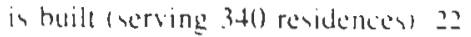

1. Crms referemeing of hey vates and ket re

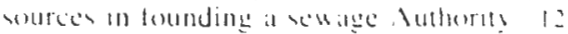

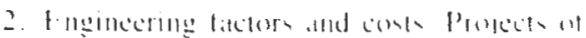

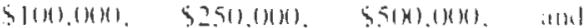
\$1.1401).11010 10 bulal 12

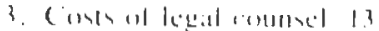

4. Cime of accilunting 13

5. Cos of mandectment it

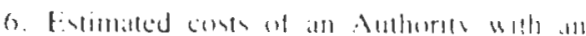

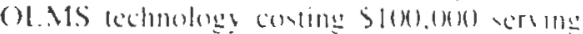
75101011 renidellow 15

7. Extmated come of an duthories with a

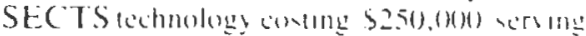
150 residences it

8. Estimated costs of an Authorits wht at

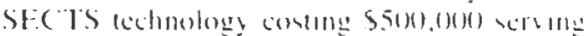
350 revalences to

9 Evematled cont of an Suthorits with a

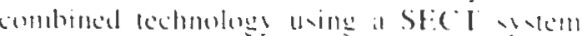

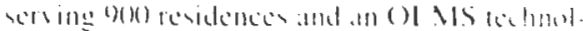

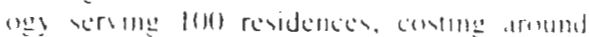

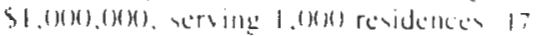

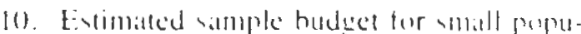
bation ()I.MS and SE( I tacilatic 17

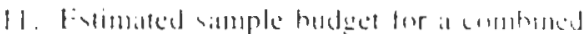

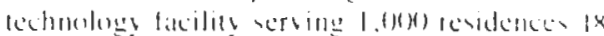

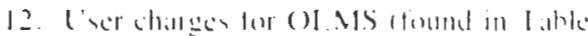
7). Stic (I I ahler 8 and y) and ( I. I I the

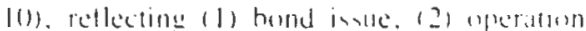
and matntentances and (3) cos thority aftice 19

\section{FIGURES}

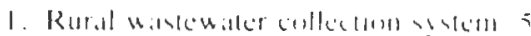

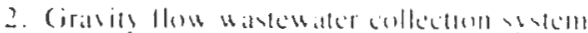
- partiallices 6

3. Suburtace divpual undem?

4. Recirculating and tiller ustem $x$

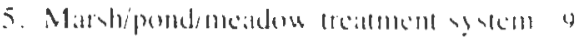

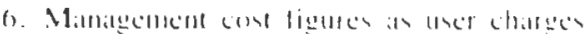

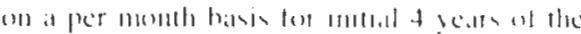

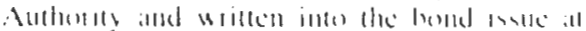

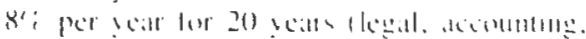
Authorilyollice, and hord councel) 15 


\section{PREFACE}

Our society has always prided itself on being concerned with cleanliness and order. This tradition has given increased attention to the quality of the environment during the past 50 years, with the momentum increasing considerably during the past 20 years.

State and national legislation enacted during this period has stated the commitment to curfailing the pollution of the land, air, and water. In addition, State Departments of Environmental Resources, such as the Pennsyivania Department of Environmental Resources, and the Federal Environmental Protection Agency have been established. Through legislation and these organizations, state and federal governments have increased their capability to provide organization, guidance, and technical and financial assistance to local governments in the effort to improve the quality of the environment.

Local governments face a number of problems, sewage treatment being a major one, in their attempts to curtail pollution at the locial level. The benefit to society is enhanced by the accumulative corrective steps taken by the local people. A major need of small populated communitics is to identify and develop technically and financially feasible scwage treatment systems.

Both the public and private sectors have been searching for ways to meet this need.

This publication focuses on some alternative sewage treatment systems and discusses costs of different systems bascd on size of populations served. The intent is to provide ideas, approaches, and information that may be useful to local governments and their citizens in their efforts to establish appropriate sewage treatment systems. A glossary of terms precedes the text for the convenience of the reader.

\section{GLOSSARY}

ALTERNATIVE SEWAGE COLLECTION AND TREATMENT SYSTEMS. These systems are "alternative to" standard collection and treatment systems which work through gravity flow sewers throughout the entire systens, with occasional lift-pump stations where gravity flow is not possible. and treatment systems involving highly mechanized equipment which are generally labor and energy intensive.

BOND DEBT SERVICE. Bond debt service is that part of the annual indebtedness of a municipality or municipal Authority which is the result of having to pay off a bond issue.

BOND ISSUE. A bond issue is one means of horrowing a large sum of money to pay for costs incurred in producing a facility and paying off that money over a long or extended period of time. There are two forms of bond issue which are of interest in this publication. (1) Since the 1930s municipal bond issues have first been raled by two New York bused firms, and then have been sold on the open market by New York based bonding houses. There are two major results of this nationwide mode of distribution. One result is that the denominations of the bonds have to be at least $\$ 1,000$ and the other is that in order to make the bond issues competitive with other forms of large capital investnents, bonds have to pay a rate of interest competitive with those other fornis of large capital investment. (See publications cited in the reference section of this paper.) (2) The second form of bond issue is a "local" bond issue, issued by the municipality or by the municipal Authority in small denominations, and offers interest rates competitive with what is available at smaller levels of investment. This means that individuals, local banks, and savings and loan organizations can buy these types of bond issues. Both types of bond issues share in conmon the fact that the municipality or the municipal Authority, in either case, becomes legally responsible for levying rates of user charges which at the very minimum cover the annual bond debt service.

BOND ISSUE COUNSEL. A bond issue counsel is a person who arranges for the bond issue. This person makes contact with bond rating firms and firms which float bonds on the open market. It is important to note that the bond counsel fee is generally step-wise. As of 1980 the range is a $\$ 3,000$ charge for any bond issue up to $\$ 25,000$, and a charge of $\$ 15,000$ to $\$ 17,000$ for bond issues from $\$ 25,000$ up to $\$ 7$ million.

CLEAN WATER ACT OF 1977 (PL 95-2 I7). The Clean Water Act is that piece of Federal legislation which, among many other things, through financial incentives encourages the development of alternative and innovative technologics to improve the efficiency and lessen the costs of sewage collection and treatment facilities.
COMBINED TECHNOLOGY (CT). Combined technology is the term coined in this paper for a strategy being considered by the Department of Environmental Resources for putting together different sewage facility technologies or adding a new sewage facility technology in order to meet the sewage treatment needs of an area.

COMMUNITY DEVFI.OPMFNT WORK. COMmUnity development work in this context means involving citizens from the start in the process of planning and producing a sewage facility that will meet their needs. Among other outcomes, good community development work reduces the number of legal battles with the Authority or municipality and hence may ultimately reduce the cost of the facility.

CONSTRUCtion costs. Construction costs include the cost of labor and material involved in producing. in this case, a collection and/or treatment system, or more generally, a sewage facility technology for a given area.

IIEPARIMENT OF ENVIRUNMI:NIAI. RESOURCES (DER). The Pennsylvania Department of Environmental Resources is a cabinet-level agency with a broad legislative mandate to deal with many of Pennsylvania's environ. mental problems. Among the tasks of this Department is carrying out national clean water goals within Pennsylvania. All sewage facility monies released through DER and EPA are for eliminating public health problems and improving the quality of water in Penmsylvania. not for housing development purposes.

DESIGN COSTS. This refers to the cost entailed in designing a facility to meet a community's needs, in particular. tailoring a technology to the soil, slope, housing, and configurational constraints, among many other considerations.

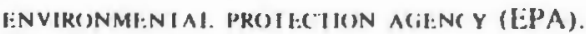
The United States Environmental Protection Agency is the federal organization which has been empowered hy (ongress through the Ex. ecutive Branch to regulate lactors which have an impact on the human environment in the United States.

FACTORS AND COSTS. One way of analyzing any organization is to look at it in terms of the factors involved in producing some facility or service, and these factors have costs associated with them.

FARMER'S HOME ADMINISTRATION (FMHA). FmHA is part of the U.S. Department of Agriculture. Of interest here is the fact that FmHA has monies available on the state level to loan to municipalities interested in devel. oping sewage facilities.

FEAsIBILITy STUdy. A feasibility study is a means of gaining a ballpark estimate of what a sewage facility might cost a municipality. 
GRINDER PUMPS. A grinder pump is designed to grind up all of the solids suspended in liquid from a household, and under pressure, pump this fluid into a collecting line.

LOW-COST TREATMENT SYSTEM. A low-cost treatment system would be low-cost from threc points of view: from the point of vicw of construction, from the point of view of energy used in running the system, and from the point of view of fewer man-hours required to run the system.

MUNICIPAL AUTHORITY. A municipal Authority is an organization whose powers and responsibilities are clearly stated below. It is important to note that a municipal Authority's powers do not exceed those of the municipality which empowers it, but that once created the municipal Authority, while being responsive locally, is like all other forms of local government - a creature of the state subject to regulation by the state.

ON-LOT MANAGEMENT SYSTEM (OLMS). This is a type of technology which has as its general goals creating sound on-lot sewage systems and ensuring that a newly created on-lot sew. age system or existing systems are properly maintained. It of necessity involves a means of enforcing standards of building and maintenance.

OPERATION AND MaINTENANCE COSTS. Generally referred to as $O$ and $M$ costs, these are the costs incurred by the municipality or municipal Authority relating to running the facility and keeping it running. These costs include the costs of a facility operation. costs of service charges, and contingency costs covering the breakdown of machinery, and so forth.

PLANNINC costs. Planning costs in a narrow sense include the costs of securing the financial package necded to finance a projected facility, as well as what are termed preapplication costs.

PRE-APplication. Most existing federal and state agencies require the municipality or Authority to file papers termed pre-application papers. Pre-application is a way of notifying an agency that a municipality is interested in securing funding from that agency and that the municipality, in effect, is aware of the paperwork involved in securing that funding.

PRESSURE PUMPS. A pressure punip is a way of taking liquid runoff from a septic tank or what is termed a primary settling tank and puniping that fluid or liquid, under pressure, into a collector pipe.

PRIMARY SI:TTLING TANKS. A primary settling tank (or a solid retuiner tank or a solid settling tank) is a way of separating solid materials from liquid materials coming out of a residence. Generally, this type of tank has to be pumped periodically to remove the settled sol. ids.
RIGHTS-of-way. This is a legal tern which refers, in this case, to the municipality securing a pathway for laying the pipes it needs to create a collection system for sewage. These rights-of-way generally involve an easement (right of specific use) on the parcel of land from any houscholder or property owner who) is in the pathway of the pipes.

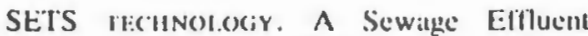
Technology System (SETS) technology is a general way of referring to those technologies which treat sewage effluent somewhere at or near the point of departure of the effluent from the residence, as opposed to having processing or treatment occur only at some remote location. The three examples of SETS technologies considered here are the on-lot management system, the sewage effluent collection and treatment system, and the combined technology system. The on-lot management system treats the effluent near the residence. The Sewage Effluent Collection and Treatment System, or SECTS technology, has an initial processing and/or separation at the source. And the Combined Technology is merely taking one or the other in conjunction and creating a combined technology.

SEWAGE. EFFLUENT COLIECTIOSN ANO TRFATMINT SYSIIM OR SECTS IIEHNOLOCiY. This technology is a form of SETS lechnology in that it involves either separating the solids from the waste watcr at the source, or grinding the eftluent into a liquid form at the source. The effluent can then be pumped through smaller diameter pipes or run on a gravity flow basis through smaller diameter pipes to treatment systems, which cun be labor and encrgy intensive because they are dealing just with the fluid.

STEP 1. Step I refers to Step I monies in the EPA planning process. These monics are planning monics which EPA makes availahle through DER. reimbursing the municipality for 75 percent of the planning costs.

STEP It. Stcp II monies are monics made available again by EPA through DER to help cover the costs of designing a system and will be either 75 percent, if a standard treatment system is designated, or can go as high as 85 percent, if alternative or innovative sewage facility technologies are designed.

STFP III. Step III refers to monies made available for building a sewage facility. EPA will make available. through DER, 75 percent for a standard collection and trcatmuit facility or 85 percent for any part or the whole of a systen which is either alternative or imovative.

USF:R (HARCIYS. A user charge is the cont to the user of a service. A user charge could he paid on a daily, weekly, monthly, or anmual hasis: hut is charged on the bisis of use. With sewage facilities. user charges are generaly figured on a monthly or a bi-monthly basis, based upon the monies needed by the Authority (o) meet its total expenses.

WASII:WAIFR. Wastewater is the liquid part of the elfluent from a residence. 


\section{RRODUCTION}

nes your community have a residen1) sewage disposal problem? (Are ont systems failing? Is there any raw wage in road gutters? Has the Deirtment of Environmental Resources JER) cited the community for pollut$\mathrm{g}$ the soils and waters?)

'o you consider the soil characterisas of your community unsuitable for i-lot systenıs?

to you consider your community too nall to have some form of convenonal collection and treatment system or domestic sewage?

re you looking for a less expensive aly to expand sewage disposal service meet existing needs in your commuity?

f you answered yes to any of these $r$ questions, then your community is ong hundreds of small Pennsylvania amunities that have inadequate sewage tunent systems. Because standard vity how sewers with lift punp stiis and conventional treatment plants beyond the price range of most comnities of 3,500 or under, many such imunities have not seriously organized effort to solve their sewage problems. addition, some of these communities $y$ not be familiar with the municipal thority, which is one organizational ans for planning, financing, designing, Iding, and operating different sorts of lic facilities, including sewage facili.

Dne of the 1977 Clean Water Act's 95-217) major goals is providing ibility in both technology and funding ielp deal with such problems. In Pennvania this goal includes the developnt of a Rural Wastewater Strategy, $h$ the promise of affordable sewage faty technologies for small communi. The critical element in providing ers and other technologies to rurak. mmunities is finunciul fealsibility: specally, the ability of a community to fiice a new sewage disposal system through monthly charges to the user of the service.

These user charges are derived from four factors:

- planning costs

- design costs

- construction costs

- operation and maintenance costs

The first three are generally written into a bond issue which is paid off by a part of the user charges; the remainder of the user charges paying for operation and maintenance of the facility over time.

The complexities of the four factors have influenced the historical evolution of the municipal Authority. A municipal Authority is created by the governing body of a municipality or municipalities. It provides an organizational means of helping the municipality or municipalities handle the day-by-day, year-by-year practical details of planning. producing, financing, running, and maintaining sew. age facilities. The cost associated with providing a facility would be the same whether a municipality (township or borough) or a municipal Authority does the job. The Authority, however, has the advantages of ( $t$ ) improving chances of outside funding. (2) insulating the project from electoral politics, and (3) protecting the municipality from legal suits.

To better understand the entire process of developing a sewage treatment system. and to be able to estimate roughly the final costs that would be reflected in user charges of some specific alternative sew. age facility technologies, we present in this publication the following information:

- Descriptions of three types of sewage facitity technologies and their estimated costs, which as of 1980 may be legally and financially feasible for the small community.

- Present factors and costs related to esfablishing the municipal sewage Authority for each of the three types of technology.

- Provide factors/costs batance sheet for the municipality that night wish to consider the alternatives we are presenting.

\section{THE PENNSYLVANIA RURAL SEWAGE FACILITY STRATEGY}

The Pennsylvania Rural Sewage Facility Strategy is an approach to developing and maintaining improvements in current and alternative sewage treatment systems for the lesser populated rural communities of Pennsylvania .

Residential sewage represents the niajor sewage disposal problem in rural arcas. The alternative technologies in this publication all center around what is called the Sewage Effluent Treatment System or SETS technologies. A SETS technology separates the treatment of residential sewage into two components: first. into the treatment of the sludge which generally accumulates in septic tanks (called septage), and second, the treatment of the wastewater or effluent which is the liquid run-off from the septic tank. The greatest environmental danger comes not from the sludge, but from the effluent. There are three basic types of SETS technology. The first is simply a means of upgrading and maintaining onlot sewage systems. We call this the OnLot Management System (OLMS) technology. The second technology is a Sewage Effluent Collection and Treatment System or SECTS technology, and the third technology is a combination of the two of them, or combined teclinology (CT).

The OLMS technology imolves matking sure that the drainage fields are properly designed or redesigned, built, and maintained. The OLMS technology has the potential to be so inexpensive a wily for at small community to deal with its domestic sewitge problems that debt may be quickly paid off, making it possible for the municipality to handle the problem without lounding an Authority. The critical issue in any case is the management of the OLMS technolngy and the quality of 
its technology and technical assistance.

The SECTS technology is a collection system of small diameter pipes which transmit the effluent from the residential septic tanks to one or more low-cost treatment systems such as the following:

- community conventional subsurface drainage field.

- a recirculating sand filter,

- a contracted connection with another municipality's sewage treatment system,

- a lagoon (with spray irrigation, stream discharge),

- community elevated sand mounds,

- intermittent sand filter.

The effluent can be conveyed to these systems by gravity flow, a grinder pump, or through a low pressure pump system, known as a STEP system for Septic Tank Effluent Pump.

The principle advantages of the SECT system, whether gravity flow or grinder/pressure pump, are that construction costs may be cut dramatically be. cause the collection pipes may be placed in shallow excavations. Low pressure sewers can follow the contour of the land just below the frost line, and can be constructed of small diameter plastic pipes. The effluent treatment systems are designed to be low cost, low energy use, and low labor intensive. The municipality that uses the SECT technologies, particularly if it uses pressure pumps or grinder pumps, has to make sure that these pumps are functioning properly. In short, operation and maintenance of these systems involves adequate management and technical information.

It is important to note that both the OLMS and the SECT technologies have to be carefully constructed, operated, and maintained. Both types of systems have to have the septic tanks pumped out on a regular basis. In addition, the use of the CT (combination of OLMS and SECT technologies) may be the better system for the lesser populated areas with their combination of sparse and cluster developments.

\section{a. Cost Factors and Ranges for the On-Lot Management System (OLMS Technology)}

The OLMS technology is part of a management system to insure that on-lot systems are properly installed, evaluated, permitted, and maintained. Such a technology could also include the capacity to help home owners purchase/finance both individual and community on-lot systems. An OLMS technology managed by a municipal Authority whose powers were conferred by the proper local ordinances could purchase and lease back onlot systems to a home owner.* This approach has particular importance in low income rural areas. On-lot sewage systens are the most common method of disposing and treating residential sewage in rural areas. Financing these is frequently a problem for low income families.

Such a technology would have minimal construction costs. Its major costs could be in the form of:

- salaries for management and field staff,

- securing technical information about soil types and appropriate sewage systems for replacing or improving existing systems that were not functioning properly,

- the initial planning and design of the specific technical system.

It is interesting to note that EPA'scurremt rules and regulations allow monies under its Step III program to be used for the design/construction of on-lot systems. For illustration purposes, the OLMS technology in this publication is figured on the basis of 100 residences sharing management costs, with one quarter of these residences requiring new septic tanks and drainage fields. With current experience suggesting an average cost of septic tank and field at $\$ 3,000$, capital costs at $\$ 75,000 \quad(25$ residences $x$ $\$ 3,000)$, and other equipment costs at $\$ 25,000$, the total cost of $\$ 100,000$ is put into a bond issue

\section{b. Cost Factors and Ranges for the Sewage Efluent Collection and Treatment System (SECTS Tech- nologies)}

With any SECT technology, since property will be owned with some level of indebtedness, and easements will be needed for routing pipes, a municipal Authority may be the first choice of organizational means for local government to deal with these important details (especially eminent domain and easements).

SECT systems use alternative collection and treatment systems. The collection system takes the wastewater from primary settling tanks (generally septic tanks) on residential lots (see Figure 1).

\footnotetext{
*The legal issues involved in the relationship between the municipal Authority and the ownership of the on-lot system are currently being studied and recommendations are being considered.

126
}

That wastewater travels through small diameter plastic pipes to plastic collector pipes, either by gravity flow, or under pressure from a grinder or pressure pump. The grinder pump simply takes household sewage and grinds it to a liquid and pressures it through pipes. Wastewater or ground liquid sewage can flow through these pipes (1) any of a varicly of different wastewater treatnient systems (see Figure 2).

One treatment system is the use of a sub-surface drainage field which could be located in suitable soils or other suitable material near a community. A set of perforated pipes allows the wastewater to be treated by ground filtration and bacterial action, tuming the soils into a useful treatnent system (see Figure 3). Another treatment system that could be used is the recirculating sand filter. Wastewater is purified by being filtered up to eight times through sand, allowing for natural bacterial action to clean the wastewater sufficiently to be discharged into a stream (see Figure 4). An additional alternative treatment system, marsh/pond/meadow treatment system (Figure 5), may be the combination that would be adaptable to the conditions and needs of some communities. These are effective and extremely inexpensive wastewaler treatnent systems requiring mininal labor and electric energy. Other systems may include lagooning and land application through spraying, or other systems of land application.

The sludge in the septic tanks will be pumped according to a maintenance schedule as it would in any on-lot system. The SECT technology costs are estimated on the basis of 75 (1) $2(\%), 250$ (1) 450 , and 500 to 1,000 residences. The collection systems could flow into an alternative treatment system per 75 to 200 residences, meaning an estimated average 1, 3, and 6 treatment systems, roughly. per community costing around $\$ 200.000$. $\$ 500,000$, and $\$ 1,000,000$. respectively.

\section{c. Cost Factors and Ranges for Com- bined Technology}

A third alternative is sinmply an Authority which combines both an OLMS and a SECT technology. Such a conibined Technology (CT) could be used by an Authority to solve the residential eftluent problem. For example, some areas of a township might be best served by a small diameter gravity flow system which is treated by means of, sily, a recirculating sand filter, while others would be hest served by the proper upgrading of an on- 


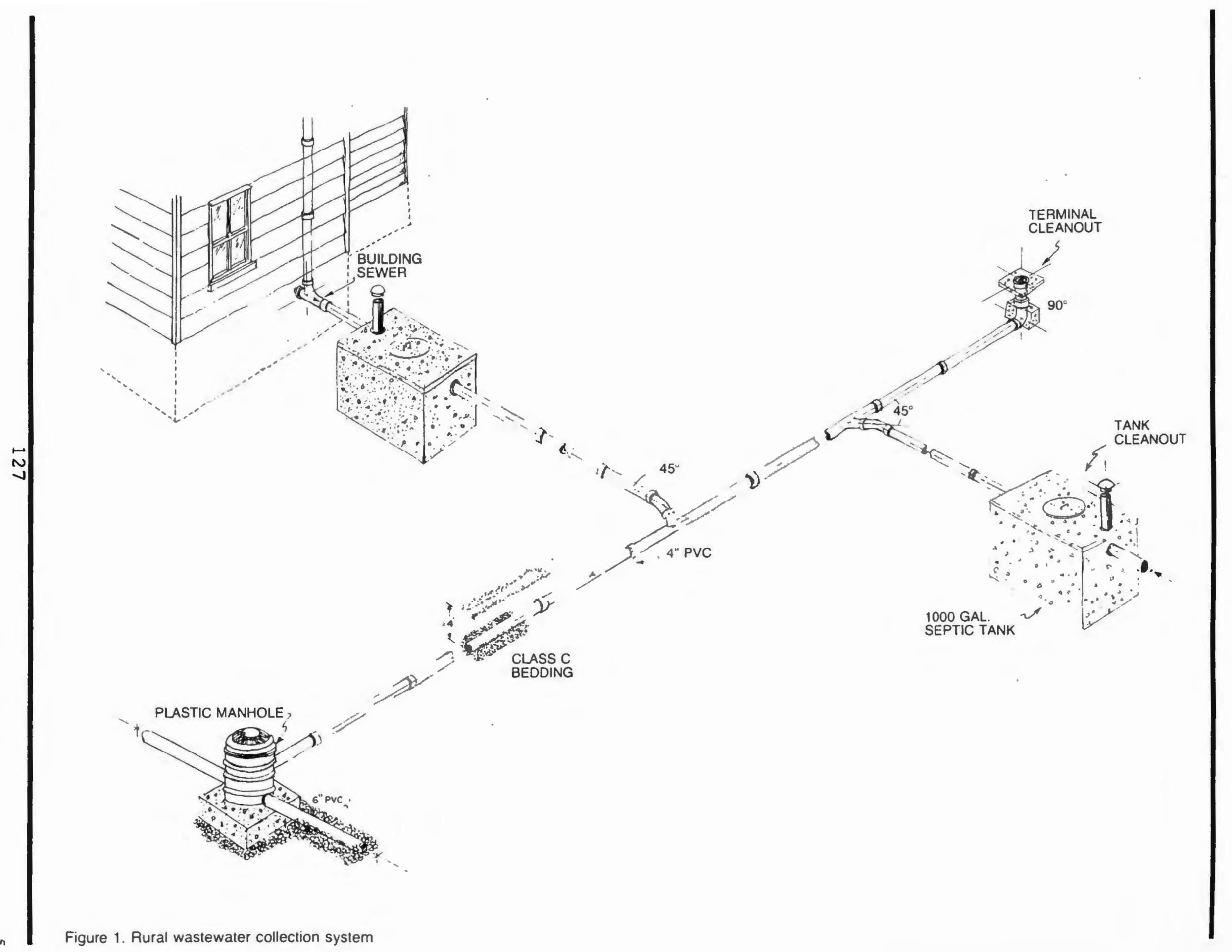




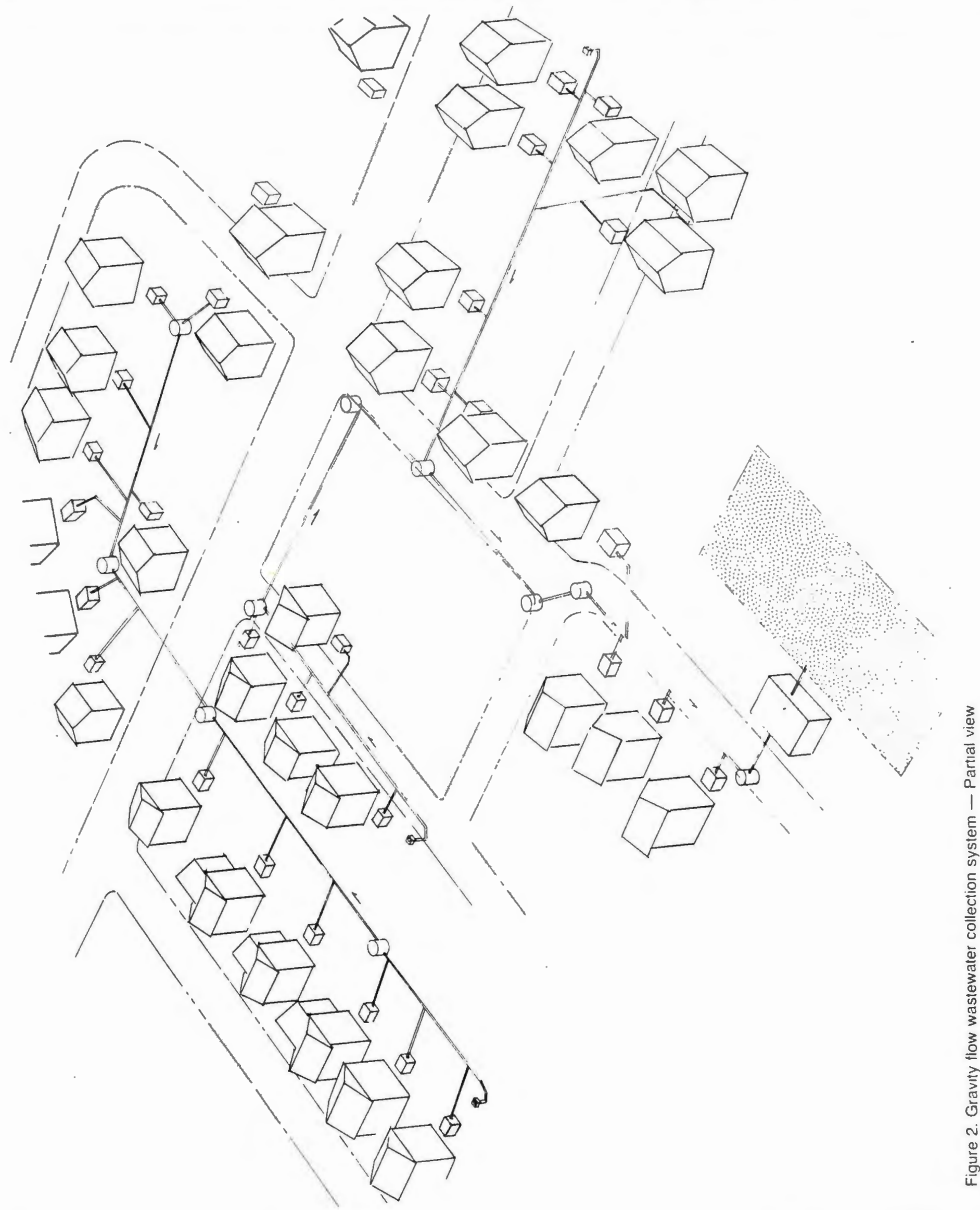




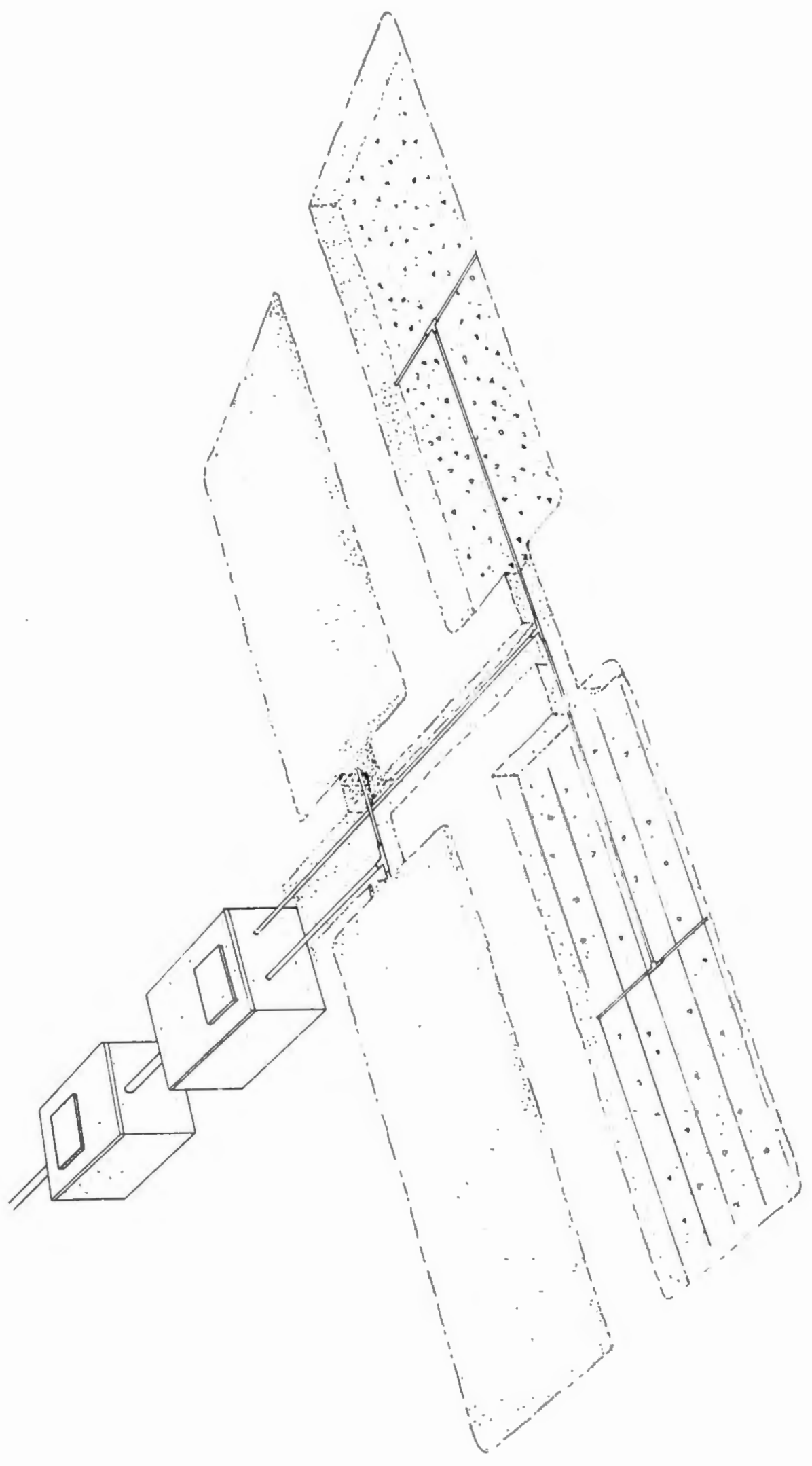




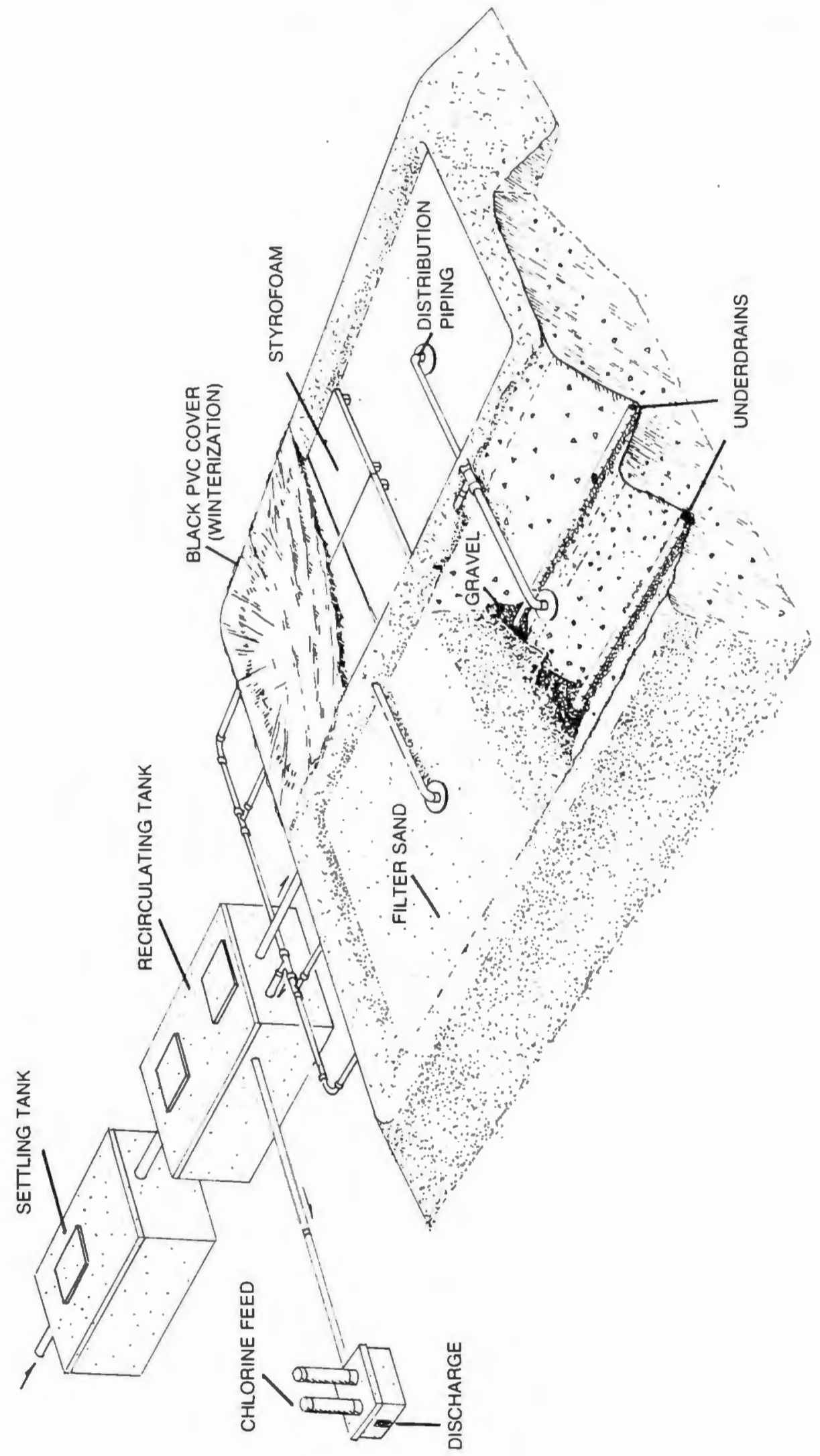




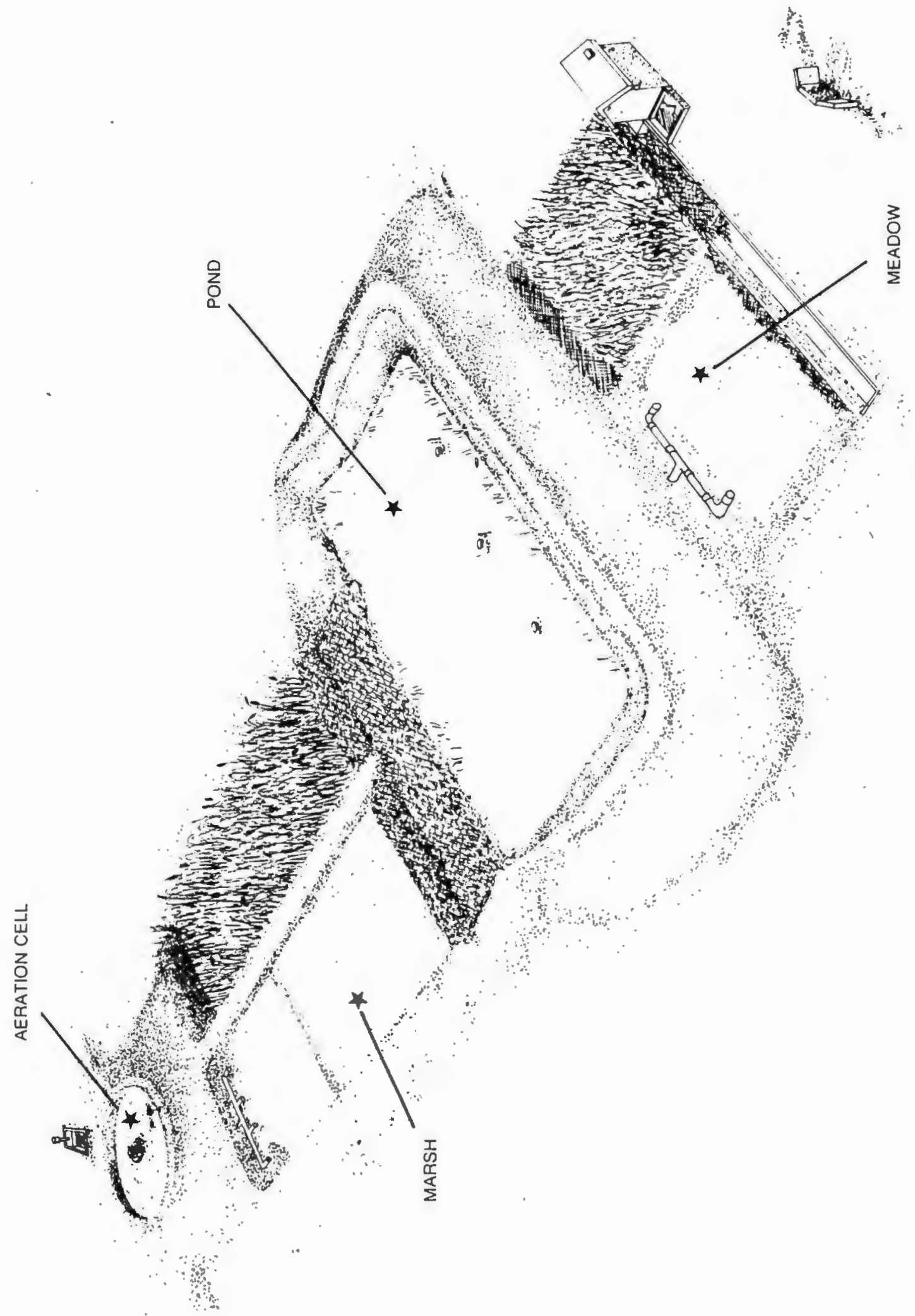


lot system. Principally, this Combined Technology could avoid miles and miles of intercepter and collector sewers which would normally be constructed to join dispersed residential clusters. It is the cost of the collection system and not the treatment system that puts the price tag so high on sewage facilities. Combined Technology is almost infinite in its possibilities. We will later use as an example 900 residences on a SECT system and 100 residences dispersed enough to require an OLMS technology, or $\$ 1,000,000$ in facility costs.

\section{COST ESTIMATES FOR \\ A MUNICIPAL AUTHORITY USING AN OLMS \\ TECHNOLOGY, A SECT \\ TECHNOLOGY, OR COMBINED TECHNOLOGY}

\section{a. The Municipal Authority}

Any township or borough or combination of townships and boroughs may by nutual agreement by law of the Commonwealth of Pennsylvania eslablish a municipal Authority or a joint municipal Authority. Such an organization (referred to as the Authority) may own property and incur debt, and must do both to the end of being a "benefit to the people of the Commonwealth."

Once created according to law by the municipal governing body, the Authority is an autonomous organization in its abilities to use eminent domain and to fix user charges, but it is still a creature of the municipalities and the Commonwealth. For example, the municipal Authority can do only that which the local municipal creating ordinances allow it to do in terms of the type and kind of sewage disposal facility. The state Supreme Court has ruled that a municipal Authority is an agent and instrumentality of the Commonwealth of Pennsylvania, as are all sub-state units of local government.

The following is a listing of the powers and responsibilities of the municipal Authority in Pennsylvania:*

(a) To have an existence for a term of 50 years or as qualified by law; generally the period of time required to pay off the bonded indebtedness should the mandatory limit of 40 years on the bond issue be exceeded.

(b) To sue and to be sued.

*The Pennsylvania Municipality Authorities Act and Related Laws, 1979 (c) To adopt, use, and alter at will, a corporate seal.

(d) To acquire, purchase, hold, lease as lessee, and use any franchise, property, real, personal or mixed, tangible or intangible, or any interest therein, which is 10 say to be able to hold a variety of property.

(e) Acquire by purchase, lease, or otherwise to contract, empower, maintain, repair, and operate a project.

(f) To nlake by-laws for the management and regulation of its operation.

(g) To appoint officers, agencies, employees, and servants; 10 prescribe their duties and to fix their compensation.

(h) To fix, alter, or change, charge and collect rates and other charges in the areas served by its facility in order to pay for the operation of the facility.

(i) To borrow money, make and issue negotiable notes and bonds.

(j) To make contracts.

(k) To make intergovernmental arrangements for obtaining monies and other services.

(l) To have the power of eminent domain. (m) To pledge the revenues or receipts of the Authority.

(n) To carry out activities which will promote the business and general welfare of the Authority to carry out the powers granted to it by acts of the General Assembly of the Conmonwealth.

(o) Contract with any municipality or any public Authority on the terms deemed proper by the Authority for the construction and operation of any project which is partly in this Commonwealth and partly in an adjoining place or state.

(p) To make contracts to furnish project services with non-member municipalities.

(4) To make contracts of insurance.

(r) To charge the property benefiting from being improved by a sewage facility for the cost of construction of any sewer main.

(s) To charge for the cost of any sewer or construction according to the front foot rule.

(t) To charge a tapping on fec whenever the owner of any property connects such property with a sewage system or water muin constructed by the Authority.

(u) Public Utility Commission approval is required before the Authority may institute proper proceedings to construct a facility.

(v) To appoint police officers who shall have the sane rights as any other police officers in the Commonwealth with re spect to the property of the Authority.

Such an Authority used as a means of implementing a sewage facility would 132 have the following life cycle:

1. Founding of Authority as a result of conducting leasibility study - lirst year

2. Planning and ohtaining funding first through fourth year

3. Design - second through fourth year

4. Construction - third through seicenth ycar

5. Operation and maintenance of facility under Authority - fitih through fortieth yeir

6. Payment of deht - filih through forticth yeir

7. Return (1) municipality (ies) (alfer the cancellation of honded indehtedness) - fifth through forticth year

8. A legal 5()-year life eycle is provided in calse the Authority cannot retire its deht in 4 () years

Some Authorities have gone to the planning and design stage and have upent upwards of $\$ 30,000$ to $\$ 50,000$, only to find that they have a design that is (oo) expensive to build, or have had to redesign to obtain outside funding. Others have gone to construction (stage four) only to have delays and intlation at lealst double their estinlated costs, making user charges totally unacceptable to the clients.

Clearly. the critical point is the lirst stage. A good feasibility study will give at least a ball park estimate of the costs of certain types of potentially affordable sewage facility technologies for the small community.

How much does it cost to found an Authority? How nuch will the potentially affordable and workable sewage ficility technologies cost? The answer to the first question indicates what sort of risks the municipality will have to take until they finally ohtain a feasible design. The second will provide some information as to what the lotal cost range might be.

An Authority might he formed hefore the design is done. Founding of an Authority or establishing another appropriate organizational arrangenent indicates a certain degree of seriousness on the part of the municipality or municipalitics. This action should be helptul in obtaining Federal (EPA), Statc, and FmHA funding for planning and design. Also. once the decision hats heen reached 10 solve sewage facility problens, thece are an extraordinary number of day-to-day type details that should be assigned io a specifie person. This person should be an individual from the area, a public-spirited individual who would be willing to work for small compensation with the idea that once the Authority is in full swing. and 
the facility is created, this person's position could improve in both responsibility and income. He or she will be learning on the job, and this is a way of curring costs. The cost of founding an Authority, regardless of the system used, would be about the sanie for the three technologies. The cost of the technologies thenselves (hence design. would vary according to the number of users, the terrain, the regional or local labor costs and a variety of other factors. But we present cost ranges according to a pre-set number of users. Therefore, we first discuss the cost of founding an Authority. Then we will present examples of an OLMS technology, a SECT technology, and a Combined Technology by roughly estimated costs. We then present cost balance sheets which could serve as models (guides indicating estinuated costs incurred) for the municipality interested in founding an Authority and using one or more of thesc tcchnologies, thus helping to determine at least the financial feasibility of the project.*

* Given that an Authority has heen formed, the inlormation that has evolved from a discussion following the approach that we have outlined could be used as part of the pre-application process for Federal and State monies. The three technologies presented above are prohwh/y the least cost alternatives for small communities and should he considered in any kind of pre-application for Federal and State monies.

\section{b. Some Important Factors and Costs in Founding a Municipal Authority}

There are two basic requirenents of any nunicipal Authority: (1) a public interest nust be served: and (2) the facility must pay for itself. The latter means that the revenues from running the facility nust be enough to cover all expenses, such as any renovations, maintenance, and the principal and interest on the debt incurred,**

We noted above in the life cycle of the Authority that the first stage includes founding the Authority and the feasibility study. The second stage includes planning and obtaining outside funding. It is generally within the first and second stage, and at the end of the second stage in particular, that the bond issue is under consideration. The third stage, the design stage, gives information as to what the ultimate costs of the facility would be. The cut off points between stages are not clear, there is some overlapping of each stage by successive stages in the process of organizing. planning, financing, and developing the facility. The cost of the first three stages as well as the actual construction of the system are major factors which are built into the cost of the bonded indebtedness. So, under the general notion of costs in founding a municipal Authority for a sewage facility, we have the following factors:

- the cost of incorporating the authority.

**The Pennsyliania Municipality .fuherities Act and Related l.anss, 1979. pp. 2-4.
- the cost of the feasibility study and pre-application.

- cost of design.

- costs for rights-of-way.

- the cost of the hond issue counsel.

These key factors in founding an Authority can be cross-referenced with key resources needed to carry out each one of those mentioned below:

- costs of engineering.

- costs of legal counsel.

- costs of accounting.

- costs of management.

Table I graphically displays the crossreferencing of the key tasks and the key resources by costs incurred in the first four years of the life of an Authority. It is important to realize that most of the costs. if not all the costs reflected in Table 1, are written into the bond issue. This means that the sum total of expenses which precede the actual construction and use of the ficcility are an important part of the totill costs of producing the facility. Any saving in the first three years can possibly mean lower user fees, for until the Authority can generate revenue, it operate: on money borrowed at interest, and that sum plus the interest is written into the principal of the bond issue.

An efficient way to discuss the cost factors from incorporation of the Authority to the design and bond issue* is to

* The cont factor estimales are derived from calse studies we conducted of the five seuage Authorilies incorporated in Pennoylsania during the perind 1972 to 1979).

Table 1: Cross referencing of key stages and key resources in founding a sewage Authority.

\section{STAGES}

Incorporation of

Authority

Feasibility study

Pre-application

Design

Design

Rights-of-way

acquisition

Bond issue

Construction
RESOURCES

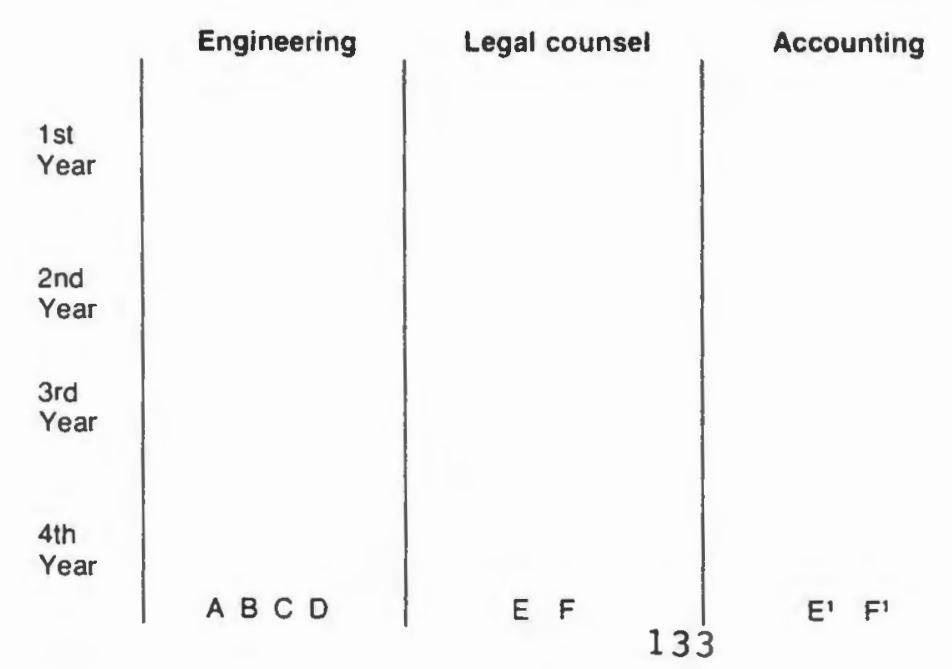

Management costs

exclusive of engineering and bond counsel but including legal, accounting, and management cosis
Management

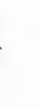


at this matrix in Table 1 from the of view of :

ssts of engineering (labelled A, B. D)

jsts of legal counsel (labelled E, F) osts of accounting (labelled $E^{\prime}, F^{\prime}$ ) asts of management (labelled $G$ )

\section{sits of Engine ering}

neering per se does not enter as a in incorporating the Authority. But reering is clearly a factor in the featy study, pre-application, and deand in the initial stages of running tuthority organization.

I Authorities have a board of directand some have a professional engi(PE) to lake care of running the Auty for up to a three year period until ctual facility is built. Other Authoribring in a manager at the beginning 1 part-time basis and the manager :s with the PE, learning on the job. sme engineers will do a feasibility $y$ and pre-application proposal and to be reimbursed at a later point in . In other siluations, the engineer $\mathrm{ex}$ ; to be paid immediately for these aions, in which case the Authority o) take out a loin wo reimburse the ener. In most cases, the engineer does easibility and/or pre-application work ell as the design work. Engineering ges for design apparently vary from 3 percent of the total costs of a comfacility. For example, the engineercharges, including a feasibility study $\$ 1.3$ million facility were $\$ 60.000$. cting a less than 7 percent charge, e in another case a $\$ 15.5$ million fahad a greater than 7 percent engiing charge for design and all the preication requirements and feasibility $y$. Some of the basic lessons here are the less expensive the technology, rally speaking. the lower should be engineering costs. A rule of thumb is ure of 7 percent of total lacility costs lesign, and 10 percent for design and application work. Another suggestion at the Authority have at least a partmanager employed interacting with rofessional engineer, which seems to lower the 7 percent figure. These iderations are suminarized in Table Engineering Factors and Costs.

\section{Costs of Legal Counsel}

important to realize that municipal citors are usually held on a retainer 10 uruilable for legal needs, and that this iner does not generally include costs performing legal services such as in-

Table 2: Engineering factors and costs:

Projects of $\$ 100,000, \$ 250,000, \$ 500,000$, and $\$ 1,000,000$.

\section{Engineering}

Incorporation of

Authority

Feasibility study

1st

Year

Pre-application

Design

\section{2nd}

Engineering costs are estimated on the basis of the following percentages of the cost of the sewage facility: $7 \%$ for design, $10 \%$ for design and pre-application (10\% figure is the number indicated by $\left.{ }^{*}\right)$.

\section{Design}

Rights-of-way 3rd

acquisition Year

Bond issue

Construction

\section{4th}

Year

\begin{tabular}{|c|c|c|c|}
\hline \multicolumn{4}{|c|}{ COST SUMMARY } \\
\hline$\$ 100.000$ & $\$ 250,000$ & $\$ 500,000$ & $\$ 1.000 .000$ \\
\hline 7,000 & 17.500 & 35,000 & 70.000 \\
\hline $10,000^{\circ}$ & $25.000^{\circ}$ & $50,000^{\circ}$ & $100.000^{\circ}$ \\
\hline $\begin{array}{c}3.000 \\
\mathrm{~A}\end{array}$ & $\begin{array}{c}7.500 \\
B\end{array}$ & $\begin{array}{c}15.000 \\
C\end{array}$ & $\begin{array}{c}30.000 \\
D\end{array}$ \\
\hline
\end{tabular}

coporation or ordinance writing.

The basic costs of incorporating an Authority in terns of a lawyer doing the paperwork are around $\$ 200$. If the potential board happens to include a lawyer. she/he might do it free of charge. In the cases we examined, costs varica from no charge to as high as $\$ 750$.

It is possible that there could he al law suit filed immediately by a citizen challenging the formation of a sewer Authority. These suits have heen hnown (o) run as high as $\$ 6,000$. Also, an Authority can be formed under pressure from the state and the municipal Authority might consider this unjust and choose to sue the state. These suits have heen known to run as high as $\$ 35.000$ to $\$ 40,000$ in legal costs. Though suits are not a common practice with the establishment of every Authority, nevertheless they do occur on occasion.

Legal costs generally do not figure into the feasibility study. pre-application, or the design costs. However, when the design has been created and rights-of-way have heen declared, it is possible that suits may be brought by citizens against the Authority with regard to the right-ofway. These, by law, can cost a maximum of $\$ 500$ per suit. A citizen could also claim an equity suit against the Authority. for the citizen might claim that she/he is not getting enough money for the disturhance of their land. These suits have run around $\$ 5,0(0)$ in legal costs.

In addition, if a new ordinance has 10 he written to enpower the Authority to employ a certain type of technology, the ordinance can run around $\$ .375$.

These eonsiderations are reflected in Table 3: Costs of Legal Counsel.

Legal counsel is generally retained by the Authority or through one of the memher municipalities. The basic lesson we learned is that good communications (sometines thought of as good community development work) with the potential users of the facility during the discussion. planning. and development stages are necessary to avoid legal suits, thus kecping the eosts of these, 100 . Irom heing wrillen into the bond issue. It is also cont saving if a lawyer volunteers his or her services.

\section{Costs of Accouming}

The accountant figures in the incorporattion of the Authority in setting up the hilsic financial structure for the Authority. These charges have run from \$150) 10 $\$ 300$.

An Authority hats a required andit. These audit charges have ranged from $\$ 300(0) \$ 1.200$ a year. When the Author- 
Incorporation of Authority

Feasibility study

Pre-application

\section{Design}

2nd

Year

Design

Rights-of-way acquisition

Bond issue

Construction

Ist
Year

3rd

Year

\section{Legal counsel}

Incorporation $\$ 200$ to $\$ 750$

Suit against founding Authority

$\$ 5,000$ to $\$ 7,000$

Suit filed by municipality against state

$\$ 35,000$ to $\$ 40,000$

$\$ 700$ retainer fee

$\$ 700$ retainer fee

Right-of-way sult $\$ 500$ maximum per

Equity suit if contested, $\$ 5,000$

4th

Year

$\$ 700$ retainer fee

Few legal issues

Many legal issues

$\begin{array}{cc}\$ 2,300 & \$ 14,150 \\ E & F\end{array}$

$\$ 11,850$ difference ity has any sort of trust indenture, which is to say when they owe money to a bank. an audit is required. The audit charges for an ongoing Authority as of 1980 have been recorded at about $\$ 750$ a year.

As with engineering and legill coumsel fees, the fees of the professional accountatst in the Authorities we surveyed have variced for the samc services. And ats lar as we have been able to determine, there are no fixed rates for given services. These rates are determined in negotiation between the Authority and the professional accountant. These considerations are presented in Table 4: Costs of accounting.

\section{Costs of Managememt}

There seems to be a critical dividing point in the life of an Authority. That is, the tine from the perind when the Authority is first formed until the facility is constructed, and from its first being used to generate income to pay off the deht. The first phase has the Authority in a position where it cannot generate revenues from the facility because the facility doesn t exist. Therefore, the Authority is operating on borrowed money. At this point. there are two hasic options. Running the Authority can essentially be turned over to a professional engincer until the facility is constructed (and income generated) or the Authority hoard can hire a nlanager either part-or full-time to oversec all phases of the development of the facility.

Most Authorities have opted for a parttime manager until the facility is constructed and there is an office budget reflecting managenient costs. A saniple pre-facility hudget is given in Table 13 in Appendix $\wedge$. The essential difference hetween the budget reflecting the first phise (pre-lacility) and the budget reflecting the second phase (atter facility is constructed) is that the second phase reflects all of the factors which are involved in running an Authority. which includes the costs of charging the user. Such a hudget is reflected in Table 14 in Appendix $\wedge$ as a sample budget of a conventional sewage facility serving 340 residences (note the annual electric hill and the borough subsidy!).

It is inportant to point out that the bond counsel fee is generally step-wise. That is, we found a $\$ 3.000$ charge for any bond issue up $10 \$ 25,000$ and a charge of $\$ 15.000$ (o) $\$ 17.000$ for hond issues of $\$ 25.0(0)$ up to $\$ 7$ million.

Management considerations are summarized in Table 5: Costs of Manatgement. Figure 6 displays mitnagement 


\begin{tabular}{|c|c|c|c|c|}
\hline & & $\begin{array}{l}\text { Management } \\
\text { (personnel and } \\
\text { office supply) } \\
\text { costs }\end{array}$ & $\begin{array}{l}\text { and ac } \\
\text { excludi } \\
\text { and bo } \\
\text { costs }\end{array}$ & $\begin{array}{l}\text { but } \\
\text { leering } \\
\text { sel }\end{array}$ \\
\hline $\begin{array}{l}\text { Incorporation of } \\
\text { Authority }\end{array}$ & $\begin{array}{l}1 \text { st } \\
\text { Year }\end{array}$ & $\begin{array}{l}\text { No facility } \\
\$ 6,000\end{array}$ & $\begin{array}{l}\text { Minimum } \\
\$ 7.100\end{array}$ & $\begin{array}{r}\text { Maximum } \\
\$ 12,500\end{array}$ \\
\hline Feasibility & & & & \\
\hline Pre-application & & & & \\
\hline Design & & No facility & Minimum & Maximum \\
\hline & $\begin{array}{l}\text { 2nd } \\
\text { Year }\end{array}$ & $\$ 10,000$ & $\$ 11,000$ & $\$ 11,900$ \\
\hline Design & & No facility & Minimum & Maximum \\
\hline $\begin{array}{l}\text { Rights-of-way } \\
\text { acquisition }\end{array}$ & $\begin{array}{l}\text { 3rd } \\
\text { Year }\end{array}$ & $\$ 10,000$ & $\$ 11.900$ & $\begin{array}{r}\$ 11.900 \\
2.500 \\
+\quad 5.000 \\
\end{array}$ \\
\hline & & & $\$ 11,900$ & $\$ 19,400$ \\
\hline Bond issue & & & & \\
\hline Construction & $\begin{array}{l}\text { 4th } \\
\text { Year }\end{array}$ & $\begin{array}{l}\text { Facility } \\
\$ 14,200\end{array}$ & $\begin{array}{l}\text { Minimum } \\
\$ 15.900\end{array}$ & $\begin{array}{r}\text { Maximum } \\
\$ 23.400\end{array}$ \\
\hline & & $\$ 40,200$ & $\begin{array}{l}\text { Minimum } \\
\$ 45,900\end{array}$ & $\begin{array}{r}\text { Maximum } \\
\$ 67,200\end{array}$ \\
\hline
\end{tabular}

costs (the factors being legal, accounting, authority office, and bond counsel) in terms of these costs being paid as part of the bond issue.

\section{User Charges}

The user charges are made up of three components: (1) The bond issue payment must be made by the Authority on an annual basis and is therefore divided up under user charges in that year. These are calculated here on the basis of facility design and construction costs and first 4 years of Authority start-up costs. (2) The costs of the operation and maintenance of the facility. (3) The costs of the operation of the Authority offices.

Tables $6,7,8$, and 9 present the bond issue aspect of user charges in terms of the first phase Authority cost (legal work, accounting, and management), bond counsel, and enginering costs written into the bond issue. We present these in the context of facilities costing $\$ 100,000, \$ 250,000, \$ 500,000$, and $\$ 1,000,000$. Table 6 would enconipass the OLMS system serving users, Tables 7 and 8 a SECT technology, and Table 10 a Combined Technology.

The costs of operation and maintenance of the facilities discussed in Tables
Management, including personnel, office supplies, legal, and accounting but excluding engineering and bond counsel costs

$\$ 45,900$ which will ultimately be reflected in lower user charges by means of:

- Lowering the overall amount of money that has to be borrowed, hence the uverall amount of money on which interest has to be paid. by lowering design and construction costs.

- Lowering the overall operaling and maintenance costs of the lacility.

- Secking maximum outside federal and/or State funding.
$6,7,8$, and 9 can only be roughly estimated on the basis of their low labor and energy uses. Once an OLMS technology is in place, it would require annual inspection and appropriate equipment maintenance. The SECT technology requires inspection of pumps and periodic cleanout of the septic tanks and pipes, as well as some inspection and maintenance work on the waste water treatment system(s) used.

Given the relatively sniall number of residences involved in all but the 1,000 residence Combined Technology, we recommend that the municipality consider that one person be hired to run the office and carry out the inspection work. It is possible to form a cooperative arrangement with the local municipal Sewage Enforcement Officer. Repairs can be done by that person and/or on contract. A saniple budget is provided in Table 10 for the system presented in Tables 6, 7, and 8 and one for Table 9 in Table 11.

Table 12 presents estimated user charges based on factors (1), (2), and (3).

The strategy we employ in this publication to ninimize user charges, while at the same time providing appropriate sewage treatment and environmental protection, is to hold down the overall costs 136 


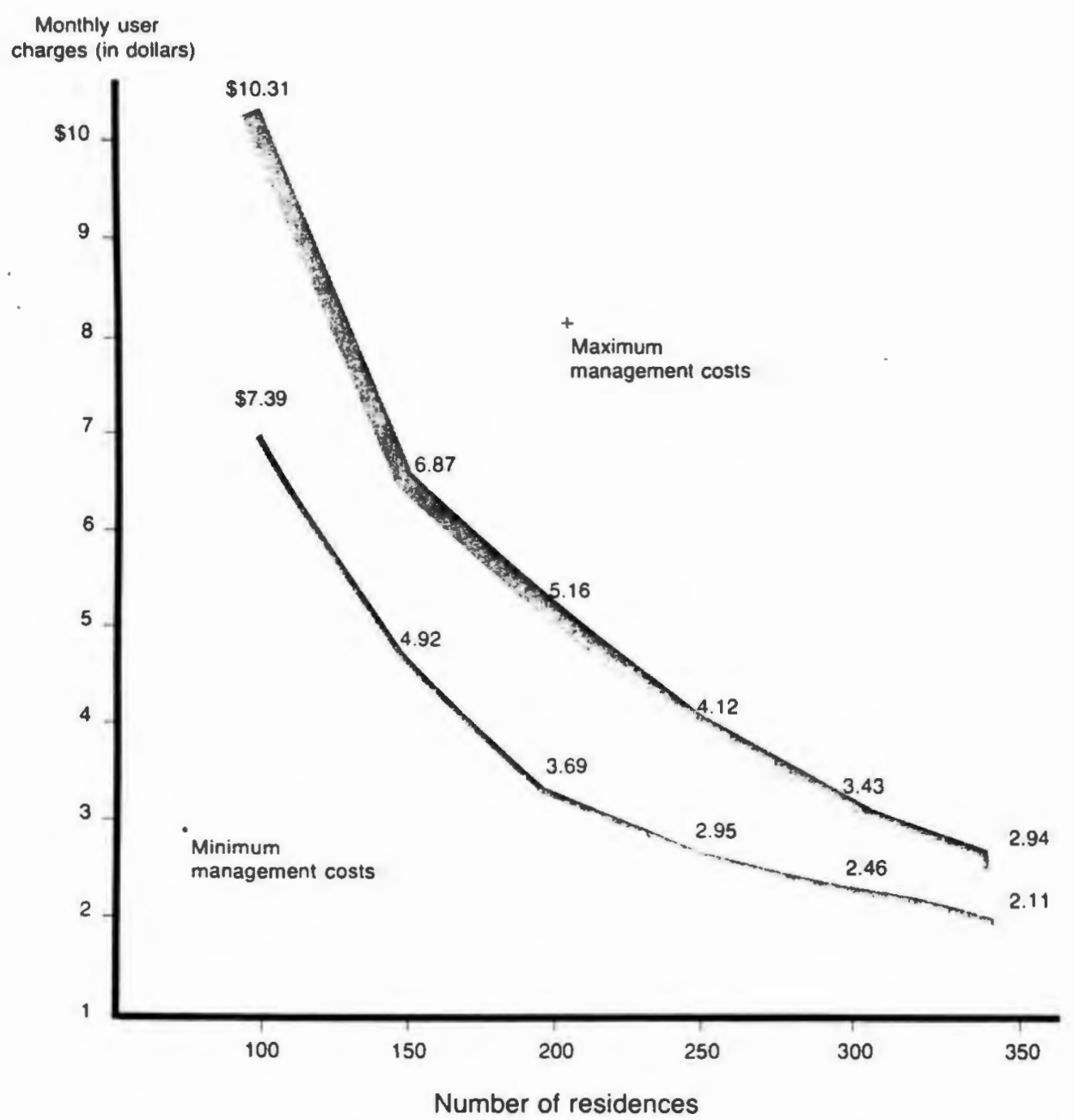

Figure 6: Management cost figures as user charges on a per month basis for initial 4 years of the Authority and written into the bond issue at $8 \%$ per year for 20 years (legal, accounting, Authority otfice, and bond counsel).

- Minimum costs written in - \$68,279 (Table 6) becomes $\$ 177,395$ paid over 20 years.

+ Maximum costs written in $-\$ 95,257$ (Table 8 ) becomes $\$ 247,668$ paid over 20 years.

Table 6: Estimated costs of an Authority with an OLMS technology costing $\$ 100,000$ serving 75 to 100 residences.

1. Assume maximum management costs, first 3 years $(\$ 30,000)$ the money borrowed

at $15 \%(7,100+11,000+11,900)$

with 4th year expense written into bond issue (or bank loan)

$-10,797+14,597+13,685=$

$-$

2. Total of 3 year borrowed money and 4 th year money written into bond issue at 3 rd year

3. Bond counsel fee written into bond issue

Total of management costs written into bond issue

4. Facility costs (local costs) receiving $75 \%$ Step I. $85 \%$ Step II, and

$85 \%$ Step III grant

Step I $\$ 3,000-\$ 2,250$

Step II $\$ 7,000-\$ 5,950$

Step III $\$ 100,000-\$ 85,000$

Total facility costs (local)

5. First 4 year management and facility costs written into bond issue

6. 20 year bonds paying $8 \%$ per year result in annual user charges (100 users)

monthly user charges (excluding operation and maintenance)
$\$ 39,079$

$\$ 14,200$

$\$ 5 \overline{3}, 279$

$\$ 15.000$

$\$ 68,279$

\begin{tabular}{cc}
$\$$ & 750 \\
$\$$ & 1,050 \\
$\$$ & 15,000 \\
\hline$\$$ & 16,800 \\
\multicolumn{2}{c}{$\$ 85,079$} \\
\multicolumn{3}{|}{$\$$} & 110.53 \\
& per year \\
$\$$ & 9.21 \\
& per month
\end{tabular}


Table 7: Estimated costs of an Authority with a SECT technology costing $\$ 250,000$ serving 150 residences.

1. Assume maximum management costs, first 3 years $(\$ 30,000)$ the money borrowed

at $15 \%(7,100+11,900+11,900)$

with 4th year expense written into bond issue (or bank loan)

\begin{tabular}{lrr}
- & $\$ 10,797+14,597+13,685=$ & 39,079 \\
- & & 14,200 \\
- & - & - \\
- & $\$ 33,279$ \\
- & $\$$ & 15,000 \\
- & $\$$ & 68,279 \\
\hline
\end{tabular}

2. Total of 3 year borrowed money and 4 th year money written into bond issue at 3rd year

3. Bond counsel fee written into bond issue

Total of management costs written into bond issue

4. Facility costs (local costs) receiving $75 \%$ Step I, $85 \%$ Step II, and $85 \%$ Step III grant

Step | $\$ 7,500-\$ 5,625$

Step II $\$ 25,000-\$ 21,250$

Step III $\$ 250,000-\$ 212,500$

Total facility costs (local)

5. First 4 year management and facility costs written into bond issue -

6. 20 year bonds paying $8 \%$ per year result in annual user charges -

monthly user charges (excluding operation and maintenance)
$\$ \quad 1,875$

$\$ 3,750$

$\$ 38,500$

$\$ 44,125$

$\$ 112,394$

$\$ \quad 96.50$

per year

$\$ \quad 8.04$

per month

Table 8: Estimated costs of an Authority with a SECT technology costing $\$ 500,000$ serving 350 residences.

1. Assume maximum management costs, first 3 years $(\$ 43,800)$ the money borrowed

at $15 \%(12,500+11,900+19,400)$

with 4th year expense written into bond issue (or bank loan)

$-19,010+15,537+22,310=$

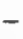

2. Total of 3 year borrowed money and 4 th year money written into bond issue at 3 rd year

3. Bond counsel fee written into bond issue

Total of management costs written into bond issue

4. Facility costs (local costs) receiving $75 \%$ Step I, $85 \%$ Step II, and $85 \%$ Step III grant

Step | $\$ 15,000-\$ 11,250$

Step II $\$ 50,000-\$ 42,500$

Step III $\$ 500,000-\$ 425,000$

Total facility costs (local)

5. Management and facility costs written into bond issue

6. 20 year bonds paying $8 \%$ per year result in annual user charges

monthly user charges (excluding operation and maintenance)
$\$ 56.857$

23,400

$\$ 80.257$

$\$ 15.000$

$\$ 95.257$

$\$ \quad 3.750$

$\$ 7.500$

$\$ 75.000$

$\$ 86.250$

$\$ 181.507$

$\$ \quad 62.41$

per year

$\$ \quad 5.61$

per month 
Table 9: Estimated costs of an Authority with a combined technology using a SECT system serving 900 residences and an OLMS technology serving 100 residences, costing around $\$ 1,000,000$, thus serving 1,000 residences.

1. Assume maximum management costs, first 3 years $(\$ 43,800)$ the money borrowed

at $15 \%(12,500+11,900+19,400)$

with 4 th year expense written into bond issue (or bank loan)

$-19,010+15,537+22,310=$

$-$

2. Total of 3 year borrowed money and 4 th year money written into bond issue at 3rd year

3. Bond counsel fee written into bond issue

Total of management costs written into bond issue

4. Facility costs (local costs) receiving $75 \%$ Step 1, $85 \%$ Step II, and $85 \%$ Step III grant

Step I $\$ 30,000-\$ 22,500$

Step II $\$ 100,000-\$ 85,000$

Step III $\$ 1,000,000-\$ 850,000$

Total facility costs (local)

5. Management and facility costs written into bond issue

6. 20 year bonds paying $8 \%$ per year result in annual user charges

monthly user charges (excluding operation and maintenance)
$\$ 56,857$

23,400

$\$ 80.257$

$\$ 15,000$

$\$ \quad 95,257$

$\$ 7.500$

$\$ 15,000$

$\$ 150,000$

$\$ 172.500$

$\$ 267,757$

$\$ 34.00$

per year

$\$ 2.90$

per month

Table 10: Estimated sample budget for small population OLMS and SECT facilities.

Operating expenses:

1. Plant:

Salaries and wages - facility operator

$\$ 5,000.00$

Materials and supplies

$1,000.00$

Utilities.

$1,000.00$

Repairs

225.00

General expense

80.00

Subtotal..

$7,305.00$

2. Administrative:

Salaries and wages-office.

Office expense

7.900 .00

Advertising

800.00

Professional fees.

50.00

Telephone

1500.00

Repairs.

50.00

Payroll taxes.

000.00

Insurance.

$1,500.00$

General expe

220.00

Subtotal

13.300 .00

Total

$\$ 20,605.00$ 
Table 11: Estimated Sample Budget for a Combined Technology Facility Serving 1,000 Residences.

REVENUE \& INCOME

Annual user charge

$1.000 \times \$ 63.90$

$\$ 63.900 .00$

EXPENDITURES

OPERATION \& MAINTENANCE

Salaries \& wages - Facility operator

Materials \& supplies:

$\begin{array}{lr}\text { Tools } & \$ 50.00 \\ \text { Lab supplies } & 180.00 \\ \text { Chart paper } & 40.00\end{array}$

Chlorine

Chart paper

General expense

Communication expense

Electrical expense

Miscellaneous

ADMINISTRATION

Salaries \& wages - Business manager

Materials \& supplies:

General expense

Advertising \& printing

Legal fees

Auditor fees

Communication expense

Miscellaneous

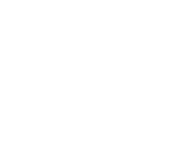

40.00

S 9.500 .00

$\$ \quad 270.00$

500.00

50.00

175.00

2.000 .00

200.00

$\$ 12.695 .00$

Postage

$11,000.00$

P.O. Box rent, billings 30.00

Letterheads, etc.

Copier supplies

Ledger sheets, etc.

590.00

190.00

30.00

$\$ 1,290.00$

50.00

55.00

700.00

750.00

250.00

50.00

$\$ 14.145 .00$

Employee benefits \& taxes

Social security taxes

Unemployment compensation

\$ $1,000.000$

250.00

\$ 1.25000

Insurance

Fire

Compensation

Casualty \& liability

$\$ \quad 300.00$

750.00

750.00

$\$ 1.80000$

ADMINISTRATION EXPENSES

$\$ 17.195 .00$

TOTAL EXPENDITURES

DEBT SERVICE

$\$ 29.890 .00$

$\$ 34.000 .00$

TOTAL

$\$ 63.890 .00$ 
Table 12: User Charges for OLMS (found in Table 7), SECT (Tables 8 and 9) and CT (Table 10) Reflecting (1) Bond Issue (2) Operation and Maintenance and (3) Costs of Running Authority Office.

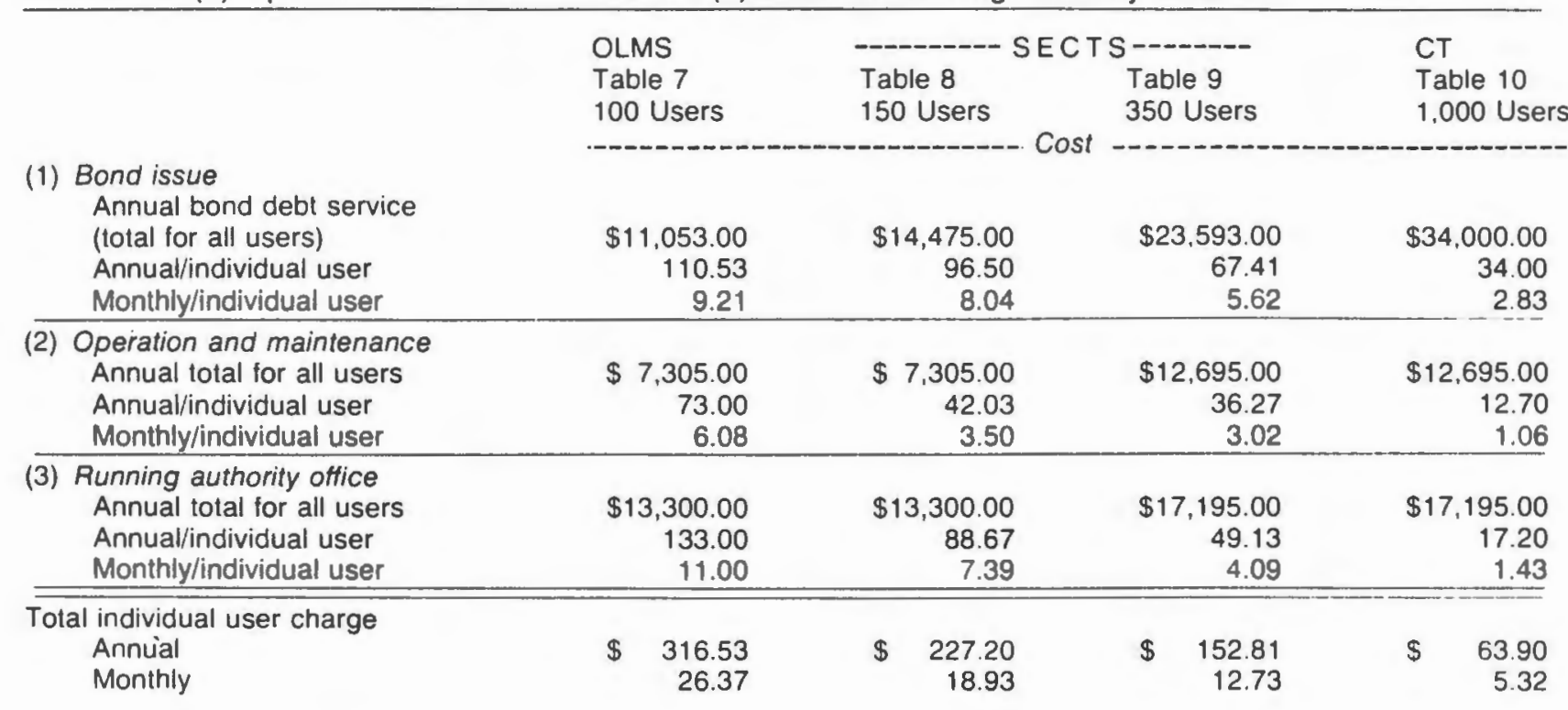

\section{SUMMARY AND} RECOMMENDATIONS

Many townships and horoughs throughout ennsylvania need to improve the collection $\mathrm{nd} /$ or treatment of sewage. The challenge in neeting this need is to develop a system that vill provide appropriate pollution protection or the air, land, and water at lowest cost to the sers. Municipalities facing this problem are ncouraged to:

- Identify the geographic areal and the townhips and/or boroughs in which the problem vists.

- Identify the number and types (domestic, ommercial, etc.) of users to be served.

. Consider alternative management systems, e.:

a. On-tot management systems (OLMS).

b. Sewage effluent collection and treatment system (SECTS).

c. A combination of the technologies used in the two systems (CT).

Determine and establish the organizational rrangement that will meet the need: i.e.:

a. A department within the local government.

b. A municipal Authority.

c. A joint municipal Authority that includes the participating municipalitics.

d. Use the material in this publication as a guide in establishing the system and organizational arrangement to provide the service.

Determine the appropriate means of fiIancing the facility, c.g.:

a. Local bond issuc. small denomination (or in combination with medium and large denominations) with a local or regional sale of bonds.

b. Local issue, large denomination, with sales through national bonding markets.

\section{REFERENCES}

\section{Bond lssue}

Issuing Municipal Bonds: A Primer for Locial Officials.

1979, Andrea Lubov, U.S. Department of Agriculture, Economics, Statistics, and Cooperatives Service, in cooperation with the Department of Agricultural and Applied Economics. University of Minnesota.

This manual gives an olerview of how bonds of small local governments are issued. underwritten, marketed. and serviced. The manual distinguishes the different types of honds, discusses the appropriateness of each sype for different purposes. und illustrates the effect of differen repayment structures on interest costs. The types of documents that a community must prepare in connection with a bond offering are also discussed.

Municipal Bond Ratings.

1979, D.G. Schlosser. Information Services Center, Department of Community Affairs, Conimonwealth of Pennsylvania.

In response (o) numerous inquiries from local governments concerning municipal bond rating criteria and standards, this brochure gives local municipalities more information on hond ratings and how they are determined. Copies aruilable from Deparment of Community. Affuirs.
2. Factor/Cost Approuch on Public Facilities (pioneered by Gerald A. Docksen).

Ecomonics of Water Delivery Systems in Rural Oklahoma.

1979. H. L. Goodwin, Gerald A. Doeksen, and James R. Nelson, Agricultural Experiment Station, Oklahoma State University. Bulletin B-745.

An exumple of pioneer work in the factorlcost approach to public facilities which inspired this publications.

\section{The municipal Authority.}

Municipal Authorities Board Members. Characteristics and Qualifications.

1974. Walter H. Nichoff. The Pennsylvania Municipal Authorities Association. Institute of Regional Affairs. Wilkes College. Wilkes-Barre. PA 18708. Available from the publisher.

Orgatnising a Municipal Authority in Pennsylvanial.

1972. Pennsylvania Municipal Authoritics Association, Harrisburg, PA 17110.

This booklet gives a brief summary about organising a municipal Auhority. It could also serve as a "refresher course" for veleran Authority members or as a guide for others who desire e'ssential information ahoua municipal Auhorities. Availuble from the publisher. 
Pennsylvania Municipal Authorities. Current, William H. Markus and Peter H. B. Norton, The Pennsylvania State University, College of Agriculture, Cooperative Extension Service, University Park, PA 16802.

Provides a history and comprehensive understanding of the municipal $A$ thority in Pennisylvania. Copy available through County Cooperative $E x$ tension Office.

The Pennsylvania Municipality Authorities Act and Related Laws.

1979, compiled by the Pennsylvania Municipal Authorities Association, Harrisburg, PA 17110.

It is the purpose of this publication to enable persons interested in the law relating to municipal Authorities in the Commonuealth of Pennsylvania to 10 cate readily all statutory material. The Pennsylvania Municipality Authorities ACl of 1945, P.L. 382 has been printed with all amendments to the legislative session of 1978. The original Municipality Authorities Act was the Act of 1935, P.L. 463. There were numerous amendments to this Act and it was subsequently reenacted and is now the $A$ ct of 1945, P.L. 382, P.S. 301, el seq. Amendments were introduced at sessions of the Legislature subsequent to 1945. These are all embodied in the Act printed herewith. Available from the publisher.

\section{Sinall Community Sewage Facilities}

Alternative Methods of Effluent Disposal for On-Lot Home Sewage Systems, Special Circular 214.
Current, N. Henry Wooding, Cooperative Extension Service, College of Agriculture. The Pennsylvania State University, University Park, PA 16802.

Provides basic information about onlot systems, including perc tests, aerobic and anacobolic senage-tratmont tanks, and various types of drainage fields. Copy available through County Cooperative Extension Office.

Home Sewage Disposal, Special Circular 212.

Current, N. Henry Wooding, Cooperative Extension Service, College of Agriculture, The Pennsylvania State University, University Park, PA 16802.

Covers elevated sand mound, sandlined beds and trenches, aerobic treatment standards, oversized absorption areas, effluent distribution systems. shallow placement absorption systems, a matrix for alternative systems, and soil groups. Copy anailable through Commty Cooperative Extension Office.

Innovative and Alternative Technology Assessment Manual.

1979, United States Environmental Protection Agency, Municipal Environmental Research Laboratory. Office of Research and Development, U.S. Environmental Protection Agency, Cincinnati, OH 45268.

Being circulated for review and comment, this mamual contains information about over 100 alternative and innovative sewage facility technologies to be useful in the plamning stage where performance and costs are of interest.
Specifically it provides (/) description. (2) techmology status. . (3) applications. (4) limiations. (5) typical equipmem. (6) performance. (7) design criteria, (8) unit process reliability. (9) cmironmental impuct, (I0) a flow diagram. (II) energy motes, and (I2) costs. Copices are aluiluble by writing to the cited address. In the near funure. a revisced manual based on the reactions to the whove will be aruilable.

Small Wastewater Systems, Alternative Sistems for Smull Communities and Rural Areas.

1980, United States Envirommental Protection Agency, Office of Water. Program Operations, Washington. D.C. 20460 .

A useful summary in diagram form of alternative systems, arailahle at the above address.

Technical Manual for Sewage Entorcement Officers.

1977, Local Government Research Comporation. The Pennsylvania Department of Environmental Resources. Harrishurg, PA. 17120

Pronides casily undersenol and useliul technical information hasic an anderstanding the slope and soil conditions and their relationship as a sewase system. County DER Office has copies. 
I. Disbursements:

1. Execulive director

$\$ 2.00000$

2. Board of directors expenses 1.200 .00

3. Phone 30000

4. Copier 132.00

5. Audit .50000

6. Office rent 25000

7. Postage 60.00

8. Office supplies 10000

9. Professional fees 1.100 .00 Total

S 5.642 .00

2nd to 4th Year

11. Operating Expenses:

1. Salaries and wages

S 3.186 .00

2. Plant supplies.

144.00

3. Insurance 300.00

4. Dues and subscriptions 5000

5. Office expense 412.00

6. Professional fees 300.00

7. Telephone 276.00

8. Taxes:

Social security

193.00 Unemployment

37.00

9. Miscellaneous .4500 Total 
Table 14: Sample budget of Authority after "standard" collection and treatment facility is built (serving 340 residences).

\section{REVENUE}

Sewer user charges

Tap-on fees

State subsidy

Borough subsidy

TOTAL REVENUE

\section{EXPENDITURES:}

OPERATION \& MAINTENANCE

Salaries \& wages - Plant operator

Salaries \& wages - Asst. plant operator Materials \& supplies:

\section{Chlorine}

General expense

Communication expense

Electrical expense

Maintenance \& repair

Sludge removal \& disposal

Fuel-heat-water

Miscellaneous

\section{ADMINISTRATION}

Salaries \& wages - Business manager Materials \& supplies:

General expense

Advertising \& printing

Legal fees

Engineering fees

Auditor fees

Communication expense

Miscellaneous

Postage
P.O. Box rent, billıngs
Letterheads, etc
Copier supplies
Ledger sheets, etc.
Tools

Oil \& grease

Lab supplies

Chart paper
$\$ 5000$

200.00

180.00

35.00

$\$ 23000$

3000

19000

9000

30.00
$\$ 49.937 .00$

3.30000

5.10000

12.00000

$\$ 70.337 .00$

$\$ 9.00000$

1.00000

$\$ \quad 465.00$

500.00

50.00

175.00

12.000 .00

500.00

600.00

10000

200.00

$\$ 24.50000$

$\$ 7.28000$

570.00

50.00

55.00

700.00

1.20000

75000

25000

50.00

$\$ 10.905 .00$

$\$ 998.00$

23600

$\$ 1.234 .00$

Unemployment compensation

INSURANCE

Fire

Compensation

Casualty \& liability

Bonding

$\$ 300.00$

75000

750.00

95.00

S 1.895 .00

$\$ 38.524 .00$

$\$ 31.71300$

$\$ 70.337 .00$ 